\title{
Dietary Polyphenol Supplementation in Food Producing Animals: Effects on the Quality of Derived Products
}

\author{
Valentina Serra ${ }^{1, *(\mathbb{D}, \text { Giancarlo Salvatori }}{ }^{2}$ and Grazia Pastorelli ${ }^{1, *}$ \\ 1 Department of Veterinary Medicine, University of Milano, Via dell'Università 6, 26900 Lodi, Italy \\ 2 Department of Medicine and Sciences for Health "V. Tiberio", University of Molise, \\ Via Francesco De Sanctis 1, 86100 Campobasso, Italy; salvator@unimol.it \\ * Correspondence: valentina.serra@unimi.it (V.S.); grazia.pastorelli@unimi.it (G.P.); \\ Tel.: +39-0250-334-576 (V.S. \& G.P.)
}

check for updates

Citation: Serra, V.; Salvatori, G.; Pastorelli, G. Dietary Polyphenol Supplementation in Food Producing Animals: Effects on the Quality of Derived Products. Animals 2021, 11, 401. https://doi.org/10.3390/ ani11020401

Academic Editors: Susana Chamorro and Carlos Romero

Received: 23 December 2020

Accepted: 2 February 2021

Published: 5 February 2021

Publisher's Note: MDPI stays neutral with regard to jurisdictional claims in published maps and institutional affiliations.

Copyright: (c) 2021 by the authors. Licensee MDPI, Basel, Switzerland. This article is an open access article distributed under the terms and conditions of the Creative Commons Attribution (CC BY) license (https:// creativecommons.org/licenses/by/ $4.0 /)$.
Simple Summary: Polyphenols are secondary plant metabolites mainly known for their antioxidant properties. Their use as feed additives in the nutrition of farm animals is becoming increasingly popular as they are particularly exposed to oxidative stress which is reflected in a lipoperoxidation of the final product. For this reason, it is essential to preserve the quality and the safety of meat and milk products by attenuating oxidative deterioration. Moreover, polyphenols present the advantage of being more acceptable to the consumers than synthetic counterparts, as they are considered to be "non-toxic". The present review presents an overview of several studies focused on the dietary supplementation of polyphenols to monogastric and ruminants, as well as their direct addition to meat and dairy products, with particular emphasis on their antioxidant effects on the final product.

Abstract: The growing interest in producing healthier animal products with a higher ratio of polyunsaturated to saturated fatty acids, is associated with an increase in lipoperoxidation. For this reason, it is essential to attenuate oxidative deterioration in the derived products. Natural antioxidants such as polyphenols represent a good candidate in this respect. The first part of the review highlights the occurrence, bioavailability, and the role of polyphenols in food-producing animals that, especially in intensive systems, are exposed to stressful situations in which oxidation plays a crucial role. The second part offers an overview of the effects of polyphenols either supplemented to the diet of monogastric and ruminants or added directly to meat and dairy products on the physicochemical and sensorial properties of the product. From this review emerges that polyphenols play an important, though not always clear, role in the quality of meat and meat products, milk and dairy products. It cannot be ruled out that different compounds or amounts of polyphenols may lead to different results. However, the inclusion of agro-industrial by-products rich in polyphenols, in animal feed, represents an innovative and alternative source of antioxidants as well as being useful in reducing environmental and economic impact.

Keywords: polyphenols; antioxidants; feed additives; food-producing animals; pig; poultry; ruminants; animal product quality

\section{Introduction}

There is a growing interest in producing healthier animal products with a higher ratio of polyunsaturated (PUFA) to saturated fatty acids by modulation of animal's diet. This nutritional strategy has been associated with an increase in lipoperoxidation. It is essential to preserve the quality and the safety of meat and dairy products by attenuating oxidative deterioration. Antioxidant molecules can be added to feed or introduced directly into the final product to control and reduce the beginning of the oxidative process. Recently, the interest of food processing industries in the use of natural antioxidants rather than synthetic counterparts was increased, for either low environmental impact or economic reasons [1]. 
Furthermore, natural antioxidants represent a good candidate in this respect because they are also well accepted by the consumers since they are considered safe. In the last decade, there has been a growing interest in supplementing animal feeds with plant antioxidant to boost the nutritional value of meat for consumers' health benefits $[2,3]$. For these reasons the calls to use botanical-based feed additives due to their claimed antioxidant activity and beneficial effects on farm animal performance and animal product quality is increasing.

Based on the above, this review aims to briefly summarize the description of polyphenols, and plant or plant extract rich in polyphenols (e.g., rosemary, grape by-products, citrus by-products) that are increasingly used as feed additives in the diet of monogastric and ruminants to mitigate damages caused by oxidative stress to which they are subjected. Moreover, this review offers an overview of the effects of polyphenols when applied in meat and dairy products, discussing the form in which they are used and their influence on the physicochemical and sensorial properties of the final products.

\section{Classification and Structure of Polyphenols}

The polyphenols comprise a large group of more than 8000 different compounds with the phenolic hydroxyl groups being the common structural feature. In nature, polyphenols are usually found conjugated to sugars and organic acids, and, according to the number of aromatic rings and their binding affinity for different compounds, can be divided into three classes, flavonoids, non-flavonoids, and tannins [4] (Figure 1). Flavonoids comprise the largest group of polyphenols with more than 4000 compounds identified and share as a common structure two benzene rings connected by three carbon atoms forming an oxygenated heterocycle $[5,6]$. Based on the type of heterocycle, the following flavonoid subclasses can be distinguished: flavonols, flavones, flavanols, flavanones, anthocyanins, and isoflavones [7]. The group of flavonoids is responsible for the red, blue, and yellow colouration of plants. They are found mainly in onions, leeks, soybeans, berries, and tea $[5,8]$. The group of non-flavonoid-polyphenols comprises phenolic acids (cinnamic acid, such as ferulic, caffeic, coumaric, and sinapic acid, and the less abundant hydroxyl benzoic acids, such as gallic and vanillic acid), lignans (e.g., secoisolariciresinol, pinoresinol, syringaresinoland), and stilbenes (e.g., resveratrol). Tannins, commonly referred to as tannic acid, are water-soluble polyphenols that are present in many plant foods. They have been reported to be responsible for decreases in feed intake, growth rate, feed efficiency, net metabolizable energy, and protein digestibility in livestock animals [9].

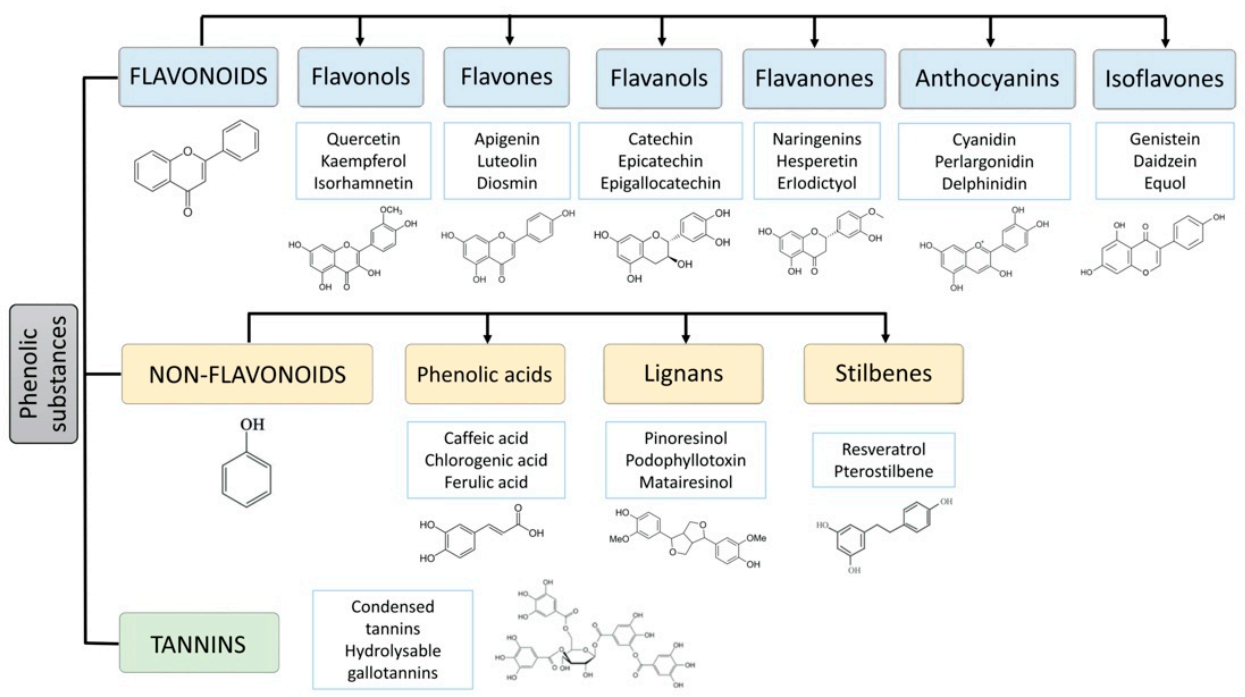

Figure 1. Main classes of polyphenols: flavonoids, non-flavonoids (phenolic acids, lignans, stilbenes) and tannins. 


\section{The Distribution of Polyphenols in Nature}

Polyphenols are commonly found in almost all plants, occurring in various parts of them, such as roots, leaves, flowers, fruit, and seeds, and they protect plants against pests and UV radiation [10,11]. Their distribution at the tissue level is not uniform; for example, the outer layers of plants contain higher polyphenol levels than the inner layers or insoluble polyphenolic compounds are associated with the cell wall, whereas soluble ones are found in the cell vacuoles [12]. Furthermore, the concentration and the proportions of polyphenolic compounds in plants are affected by ripeness at the time of harvest, soil type, sun exposure, air temperature and rainfall, processing, and storage [13]. In particular, the concentration of polyphenols in plants decreases with increasing storage time and in presence of high temperatures due to the high susceptibility of polyphenols to oxidation.

Fruits, vegetables, legume seeds, nuts, herbs, cocoa, and tea represent typical polyphenol-rich sources, and for this reason, humans regularly consume these foods [14,15]. The beneficial effects of polyphenols are mainly attributed to their antioxidant properties as they can act as chain breakers or radical scavengers depending on their chemical structures [16].

\subsection{Flavonols}

Flavonols are the most ubiquitous flavonoids in foods, representing, for example, the most abundant class in Vitis vinifera grape berry seeds $[17,18]$. One of the most important flavonols is quercetin, present in fruit and vegetables, which occurs mainly in leaves and the other parts of the plants as aglycones and glycosides. These compounds are identified by the location of the hydroxyl group on the $C$ ring. The associated sugar moiety is very often glucose or rhamnose, but other sugars may also be involved. Other food sources rich in flavonols are onions, leeks, broccoli, and blueberries.

\subsection{Flavones}

From the structural point of view, flavones lack hydroxyl group at the 3-position. This group of flavonoids derives from two flavanones, naringenin and pinocembrin, that are synthesized from the condensation of one molecule of hydroxycinnamoyl-coenzyme A and three molecules of malonyl-coenzyme A. Flavones can be found in all parts of plants, above and below ground, in vegetative and generative organs, such as stem, leaves, buds, bark, heartwood, thorns, roots, rhizomes, flowers, fruit, seeds, and also in root and leaf exudates or resin [19]. The only important edible sources of flavones identified to date are parsley and celery.

\subsection{Flavanols}

Flavanols exist in both the monomer form (catechins) and the polymer form (proanthocyanidins). The richest sources of catechins are chocolate and green tea (an infusion of green tea contains up to $200 \mathrm{mg}$ catechins [20]); moreover, but they can be found in many types of fruit and red wine. Black tea contains fewer monomer flavanols, which are oxidized during "fermentation" (heating) of tea leaves to more complex condensed polyphenols known as theaflavins (dimers) and thearubigins (polymers). Catechin and epicatechin are the main flavonols in fruit, whereas gallocatechin, epigallocatechin, and epigallocatechin gallate are found in certain seeds of leguminous plants, in grapes, and more importantly in tea.

\subsection{Flavanones}

This class of flavonoids can occur as O-or C-glycosides and is abundant in citrus fruit and prunes [21]. The hydrolysis of glycoside flavanones produces the not sugar component named aglycones, of which the most common are naringenin in grapefruit, hesperetin in oranges, and eriodictyol in lemons. Flavanones are generally glycosylated by a disaccharide at position seven: either a neohesperidose, which imparts a bitter taste (such as to naringin in grapefruit), or a rutinose, which is flavourless. 


\subsection{Anthocyanins}

Anthocyanins represent one of the pigment groups responsible for colour in some fruits and flowers [22-24]. They derive from the link of anthocyanidins in one or more glycosidic units, which may be linked to the anthocyanidin by $\alpha$ or $\beta$ linkage, and always in position 3 of the aglycon. When additional sugars are present in the anthocyanin molecule, they are linked to positions 5 and 7 , and less frequently to $3^{\prime}$ and $5^{\prime}$. The sugars encountered in anthocyanins can be hexoses (glucose and galactose) and pentoses (xylose, arabinose) [25]. Anthocyanin molecules are unstable and easily degraded [26] by temperature, $\mathrm{pH}$, light, oxygen, solvents, metallic ions, ascorbic acid, sulphites, and enzymes $[22,27]$.

\subsection{Isoflavones}

Isoflavones (family of phytoestrogens) are a group of oxygen heterocycle compounds [28]. The most common isoflavones are daidzein, genistein, and glycitein [29] which occur in legumes, especially in soybean [30]. The main forms of isoflavones in plants are glycosides with sugar such as glucose, malonylglucose, acetylglucose, galactose, and rhamnose.

\subsection{Phenolic Acids}

These compounds consist of a benzene ring bonded to a carboxylic group or a propenoic acid, generating benzoic acids and cinnamic acids respectively. Hydroxybenzoic acids are components of complex structures such as hydrolysable tannins (e.g., gallotannins and ellagitannins). The hydroxycinnamic acids, rarely found in the free form, are more common than hydroxybenzoic acids and consist mainly of p-coumaric, caffeic, ferulic, and sinapic acids [31]. This group of acids is found in all parts of fruit, although the highest concentrations are seen in the outer parts of ripe fruit. Caffeic acid is generally the most abundant phenolic acid and represents between $75 \%$ and $100 \%$ of the total hydroxycinnamic acid content of most fruit.

\subsection{Lignans}

These phenolic compounds are formed of two phenylpropane units. Lignans are metabolized to enterodiol and enterolactone by the intestinal microflora. The richest dietary source is linseed, which contains secoisolariciresinol and low quantities of matairesinol [32].

\subsection{Stilbenes}

These compounds display two aromatic rings linked by an ethane bridge, and exist in monomeric (resveratrol, oxyresveratrol) and oligomeric form as oligomers of stilbenes (dimmers, trimers, or polymers of resveratrol) or other stilbenes (e.g., epsilon-viniferin, pallidol, etc., [33]). Resveratrol, an important stilbene with anticarcinogenic properties, is found in low quantities in wine and occurs in two isomeric forms, the trans- and cis-isomers.

\subsection{Tannins}

According to their structure, tannins can be broadly divided into two classes of macromolecules, termed hydrolysable tannins and condensed tannins. Hydrolysable tannins contain a central core of polyhydric alcohol such as glucose, and hydroxyl groups, which are esterified either partially or wholly by gallic acid (gallotannins) or hexahydroxydiphenic acid (ellagitannins [34]). In addition to their astringent character, they have important antioxidant activity [31]. The hydrolysable tannins occur in seed pods, bark and wood, fruits, and leaves or galls of plants belonging to the family Leguminosae, Fabaceae, Combretaceae, and Anacardiaceae. Condensed tannins or proanthocyanidins are high-molecular-weight polymers with a molecular mass of up to $30,000 \mathrm{Da}$. The monomeric form is a flavan-3-ol (catechin, epicatechin), with a flavan-3, 4-diol, or a leucoanthocyanidin molecule as its precursor. Condensed tannins are widely distributed in fruits, vegetables, forage, plants, cocoa, red wine, and certain food grains, such as sorghum, finger millets, and legume [34]. 
Table 1 presents polyphenol classes, examples of compounds containing polyphenols, and their presence in plant sources. Figure 2 shows the biological properties of polyphenols found in human, animal models, and livestock, and the main specific effects found in final products are presented in Table 2 .

Table 1. Polyphenolic classes, compounds and plant sources.

\begin{tabular}{|c|c|c|c|}
\hline Group & Class & Compounds & Plant Sources \\
\hline \multirow{6}{*}{$\begin{array}{l}\text { Flavonoid- } \\
\text { polyphenols }\end{array}$} & Flavonols & $\begin{array}{l}\text { Quercetin, kaempferol, } \\
\text { isorhamnetin }\end{array}$ & $\begin{array}{c}\text { Vitis vinifera grape berry skins, onions, leeks, } \\
\text { broccoli, black tea, lettuce, apples, green tea, } \\
\text { wine, dill weed }\end{array}$ \\
\hline & Flavones & Apigenin, luteolin, diosmin & $\begin{array}{l}\text { Celery, red pepper, lemon, onion, oregano, } \\
\text { rosemary, parsley, trollflowers }\end{array}$ \\
\hline & Flavanols & $\begin{array}{l}\text { Catechin, proanthocyanidins, } \\
\text { epicatechin, epigallocatechin }\end{array}$ & $\begin{array}{c}\text { Tea, grapes, red wine, apples, blackberries, } \\
\text { apricots, dark chocolate }\end{array}$ \\
\hline & Flavanones & $\begin{array}{l}\text { Naringenins, hesperetin, } \\
\text { eriodictyol }\end{array}$ & $\begin{array}{l}\text { Grapefruit, oranges, tangerines, peppermint, } \\
\text { lemons, limes, defatted olive }\end{array}$ \\
\hline & Anthocyanins & $\begin{array}{l}\text { Cyanidin, perlargonidin, } \\
\text { delphinidin }\end{array}$ & $\begin{array}{l}\text { Blackberries, cherries, strawberries, } \\
\text { raspberries, chokeberries, tomatoes, grapes, } \\
\text { green coffee beans, red cabbage, sweet potatoes }\end{array}$ \\
\hline & Isoflavones & Genistein, daidzein, equol & Peas, soybean, lentils, red kidney beans \\
\hline \multirow{3}{*}{$\begin{array}{l}\text { Non-flavonoid- } \\
\text { polyphenols }\end{array}$} & Phenolic acids & $\begin{array}{l}\text { Caffeic acid, chlorogenic acid, } \\
\text { ferulic acid }\end{array}$ & $\begin{array}{c}\text { Coffee, olive, cabbage, apples, cherries, } \\
\text { tomatoes, pears, green coffee beans, } \\
\text { dried ginger }\end{array}$ \\
\hline & Lignans & $\begin{array}{l}\text { Pinoresinol, podophyllotoxin, } \\
\text { stegananic, matairesinol }\end{array}$ & $\begin{array}{l}\text { Linseeds, sesame seeds, chives, nuts, roots, } \\
\text { leaves, vegetables, spices, cereals }\end{array}$ \\
\hline & Stilbenes & Resveratrol, pterostilbene & $\begin{array}{l}\text { Almond, chocolate, seeds, and skins of grapes, } \\
\text { red wine, peanuts, blueberries, raspberries }\end{array}$ \\
\hline Tannins & & $\begin{array}{l}\text { Tannic acid, Chinese tannin, } \\
\text { Turkish tannin, acer tannin, } \\
\text { ellagitannin, chebulagic acid }\end{array}$ & $\begin{array}{l}\text { Bean seed coats, persimmons, green coffee } \\
\text { beans, mango kernels, pomegranates, } \\
\text { strawberries, walnuts, almonds }\end{array}$ \\
\hline
\end{tabular}

\section{BIOLOGICAL PROPERTIES OF POLYPHENOLS}
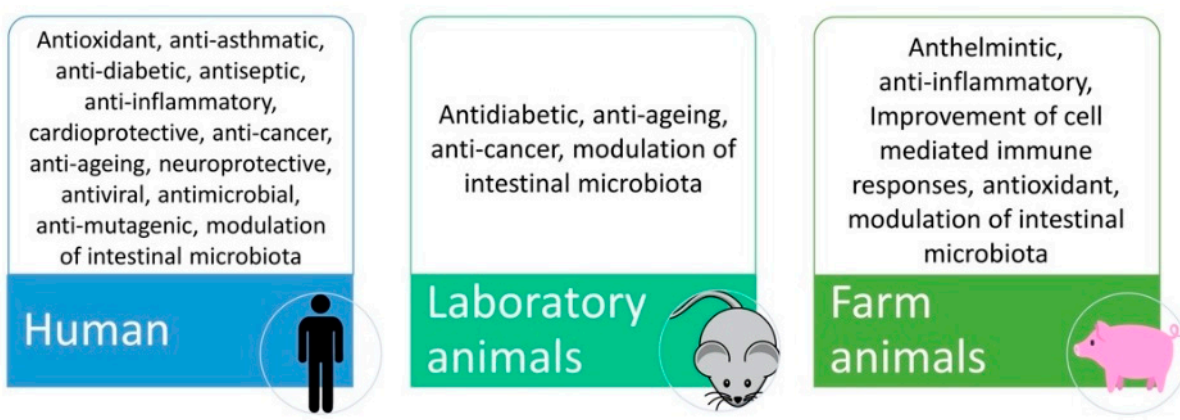

Figure 2. Biological properties of polyphenols exerted in human, animal models and farm animals.

\section{Bioavailability of Polyphenols in Food-Producing Animals}

Bioavailability can be defined as the proportion of bioactive compounds that are successfully absorbed into the bloodstream for metabolic utilization [35]. Polyphenols are considered as bioactive compounds, that unlike macro- and micronutrients, are not essential for life, but have an effect on specific cells and tissues. Their availability is determined by the type of compound, its chemical and physical properties, and the type and presence of functional groups $[8,36]$.

In the monogastric gastrointestinal tract, phenolic compounds metabolism starts from the upper intestinal epithelia and proceeds to the lower intestine, the liver, and then to the peripheral tissues, which include adipose tissue and the kidneys. The route of phenolic 
absorption can either be via the stomach and small intestine or possibly absorbed by the colon after chemical modification by the colonic microbiota. The microbiota present in the colon allows polyphenols to be absorbed into the bloodstream and subsequently to be excreted either in the urine or via the bile [37]. It has been shown that out of $100 \%$ total polyphenolic intake, only $5-10 \%$ is absorbed in the small intestine, while the $90-95 \%$ will be in the large intestine lumen together with other conjugates excreted by the bile $[37,38]$. Subsequently, they are exposed to the intestinal enzymes and gut microbiota, which breaks down the polyphenolic structures into smaller molecules to facilitate absorption. In the animal, polyphenols are transformed into glycoside, ester, and polymeric forms that need to be hydrolysed to facilitate absorption by gut microbiota and intestinal enzymes. Phenolic compounds with fewer complex structures are subjected to extensive biotransformation (oxidation, reduction, or hydrolysis) which converts them into water-soluble metabolites in the enterocytes before reaching the liver. The complex phenolic compounds not absorbed in the small intestine reach the colon, where the gut microbiota hydrolyses glycosides resulting in the formation of aglycones. This process decreases the complex structure of the phenolic hydroxyl group into low-molecular-weight phenolic metabolites that can be absorbed. Once absorbed, the molecules reach the liver via the hepatocytes, where they are again subjected to a biotransformation process (conjugation) which improves easy absorption (hydrophobicity) of the molecules and aids in rapid elimination. Finally, the metabolites enter the systemic circulation where they are distributed to the targeted organs or eliminated in the urine [39,40]. A schematic illustration of the described absorption and metabolism of plant polyphenols is summarized in Figure 3.

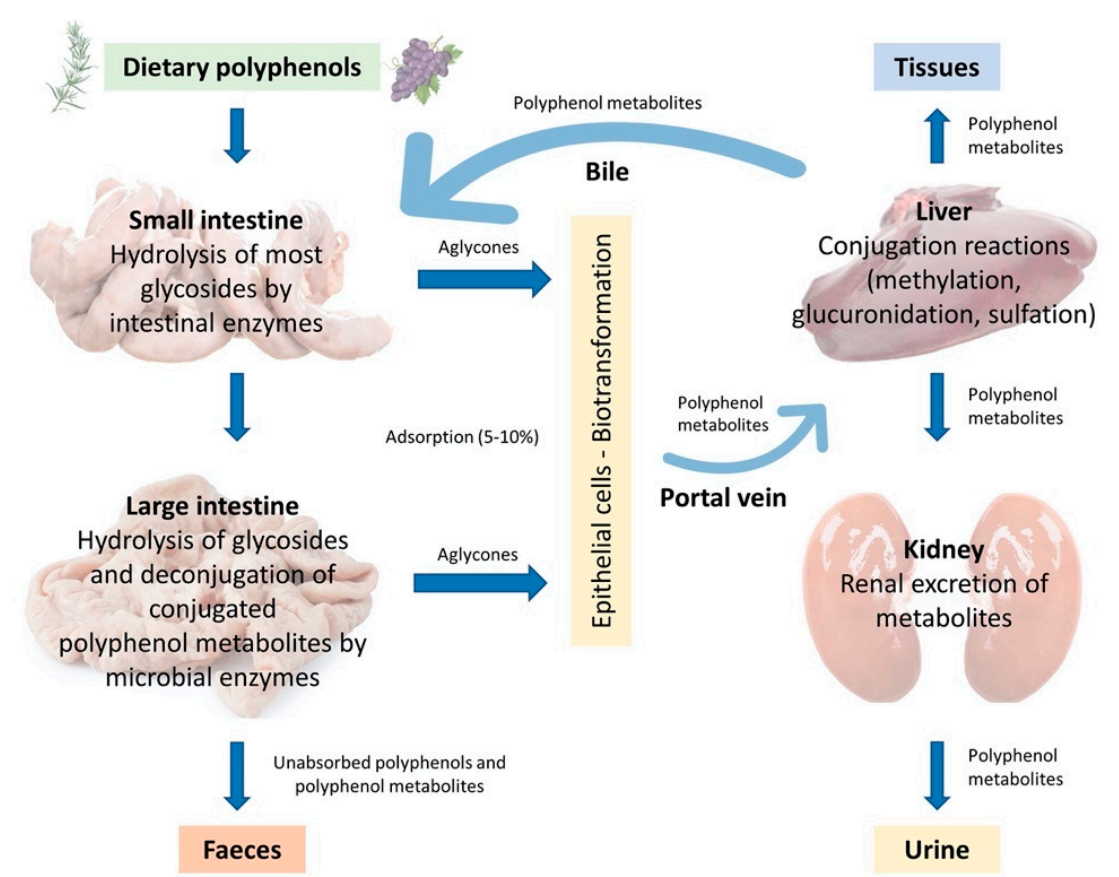

Figure 3. Adsorption and metabolism of plant polyphenols in monogastric farm animals (Adapted from Marín et al., 2014 [41]).

The content of polyphenols in body tissues is not directly related to their dietary levels $[36,42,43]$. For example, it has been shown that in pigs whose diets were supplemented with $50 \mathrm{mg} / \mathrm{kg}$ quercetin for 4 weeks, quercetin levels were higher in the kidneys $(6.31 \mathrm{nmol} / \mathrm{g})$ and colon $(13.92 \mathrm{nmol} / \mathrm{g})$ than in the liver $(2.83 \mathrm{nmol} / \mathrm{g})$ or plasma $(0.67 \mu \mathrm{mol} / \mathrm{L})$ [44]. On the contrary, when pig diets were supplemented with higher doses of quercetin $(500 \mathrm{mg} / \mathrm{kg}$ ) for 3 days, quercetin levels remained unchanged in bodily tissues $(3.78 \mathrm{nmol} / \mathrm{g}$ in the liver, $1.84 \mathrm{nmol} / \mathrm{g}$ in the kidneys), but increased in plasma $(1.1 \mu \mathrm{mol} / \mathrm{L})$ [45]. In these works, elevated polyphenol concentrations were noted only in 
organs that participate in the metabolism of the polyphenolic compound. The levels of unabsorbed dietary phenolic compounds exert significant effects on the intestinal environment by suppressing or stimulating the growth of some of the components of intestinal microbiota. The dietary polyphenols present prebiotic properties and exert antimicrobial activities, they enhance the growth of specific beneficial bacteria strains (Bacillus spp., Lactobacillus spp.) in the intestinal tract while competitively excluding certain pathogenic bacteria and stabilizing gut microbiota; indirectly enhance the host's immune system and overall health $[46,47]$. On intestinal morphology, they can exert a positive influence and improve nutrient absorption in monogastric animals [48].

Contrary to what is known about the monogastric, for which it has been clearly established that the small intestine is the main site of absorption for monomeric flavonoids, it is still unknown if flavonoids are absorbed across the rumen epithelium. However, several studies have shown an early peak in plasma flavonoid concentrations after intraruminal administration of quercetin [49] or consumption of a meal containing abundant isoflavones [50], thus suggesting that some flavonoids are adsorbed in the rumen, given that mean ruminal residence time of ingested feed is much greater than $1 \mathrm{~h} \mathrm{[51].} \mathrm{Conse-}$ quently, flavonoids that come out of the rumen are probably absorbed in the small intestine due to the increase in the total plasma concentration of flavonol after intraduodenal infusion of quercetin [52]. In dairy cows, it has moreover been shown that the administration of feedstuffs rich in isoflavones (genistein, daidzein) such as soybean meal or red glover silage causes an increase in the concentrations of those isoflavones in blood and milk [53,54]. The supplementation of phenolic compounds in ruminants seems to be effective in preserving polyunsaturated fatty acids (PUFA), rumenic acid, and vaccenic acid from a complete biohydrogenation, with consequent enriching in health-promoting fatty acids in meat and milk, at the expense of saturated fatty acids. The effects of phenolic compounds on cellulolytic bacteria and protozoa probably are also associated with the reduction of both fibre degradability and, indirectly, with methane emission. However, a direct interaction between some specific phenolic compounds (such as hydrolysable tannins) and methanogen microbes was suggested [55].

\section{Antioxidants and Their Importance in Food-Producing Animals}

The efficacy of animal production is based principally on balanced nutritional systems that meet the individual needs of farm animals. Animal growth can be influenced or even regulated by the supplementation of antioxidants in animal feed; thus, it is likely to be affected by the overall redox status of a productive animal [56].

It has been suggested that the high metabolic rate of growing tissues generates abnormally large amounts of free radicals. To avoid the formation of free radicals that usually lead to oxidative stress and other redox-related pathologies, they must be safely scavenged or removed via the administration of antioxidant compounds [57,58]. Oxidative stress is defined as "the imbalance between oxidants and antioxidants in favour of the oxidants, potentially leading to damage" [59]. A particularly destructive aspect of oxidative stress is the excessive production of reactive oxygen species (ROS), such as free radicals and peroxides, that cannot be effectively neutralized by the body $[60,61]$. In homeostasis, ROS are deactivated by endogenous antioxidants represented by enzymatic antioxidants (superoxide dismutase, catalase, and glutathione peroxidase) and non-enzymatic antioxidants (uric acid, glutathione, coenzyme Q; [61]). In recent years, evidence has emerged that oxidative stress plays a crucial role in the development and perpetuation of inflammation [62], and the potential of plant polyphenols to combat oxidative stress and inflammatory processes in farm animals is fully described by Gessner and colleagues [7]. In pigs, grape seed and grape marc meal extracts or hop extract $(10 \mathrm{~g} / \mathrm{kg}$ diet $)$, have shown to be able to lower the expression of several proinflammatory genes in various portions of the intestine (duodenum, ileum, colon; [63]). The abundance of some potentially pathogenic bacteria was lowered, thus suggesting that polyphenols exerted an antimicrobial effect on pathogenic bacteria in the intestine. The positive effect was reflected in an improvement of the gain- 
to-feed ratio in pigs, due to an inhibition of pro-inflammatory processes in the intestine and to antimicrobial effects. An improvement in growth performance may be related to the improvement of immune defence and suppression of excessive apoptosis among intestinal epithelial cells, as observed in piglets [64] and poultry [65]. Another action of antioxidants is represented by an improvement of food status and animal feed intake as some plant extracts enhance the flavour and palatability of feed, which improves feed intake and productive performance $[66,67]$. The increased stimulation of appetite results in higher feed consumption and weight gain. With regards to plant extracts rich in polyphenols, they have been shown to increase digestive secretion such as saliva and digestive enzymes, thus improving the adsorption and utilization of nutrients which increases, in turn, the growth of the animals [68]. Some phenolic compounds like genistein, daidzein, soybean isoflavone, and ferulic acid have been proposed to exert effects on animal metabolism, thus acting as growth promoters by modulating animal metabolism in favour of increasing muscle tissue $[69,70]$ or increasing the bioavailability of nutrients [64]. Studies conducted in ruminants have mainly been focused on inducing changes in the microbial populations of the rumen and its subsequent effects on ruminal fermentation. However, dietary supplementation with ferulic acid to steers has been shown to exert effects similar to $\beta$-adrenergic agonists that are used in the final phase of intensive fattening of beef cattle [71].

Moreover, in intensive breeding systems, animals are frequently exposed to oxidation of fatty acids (lipoperoxidation), not only because of their frequent exposure to oxidative stress but also because of their diet [72]. On this basis, numerous studies over the past few years have examined the hypothesis that the supplementation of feed that is enriched with antioxidants to farm animals will provide an improvement of derived product quality [73-77]. As regards meat quality, parameters, such as colour, water-holding capacity, and the oxidative stability of lipids and proteins are usually referred to [77]. Lipid oxidation is a major quality deteriorative process in muscle foods resulting in a variety of breakdown products that produce off-odours and flavours, drip losses, discoloration, loss of nutrient value, decrease in shelf life, and accumulation of toxic compounds [78]. The interaction of alkyl and peroxyl radicals, which are formed during the oxidation of lipids, leads to the formation of non-radical products such as aldehydes [79], directly related to the deterioration of meat colour and flavour, protein stability, and functionality [78].

Another phenomenon closely associated with deteriorative processes that can affect meat and meat products is the oxidation of proteins, which play a fundamental role in meat quality concerning the sensory, nutritional and physico-chemical properties [78]. Protein oxidation occurs through a chain reaction of free radicals like oxidation of lipids in animal muscle. This process induces multiple physico-chemical changes and nutritional value in meat proteins including a decrease in the bioavailability of amino acid protein, change in amino acid composition, decrease in protein solubility due to protein polymerization [80]. Oxidative damage in tissues should be prevented at an early stage by controlling animal diets $[37,80,81]$ and consequently, stabilizing the antioxidant potential of products of animal origin. There is a growing interest in the nutritional aspect of polyphenolic compounds in light of their antioxidant capacity and they may become an important alternative as a partial substitute for vitamin E in animal diets [37]. Polyphenols have a saving action on vitamin antioxidants such as ascorbic acid and tocopherols [82]. Polyphenols, minimizing the adverse consequences of lipid peroxidation by decreasing malondialdehyde concentrations and increasing tocopherol levels in tissues, improve the quality of animal products [4].

\section{Supplementation of Polyphenols to Animal's Diet}

The use of plant-rich polyphenols seems to be a promising strategy for improving animal product quality through animal diet, and several studies have proven their effects in foodproducing animals (Table 2). In fact, the number of publications indexed by Web of Science (https: / / www.webofknowledge.com (accessed on 23 December 2020)) on polyphenols and their use as feed additives has increased over the years, since 2000 (Figure 4). 
Table 2. Natural sources of antioxidants used as feed additives for monogastric and ruminants and main effects found in final products.

\begin{tabular}{|c|c|c|c|c|c|c|c|}
\hline $\begin{array}{l}\text { Animal } \\
\text { Species }\end{array}$ & Animal Product & Source & Dose Diet & $\begin{array}{l}\text { Concentration } \\
\text { Product }\end{array}$ & Storage Days & Effect & Reference \\
\hline Chicken & $\begin{array}{c}\text { Raw and cooked } \\
\text { breast meat patties }\end{array}$ & $\begin{array}{l}\text { Grape (Vitis vinifera) pomace } \\
\text { concentrate }\end{array}$ & $60 \mathrm{~g} / \mathrm{kg}$ & - & 20 & $\begin{array}{c}\text { Inhibitory effect on lipid oxidation; } \\
\text { increase in radical } \\
\text { scavenging capacity }\end{array}$ & [83] \\
\hline Chicken & $\begin{array}{l}\text { Breast and } \\
\text { thigh meats }\end{array}$ & Grape (V. vinifera) pomace & $30 \mathrm{~g} / \mathrm{kg}$ & - & 7 & $\begin{array}{l}\text { Inhibitory effect on lipid oxidation } \\
\text { (decreased MDA values) }\end{array}$ & {$[84]$} \\
\hline Chicken & Breast meat & $\begin{array}{l}\text { Grape }(V \text {. vinifera) pomace } \\
\text { concentrate }\end{array}$ & $60 \mathrm{~g} / \mathrm{kg}$ & - & 7 & $\begin{array}{l}\text { Inhibitory effect on lipid oxidation } \\
\text { (decreased MDA values); } \\
\text { improvement of antioxidant activity } \\
\text { (in diet, ileal content, and excreta) }\end{array}$ & [85] \\
\hline Chicken & Breast meat & Grape (V. vinifera) pomace & $10 \mathrm{~g} / \mathrm{kg}$ & - & 10 & $\begin{array}{c}\text { Inhibitory effect on lipid oxidation; } \\
\text { decrease of redness and } \\
\text { yellowness values }\end{array}$ & [86] \\
\hline Chicken & Thigh meat & Grape (V. vinifera) pomace & $100 \mathrm{~g} / \mathrm{kg}$ & - & 4 & $\begin{array}{l}\text { Inhibitory effect on lipid oxidation; } \\
\text { increase in the meat } \\
\text { PUFA concentration }\end{array}$ & [87] \\
\hline Chicken & Breast meat & $\begin{array}{l}\text { Rosemary (R. officinalis L.) } \\
\text { powder + vitamin E }\end{array}$ & $0.5 \mathrm{~g} / \mathrm{kg}$ & - & 14 & Increase in oxidative stability & [89] \\
\hline Chicken & Minced thigh meat & $\begin{array}{c}\text { Pomegranate (Punica } \\
\text { granatum L.) pomace extract } \\
\text { (PPE) and } \\
\text { pomegranate pomace (PP) }\end{array}$ & $\begin{array}{l}0.3 \mathrm{~g} / \mathrm{kg}(\mathrm{PPE}) \\
3 \mathrm{~g} / \mathrm{kg}(\mathrm{PP})\end{array}$ & $\begin{array}{l}45 \mathrm{mg} \text { GAE /g meat } \\
\text { (TPC; PPE), } \\
42 \mathrm{mg} \mathrm{GAE/g} \mathrm{meat} \\
\text { (TPC; PP) }\end{array}$ & 11 & $\begin{array}{c}\text { Inhibitory effect on lipid oxidation } \\
\text { (decreased TBARS values); increase } \\
\text { in radical scavenging capacity; } \\
\text { decrease of } n-6 / n-3 \text { ratio }\end{array}$ & [90] \\
\hline
\end{tabular}


Table 2. Cont.

\begin{tabular}{|c|c|c|c|c|c|c|c|}
\hline $\begin{array}{l}\text { Animal } \\
\text { Species }\end{array}$ & Animal Product & Source & Dose Diet & $\begin{array}{l}\text { Concentration } \\
\text { Product }\end{array}$ & Storage Days & Effect & Reference \\
\hline Chicken & $\begin{array}{l}\text { Breast muscle, } \\
\text { fat, liver }\end{array}$ & Tea polyphenols & $15 \mathrm{~g} / \mathrm{kg}$ & - & - & $\begin{array}{c}\text { Inhibitory effect on oxidative stress } \\
\text { induced by corticosterone; } \\
\text { reduction of abdominal fat } \\
\text { content, plasma } \\
\text { triglyceride concentration and } \\
\text { liver weight }\end{array}$ & [91] \\
\hline Laying hens & Eggs & $\begin{array}{c}\text { Grape }(V . \text { vinifera }) \text { pomace } \\
\text { flour }\end{array}$ & $30 \mathrm{~g} / \mathrm{kg}$ & - & 30 & $\begin{array}{l}\text { Increase of laid eggs percentage; } \\
\text { decrease of yolk and albumen pH; } \\
\text { reduction of egg lipid oxidation; } \\
\text { decrease in contents of caproic, } \\
\text { butyric and margaric fatty acids }\end{array}$ & [92] \\
\hline Laying hens & Eggs & $\begin{array}{l}\text { Dried orange pulp } \\
\quad \text { (Citrus sinensis) }\end{array}$ & $90 \mathrm{~g} / \mathrm{kg}$ & - & $\begin{array}{l}28 \text { (room } \\
\text { temperature) } \\
90\left(4^{\circ} \mathrm{C}\right)\end{array}$ & $\begin{array}{l}\text { Improvement of egg yolk oxidative } \\
\text { stability; reduction in feed intake; } \\
\text { negative influence on egg quality } \\
\text { (lighter eggs, lower } \\
\text { eggshell percentage, } \\
\text { thickness, and strength, less orange } \\
\text { yolk colour) }\end{array}$ & [93] \\
\hline Pig & $\begin{array}{l}\text { Longissimus muscle } \\
\text { muscle }\end{array}$ & $\begin{array}{l}\text { Fermented grape }(V \text {. vinifera }) \\
\text { pomace product }\end{array}$ & $30 \mathrm{~g} / \mathrm{kg}$ & - & - & $\begin{array}{c}\text { Decrease of } \text { SFA }^{3} \text { (palmitic, stearic, } \\
\text { and arachidic acids) and increase of } \\
\text { PUFA concentrations; inhibitory } \\
\text { effect on } \\
\text { lipid oxidation (decreased TBARS } \\
\text { values); higher redness and } \\
\text { yellowness values }\end{array}$ & [94] \\
\hline Pig & $\begin{array}{l}\text { Raw and cooked } \\
\text { Longissimus dorsi } \\
\text { steaks }\end{array}$ & $\begin{array}{c}\text { Grape (V. vinifera) seed } \\
\text { extract (GSE) and bearberry } \\
(\mathrm{BB})\end{array}$ & $\begin{array}{l}0.7 \mathrm{~g} / \mathrm{kg}(\mathrm{GSE}) \\
0.7 \mathrm{~g} / \mathrm{kg}(\mathrm{BB})\end{array}$ & - & $\begin{array}{l}16 \text { (raw meat) } \\
28 \text { (cooked } \\
\text { meat) }\end{array}$ & $\begin{array}{l}\text { No effect on oxidative stability and } \\
\text { quality of raw and cooked meat }\end{array}$ & [95] \\
\hline Pig & Loin meat mixture & $\begin{array}{l}\text { Green tea (Camellia sinensis) } \\
\text { by-products }\end{array}$ & $20 \mathrm{~g} / \mathrm{kg}$ & - & - & $\begin{array}{c}\text { Inhibitory effect on lipid oxidation } \\
\text { (decreased TBARS values) }\end{array}$ & [96] \\
\hline
\end{tabular}


Table 2. Cont.

\begin{tabular}{|c|c|c|c|c|c|c|c|}
\hline $\begin{array}{l}\text { Animal } \\
\text { Species }\end{array}$ & Animal Product & Source & Dose Diet & $\begin{array}{l}\text { Concentration } \\
\text { Product }\end{array}$ & Storage Days & Effect & Reference \\
\hline Pig & $\begin{array}{l}\text { Longissimus dorsi } \\
\text { muscle, lard }\end{array}$ & $\begin{array}{c}\text { Rosemary (R. officinalis L.) } \\
\text { extract }\end{array}$ & $1 \mathrm{~g} / \mathrm{kg}$ & - & 5 & $\begin{array}{c}\text { Increase in PUFA content; increase } \\
\text { of oxidative stability (decreased } \\
\text { TBARS values) }\end{array}$ & [97] \\
\hline Pig & $\begin{array}{l}\text { Longissimus } \\
\text { lumborum muscle }\end{array}$ & Rosemary (R. officinalis L.) & $1 \mathrm{~g} / \mathrm{kg}$ & - & 5 & $\begin{array}{l}\text { No influence on meat lipid content; } \\
\text { improvement in meat fatty acid } \\
\text { profile (increase in the content of } \\
\text { PUFA of the n- } 3 \text { and n- } 6 \text { series); no } \\
\text { influence on shelf-life duration }\end{array}$ & [98] \\
\hline Pig & $\begin{array}{l}\text { Longissimus lumborum } \\
\text { muscle, "capocollo" } \\
\text { (neck pork meat) }\end{array}$ & $\begin{array}{l}\text { Rosemary (R. officinalis L.) } \\
\text { aqueous leaf extract }(\mathrm{R}), \\
\text { oregano (Origanum vulgare) } \\
\text { aqueous leaf extract }(\mathrm{O})\end{array}$ & $\begin{array}{c}2 \mathrm{~g} / \mathrm{kg}(\mathrm{R}) \\
2 \mathrm{~g} / \mathrm{kg}(\mathrm{O}) \\
1+1 \mathrm{~g} / \mathrm{kg}(\mathrm{OR})\end{array}$ & $\begin{array}{l}\text { 2.8 GAE/g dry meat } \\
\text { (TPC; O) } \\
\text { 3.2 GAE/g dry meat } \\
\text { (TPC; R) } \\
\text { 4.1 GAE/g dry meat } \\
\text { (TPC; OR) }\end{array}$ & - & $\begin{array}{l}\text { Increase in antioxidant activity } \\
\text { (higher GSH-Px values (O } \\
\text { diet), greater } \\
\text { appreciation of meat obtained from } \\
\text { animals fed a diet supplemented } \\
\text { with rosemary }\end{array}$ & [99] \\
\hline Pig & $\begin{array}{l}\text { Loin, bacon, chops } \\
\text { patties }\end{array}$ & $\begin{array}{c}\text { Cranberry (Vaccinium } \\
\text { macrocarpon) juice powder }\end{array}$ & $150 \mathrm{~g} / \mathrm{kg}$ & - & - & $\begin{array}{l}\text { No influence in oxidative stability; } \\
\text { decrease of redness and colour } \\
\text { intensity values }\end{array}$ & [100] \\
\hline Pig & Longissimus dorsi & $\begin{array}{l}\text { Tea polyphenols (TP), Lucta } \\
\text { sweetener, flax oil (FO) }\end{array}$ & $0.4 \mathrm{~g} / \mathrm{kg} \operatorname{diet}(\mathrm{TP})$ & - & - & $\begin{array}{l}\text { Increase of T-SOD and GSH-Px } \\
\text { (prevention of possible oxidations in } \\
\text { the muscle) }\end{array}$ & [101] \\
\hline Rabbit & $\begin{array}{l}\text { Longissimus dorsi, } \\
\text { hind legs }\end{array}$ & $\begin{array}{c}\text { Rosemary (R. officinalis L.) } \\
\text { aqueous extract (R), oregano } \\
\text { (O. vulgare) aqueous extract } \\
(\mathrm{O})\end{array}$ & $\begin{array}{c}2 \mathrm{~g} / \mathrm{kg}(\mathrm{R}) \\
2 \mathrm{~g} / \mathrm{kg}(\mathrm{O}) \\
1+1 \mathrm{~g} / \mathrm{kg}(\mathrm{RO})\end{array}$ & - & - & $\begin{array}{l}\text { Improvement of oxidative stability } \\
\text { (lower TBARS content, lower } \\
\text { oxidation degree); improvement of } \\
\text { protein content }\end{array}$ & [102] \\
\hline Rabbit & $\begin{array}{l}\text { Meat from } \\
\text { Longissimus lumborum } \\
\text { muscle }\end{array}$ & $\begin{array}{l}\text { Olive (Olea europaea L.) } \\
\text { pomaces }\end{array}$ & $50 \mathrm{~g} / \mathrm{kg}$ & - & - & $\begin{array}{l}\text { Inhibitory effect of lipid oxidation; } \\
\text { increase in MUFA content and } \\
\text { decrease in PUFA content; no } \\
\text { influence on meat physical traits }\end{array}$ & [103] \\
\hline
\end{tabular}


Table 2. Cont.

\begin{tabular}{|c|c|c|c|c|c|c|c|}
\hline $\begin{array}{l}\text { Animal } \\
\text { Species }\end{array}$ & Animal Product & Source & Dose Diet & $\begin{array}{l}\text { Concentration } \\
\text { Product }\end{array}$ & Storage Days & Effect & Reference \\
\hline Rabbit & $\begin{array}{c}\text { Meat from } \\
\text { Longissimus dorsi } \\
\text { muscle }\end{array}$ & $\begin{array}{c}\text { Spirulina (Arthrospira } \\
\text { platensis; S), thyme (Thymus } \\
\text { vulgaris; T) }\end{array}$ & $\begin{array}{l}50 \mathrm{~g} / \mathrm{kg}(\mathrm{S}) \\
30 \mathrm{~g} / \mathrm{kg}(\mathrm{T})\end{array}$ & - & 9 & $\begin{array}{l}\text { Reduction of lipid oxidation }(\mathrm{T}) ; \\
\text { improvement of colour parameters } \\
\text { (T); improvement in } \alpha \text {-tocopherol } \\
\text { and n-3 fatty acids content }(\mathrm{T}) ; \\
\text { reduction of drip loss }(\mathrm{T})\end{array}$ & [104] \\
\hline Rabbit & $\begin{array}{l}\text { Meat from } \\
\text { Longissimus thoracis } \\
\text { and lumborum muscle }\end{array}$ & $\begin{array}{l}\text { Bilberry (Vaccinium myrtillus } \\
\text { L.) pomace }\end{array}$ & $150 \mathrm{~g} / \mathrm{kg}$ & - & 60 & $\begin{array}{c}\text { No influence on carcass } \\
\text { characteristics, proximate } \\
\text { composition, lipid oxidation and } \\
\text { consumer acceptance of rabbit meat; } \\
\text { improvement of fatty acids profile } \\
\text { (increase of total n-3 PUFA) }\end{array}$ & [105] \\
\hline Dairy cattle & Milk, caciotta cheese & $\begin{array}{l}\text { Dried grape }(V . \text { vinifera }) \\
\text { pomace }\end{array}$ & $100 \mathrm{~g} / \mathrm{kg} \mathrm{DM}$ & - & $\begin{array}{l}28 \text { (caciotta } \\
\text { cheese) }\end{array}$ & $\begin{array}{l}\text { No influence on milk composition, } \\
\text { increase in the concentration of } \\
\text { linoleic acid and trans-vaccenic acid } \\
\text { (milk and caciotta cheese); increase } \\
\text { in rumenic acid (caciotta cheese); } \\
\text { darker colouring, harder } \\
\text { consistency, less sweet taste } \\
\text { (caciotta cheese) }\end{array}$ & [106] \\
\hline Dairy cattle & Milk & $\begin{array}{c}\text { Grape }(V \text {. vinifera }) \text { residue } \\
\text { silage }\end{array}$ & $100 \mathrm{~g} / \mathrm{kg} \mathrm{DM}$ & $\begin{array}{c}12.3 \mathrm{mg} \mathrm{GAE} / \mathrm{L} \\
\text { (TPC) } \\
\text { 1.3 mg QE/L } \\
\text { (flavonoids) }\end{array}$ & - & $\begin{array}{l}\text { No influence on milk yield, fat, } \\
\text { lactose, crude protein; decrease of } \\
\text { urea nitrogen and total solids; } \\
\text { increase in PUFA concentration and } \\
\text { PUFA/SFA ratio; no influence on } \\
\text { the concentration of total } \\
\text { polyphenols and flavonoids }\end{array}$ & [107] \\
\hline
\end{tabular}


Table 2. Cont.

\begin{tabular}{|c|c|c|c|c|c|c|c|}
\hline $\begin{array}{l}\text { Animal } \\
\text { Species }\end{array}$ & Animal Product & Source & Dose Diet & $\begin{array}{l}\text { Concentration } \\
\text { Product }\end{array}$ & Storage Days & Effect & Reference \\
\hline Dairy cattle & Milk & $\begin{array}{l}\text { Pelleted citrus pulp (PCP), } \\
\text { soybean oil }\end{array}$ & $\begin{array}{c}30 \mathrm{~g} / \mathrm{kg} \text { of soybean } \\
\text { oil and } 90 \mathrm{~g} / \mathrm{kg} \text { PCP } \\
\text { (SOCP-9); } \\
30 \mathrm{~g} / \mathrm{kg} \text { of soybean } \\
\text { oil and } 180 \mathrm{~g} / \mathrm{kg} \text { PCP } \\
\text { (SOCP-18) }\end{array}$ & $\begin{array}{c}27.2 \mu \mathrm{g} \text { GAE } / \mathrm{mL} \\
(\mathrm{SOCP}-9 ; \mathrm{TPC}) \\
31.1 \mu \mathrm{g} \mathrm{GAE} / \mathrm{mL} \\
\text { (SOCP-18; TPC) } \\
0.8 \mu \mathrm{g} \mathrm{QE} / \mathrm{mL} \\
\text { (SOCP-9; flavonoids); } \\
0.8 \mu \mathrm{g} \mathrm{QE} / \mathrm{mL} \\
\text { (SOCP-18; } \\
\text { flavonoids) }\end{array}$ & - & $\begin{array}{l}\text { Increase in polyphenols and } \\
\text { flavonoids content and total } \\
\text { ferric reducing } \\
\text { antioxidant power; decrease in SFA } \\
\text { content; increase in MUFA content }\end{array}$ & [108] \\
\hline Dairy cattle & Milk & Ensiled Moringa oleifera & $271 \mathrm{~g} / \mathrm{kg} \mathrm{DM}$ & - & - & $\begin{array}{c}\text { Improvement of milk yield, increase } \\
\text { in milk antioxidant capacity, } \\
\text { decrease in somatic cell } \\
\text { count content }\end{array}$ & [109] \\
\hline Dairy cattle & Milk & $\begin{array}{c}\text { Propolis (Baccharis } \\
\text { dracunculifolia) based } \\
\text { product (PBP), flaxseed oil }\end{array}$ & $1.2 \mathrm{~g} / \mathrm{kg} \mathrm{DM}$ & $\begin{array}{l}13.35 \mathrm{mg} \text { GAE } / \mathrm{L} \\
(\mathrm{TPC} ; \mathrm{PBP})\end{array}$ & - & $\begin{array}{c}\text { Increase of fatty acids trans9-18:1, } \\
\text { cis9, trans11-18:2 concentrations, } \\
\text { and total CLA content; increase of } \\
\text { total polyphenols concentration; } \\
\text { increase of reducing } \\
\text { antioxidant power }\end{array}$ & [110] \\
\hline Beef cattle & $\begin{array}{c}\text { Meat from } \\
\text { Longissimus thoracis } \\
\text { (LT) and } \\
\text { semitendinosus (ST) } \\
\text { steaks }\end{array}$ & $\begin{array}{l}\text { Plant extracts rich in } \\
\text { polyphenols (PERP) + } \\
\text { vitamin E }\end{array}$ & $7 \mathrm{~g} / \mathrm{kg}$ & - & 12 & $\begin{array}{l}\text { Protective effect against lipid } \\
\text { oxidation (lower MDA values; after } \\
12 \text { days aging under-vacuum) }\end{array}$ & [80] \\
\hline Beef cattle & $\begin{array}{l}\text { M. longissimus dorsi } \\
\text { (LD) steaks, cooked } \\
\text { LD slices }\end{array}$ & $\begin{array}{l}\text { Tea catechins (TC), rosemary } \\
\text { (R. officinalis L.) extracts (RE) }\end{array}$ & $\begin{array}{l}1 \mathrm{~g} \text { /animal/day (TC) } \\
1 \mathrm{~g} / \text { animal/day (RE) }\end{array}$ & - & 8 & $\begin{array}{l}\text { No significant influence on lipid } \\
\text { stability and surface redness (LD } \\
\text { steaks); no influence on sensory } \\
\text { properties and lipid stability } \\
\text { (cooked LD slices) }\end{array}$ & [111] \\
\hline
\end{tabular}


Table 2. Cont.

\begin{tabular}{|c|c|c|c|c|c|c|c|}
\hline $\begin{array}{l}\text { Animal } \\
\text { Species }\end{array}$ & Animal Product & Source & Dose Diet & $\begin{array}{l}\text { Concentration } \\
\text { Product }\end{array}$ & Storage Days & Effect & Reference \\
\hline Beef cattle & $\begin{array}{c}\text { Meat from M. } \\
\text { Longissimus lumborum }\end{array}$ & $\begin{array}{c}\text { Dried citrus pulp (DCP), } \\
\text { dried grape }(V . \text { vinifera }) \\
\text { pomace (DGP) }\end{array}$ & $150 \mathrm{~g} / \mathrm{kg} \mathrm{DM}$ & $\begin{array}{c}32.5 \mathrm{~g} \text { GAE/kg dry } \\
\text { matter (TPC; DCP) } \\
89.6 \mathrm{~g} \text { GAE/kg DM } \\
\text { (TPC; DGP) } \\
12.7 \mathrm{~g} \text { GAE/kg DM } \\
\text { (total tannins; DCP) } \\
50.7 \mathrm{~g} \mathrm{GAE} / \mathrm{kg} \mathrm{DM} \\
\text { (total tannins; DGP) }\end{array}$ & 9 & $\begin{array}{l}\text { Improvement of antioxidant activity } \\
\text { (DGP > DCP); inhibitory effect on } \\
\text { lipid oxidation (DGP < DCP); higher } \\
\text { value of lightness in beef; } \\
\text { improvement of beef shelf life }\end{array}$ & [112] \\
\hline Beef cattle & $\begin{array}{l}\text { Longissimus dorsi } \\
\text { steaks }\end{array}$ & Olive cake & $5 \mathrm{~g} / \mathrm{kg} \mathrm{DM}$ & - & 9 & $\begin{array}{l}\text { Inhibitory effect of lipid oxidation; } \\
\text { delay of colour deterioration and } \\
\text { off-odour during storage; reduction } \\
\text { of peroxide value; no influence on } \\
\text { microbial counts }\end{array}$ & [113] \\
\hline Beef cattle & $\begin{array}{l}\text { Fresh and cooked } \\
\text { beef from Longissimus } \\
\text { thoracis muscle }\end{array}$ & Dried citrus pulp (DCP) & $800 \mathrm{~g} / \mathrm{kg} \mathrm{DM}$ & $\begin{array}{c}0.92 \mathrm{mg} \text { GAE } / \mathrm{g} \\
\text { muscle (TPC) }\end{array}$ & $\begin{array}{l}14 \text { (fresh beef) } \\
6 \text { (cooked } \\
\text { beef) }\end{array}$ & $\begin{array}{c}\text { No influence on TBARS } \\
\text { concentration (fresh beef); reduction } \\
\text { of lipid oxidation ( } 40 \% \text { DCP in } \\
\text { cooked beef); no negative influence } \\
\text { on texture } \\
\text { characteristics and } \\
\text { consumer acceptability }\end{array}$ & [114] \\
\hline Goat & Milk, cheese & $\begin{array}{c}\text { Distilled thyme (T. zygis } \\
\text { subsp. gracilis) leaves (DTL), } \\
\text { not-distilled thyme leaves } \\
\text { (TL) }\end{array}$ & $\begin{array}{l}200 \mathrm{~g} / \mathrm{kg} \mathrm{DM} \text { (DTL) } \\
75 \mathrm{~g} / \mathrm{kg} \mathrm{DM}(\mathrm{TL})\end{array}$ & $\begin{array}{l}400 \mathrm{mg} \text { GAE } / \mathrm{kg} \text { of } \\
\text { cheese (TPC; DTL) } \\
450 \mathrm{mg} \text { GAE } / \mathrm{kg} \text { of } \\
\text { cheese (TPC; TL) }\end{array}$ & 45 (cheese) & $\begin{array}{l}\text { Improvement of milk quality } \\
\text { (increase in PUFA content); } \\
\text { inhibitory effect on lipid oxidation } \\
\text { (TBARS values } \\
\text { decreased; TL); improvement of } \\
\text { sensory characteristics (DTL: best } \\
\text { rind and taste) }\end{array}$ & [115] \\
\hline Goat & Milk & Acacia farnesiana pods & $300 \mathrm{~g} / \mathrm{kg} \mathrm{DM}$ & $\begin{array}{l}305.5 \mathrm{mg} \text { GAE/L of } \\
\text { milk (TPC) }\end{array}$ & - & $\begin{array}{l}\text { Improvement of antioxidant activity } \\
\text { (scavenging capacity increased, } \\
\text { higher Trolox equivalent value, } \\
\text { higher ferric reducing antioxidant } \\
\text { power value) }\end{array}$ & [116] \\
\hline
\end{tabular}


Table 2. Cont.

\begin{tabular}{|c|c|c|c|c|c|c|c|}
\hline $\begin{array}{l}\text { Animal } \\
\text { Species }\end{array}$ & Animal Product & Source & Dose Diet & $\begin{array}{l}\text { Concentration } \\
\text { Product }\end{array}$ & Storage Days & Effect & Reference \\
\hline Goat & $\begin{array}{c}\text { Meat from M. } \\
\text { longissimus dorsi (LD), } \\
\text { gluteus medius (GM) } \\
\text { and } \\
\text { semimemberanosus } \\
(\mathrm{SM}) \text { muscles }\end{array}$ & $\begin{array}{c}\text { Tea catechins (TC) from } \\
\text { green tea }(C \text {. sinensis) leaves }\end{array}$ & $4 \mathrm{~g} / \mathrm{kg}$ & - & - & $\begin{array}{l}\text { Improvement of antioxidant activity } \\
\text { (TBARS values decreased), } \\
\text { improvement of meat colour } \\
\text { stability; decrease of drip loss } \\
\text { percentage (GM); decrease of } \\
\text { intramuscular fat (SM) }\end{array}$ & [117] \\
\hline Goat & $\begin{array}{l}\text { Meat from M. } \\
\text { longissimus thoracis } \\
\text { and lumborum muscle }\end{array}$ & M. oleifera leaves & $200 \mathrm{~g} /$ animal/day & $\begin{array}{l}1.62 \pm 0.27 \mathrm{mg} \mathrm{GAE} \\
\quad / \mathrm{g} \text { of meat }(\mathrm{T})\end{array}$ & - & $\begin{array}{l}\text { Improvement of antioxidant activity; } \\
\text { increase in scavenging potential; } \\
\text { increase of percentage of inhibition } \\
\text { against lipid oxidation; increase in } \\
\text { SOD activity }\end{array}$ & [118] \\
\hline Goat & $\begin{array}{l}\text { Meat from Muscularis } \\
\text { longissimus thoracis } \\
\text { and lumborum muscle }\end{array}$ & $\begin{array}{l}\text { Olive mill wastewaters } \\
(\text { OMWW) powder extract }\end{array}$ & $0.0032 \mathrm{~g} /$ day & - & 7 & $\begin{array}{l}\text { Increase in MUFA concentration, } \\
\text { decrease in SFA concentration; } \\
\text { inhibitory effect of lipid oxidation } \\
\text { (reduction of MDA content); } \\
\text { no significant influence on meat } \\
\text { proximate composition; texture and } \\
\text { colourimetric properties }\end{array}$ & [119] \\
\hline Sheep & Pecorino cheese & $\begin{array}{c}\text { Rosemary (R. officinalis L.) } \\
\text { leaves }\end{array}$ & $2.5 \%$ & $\begin{array}{l}2.14 \mathrm{mg} \text { GAE / g of } \\
\text { cheese (TPC after } \\
3 \text { weeks from the } \\
\text { start of the trial) } \\
2.62 \mathrm{mg} \text { GAE/g of } \\
\text { cheese (TPC after } \\
5 \text { weeks from the } \\
\text { start of the trial) } \\
3.60 \mathrm{mg} \text { GAE/g of } \\
\text { cheese (TPC after } \\
7 \text { weeks from the } \\
\text { start of the trial) }\end{array}$ & - & $\begin{array}{l}\text { Increase in the total polyphenol } \\
\text { concentration in milk and Pecorino } \\
\text { cheese; increase in antioxidant } \\
\text { activity of cheese; inhibitory effect } \\
\text { on lipid oxidation; no influence on } \\
\text { cheese composition; modification of } \\
\text { overall cheese flavour (after } 7 \text { weeks } \\
\text { from the start of the trial) }\end{array}$ & [120] \\
\hline
\end{tabular}


Table 2. Cont.

\begin{tabular}{|c|c|c|c|c|c|c|c|}
\hline $\begin{array}{l}\text { Animal } \\
\text { Species }\end{array}$ & Animal Product & Source & Dose Diet & $\begin{array}{l}\text { Concentration } \\
\text { Product }\end{array}$ & Storage Days & Effect & Reference \\
\hline Sheep & Milk, Pecorino cheese & $\begin{array}{l}\text { Fresh lemon (Citrus limon) } \\
\text { pulp }\end{array}$ & 2000 g/day & $\begin{array}{l}10.4 \mathrm{~g} \mathrm{GAE} / \mathrm{kg} \text { DM } \\
\text { (TPC) }\end{array}$ & - & $\begin{array}{l}\text { Influence on milk fatty acid } \\
\text { composition (improvement of } \\
\text { vaccenic and } \\
\text { rumenic acids); increase in milk } \\
\text { protein and casein percentages; } \\
\text { increase in } \\
\text { antioxidant activity of cheese and } \\
\text { total content of phenolic compounds }\end{array}$ & [121] \\
\hline Sheep & $\begin{array}{l}\text { Raw and cooked } \\
\text { minced lamb meat }\end{array}$ & $\begin{array}{c}\text { Rosemary (R. officinalis L.) } \\
\text { extract }\end{array}$ & $0.6 \mathrm{~g} / \mathrm{kg}$ & - & 21 & $\begin{array}{c}\text { Extension of raw meat shelf life } \\
\text { (lipid oxidation and rancidity } \\
\text { delayed), } \\
\text { no influence on the shelf life } \\
\text { duration of cooked meat }\end{array}$ & [122] \\
\hline Sheep & $\begin{array}{l}\text { Meat fillets from } \\
\text { Longissimus dorsi } \\
\text { muscle }\end{array}$ & $\begin{array}{c}\text { Rosemary (R. officinalis L.) } \\
\text { extract }\end{array}$ & $0.006 \mathrm{~g} / \mathrm{kg}$ & - & 21 & $\begin{array}{l}\text { Inhibitory effect on meat lipid } \\
\text { oxidation (MDA levels reduced) } \\
\text { and rancidity, prevention of sensory } \\
\text { deterioration }\end{array}$ & [123] \\
\hline Sheep & Milk & $\begin{array}{l}\text { Concentrated Pomegranate } \\
(P . \text { granatum L.) peel extract }\end{array}$ & $451 \mathrm{~g} / \mathrm{DM} / \mathrm{kg}$ & - & - & $\begin{array}{l}\text { Increase in milk antioxidant } \\
\text { capacity, improvement of milk yield } \\
\text { and } \\
\text { composition (higher phospholipid, } \\
\text { fat, protein and lactose content) }\end{array}$ & [124] \\
\hline
\end{tabular}

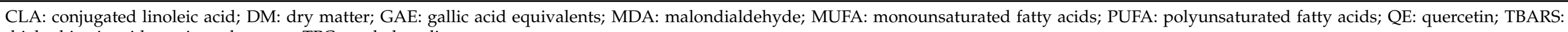
thiobarbituric acid reactive substances; TPC: total phenolic content. 


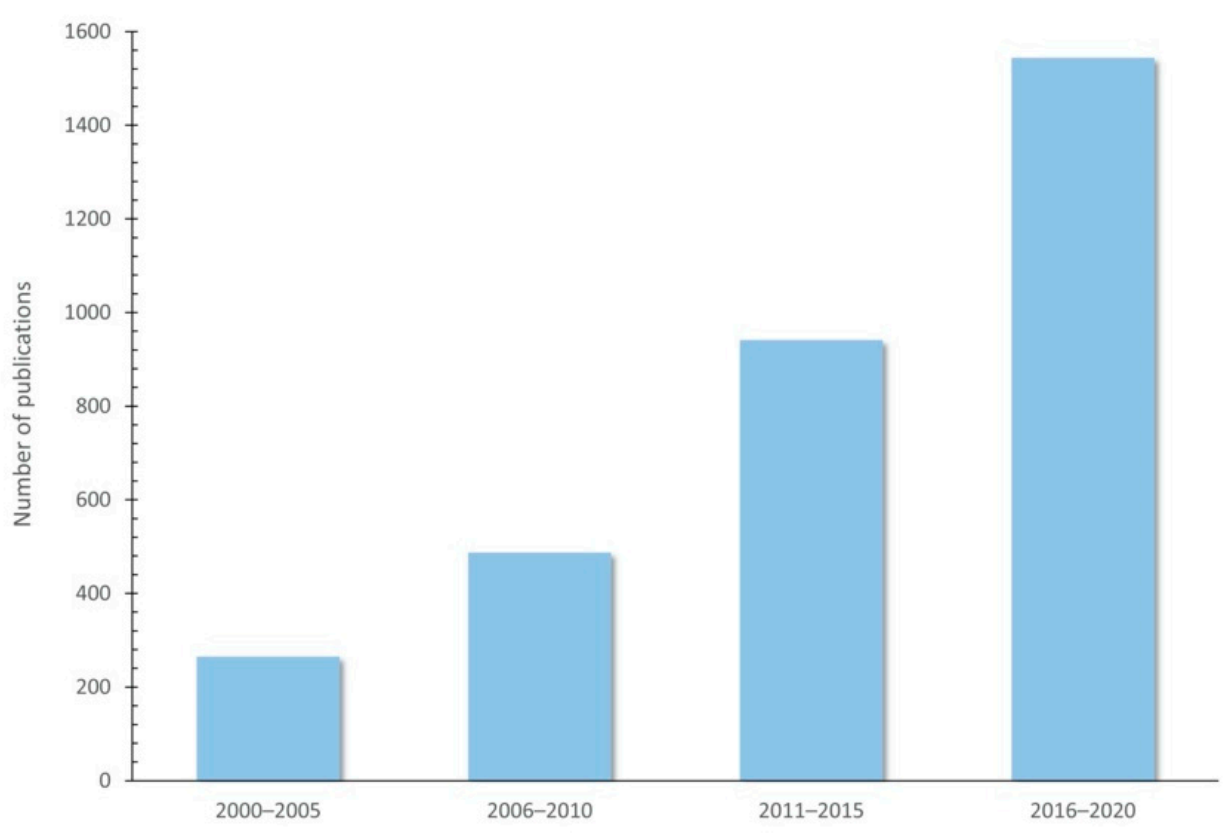

Figure 4. Increasing publications on polyphenols and their use as feed additives since 2000 (Indexed by Web of Science).

The optimum dose of inclusion of polyphenols in animal diets is difficult to define due to the different composition of phenolic compounds present in these products. Due to economic considerations, relevant sources of polyphenols for farm animals are agroindustrial by-products from juice, wine and beer making, such as pomace, peels, seeds, stems and brewery waste, and from the processing of grains, seeds and nuts, such as hulls (rice, buckwheat, almond) and husks (coconut). Polyphenols are present in virtually all matrices of plant origin, but some fruits, more than others, are particularly rich in these bioactive compounds, as in the case of grape. Grape (Vitis spp.) represents one of the most consumed and appreciated fruits in the world. Grape pomace, which mainly consists of grape seeds and skins, is the solid by-product of wine-making, approximately representing $20 \%$ of the total processed grapes, and has been reported to be a rich source of biologically active compounds, especially polyphenols. Several studies have reported that inclusion of grape by-products in animal diets not only retards oxidation but also improves meat quality when compared to diets with no antioxidants $[84,85,94,125,126]$. In the last two decades, the use of grape by-products as a dietary supplement for farm animals has been the focus of numerous experimentations. Other natural sources of polyphenols are represented by herbs of the Verbenacee, Lamiaceae family, especially rosemary, sage, oregano and green tea for which a particular emphasis has been given in the nutrition of farm animals. All of these herbs have been reported to possess antioxidant activity.

In the next paragraphs some findings of supplementation of polyphenols to the diet of monogastric and ruminants especially focused on quality parameters of final products, are presented. In fact, it has been demonstrated that dietary polyphenols do not undergo substantial metabolic modifications, thus enriching meat $[90,99,112,114,118]$ and dairy products $[107,108,110,115,116,120,121]$ with bioactive molecules originated from the diet.

\subsection{Monogastric}

Several studies report the inclusion of grape by-products in poultry and pigs' diets. Grape represents one of the major sources of phenolic compounds [127]. In this plant, the compounds found in the greatest proportion are the flavanols, which include simple monomers of catechin and its isomer epicatechin, as well as oligomeric proanthocyanidins and polymers commonly known as condensed tannins [128]. Extracts obtained from grape seeds and pomace are complex in composition and contain monomeric phenolic 
compounds such as $(+)$-catechins, $(-)$ epicatechin and $(-)$ epicatechin-3-O-gallate, and dimeric, trimeric, and tetrameric proanthocyanidins [129]. It is obvious that the biological activity of these polyphenols depends on their bioavailability. Moreover, not all active compounds have the same availability. For instance, the bioavailability of proanthocyanidins is highly reliant on the extent of polymerization [130], and association with other plant cell constituents like fibre and protein [7]. It has been demonstrated that skin proanthocyanidins have a higher grade of polymerization than proanthocyanidins extracted from seeds [131]. The use of grape by-products as antioxidants in animal feeds has been investigated by various authors not always with consistent results. In broiler chickens, different levels of grape pomace, 30 and $60 \mathrm{~g} / \mathrm{kg}$ feed from 3 to 6 weeks age [83], or $5 \mathrm{~g} / \mathrm{kg}, 7 \mathrm{~g} / \mathrm{kg}$ and $10 \mathrm{~g} / \mathrm{kg}$ for 28 days [86] have been shown to control and decrease thiobarbituric acid reactive substances (TBARS) level by their ability to scavenge free radicals. Although poultry meat contains a low lipid content, its relative concentration of polyunsaturated fatty acids ( $60 \%$ of total fat content) makes it particularly susceptible to oxidative deterioration and the integration results useful. It has been shown that the supplementation of polyphenols improves the antioxidative status and ameliorates oxidative stress in pigs, especially when they are subjected to prooxidative treatment. In fact, it has been reported that the inclusion of $1 \%$ of gallic acid, from grapes, wine and tea, with linoleic acid of diets administered for 36 days, improved the nutritional value (higher concentrations of arachidonic acid and docosahexaenoic acid) and water-holding capacity of breast broiler meat [81]. In this paper, the positive results of the treated samples are due to a significantly higher polyphenol content than that of control. Authors reported that gallic acid may directly combine with free radicals and lead to inactivate them which in turn decrease the intracellular concentration of free radicals. The addition of $5 \%$ dried grape pomace, a rich source of PUFA, in the diet for finishing pigs, improved the concentration of total n-3 PUFA especially alpha-linolenic fatty acids in Longissimus dorsi (LD) muscle after 12 days at $4{ }^{\circ} \mathrm{C}$ [132]. Similarly, PUFA content showed an increase in the meat of chicks fed the same grape-product $(0,5$, and $10 \%)$ [87]. Moreover, it has been reported that polyphenols, due to their 1-electron reduction potentials, may spare vitamin E to delay lipid oxidation and to regenerate tocopherol. In chickens, the dietary supplementation of grape pomace at $8 \%$ and grape seed extract at $0.1 \%$ determined a significantly higher plasma $\alpha$ - and $\gamma$-tocopherol concentration than the control group [133]. Similarly, an increase of $\alpha$-tocopherol concentration has been observed in the plasma of broiler chickens fed grape pomace at the level of 5 and 10\% [134] and in the liver of broilers fed $0.5,1.5$ and $3 \%$ [84]. The capacity of grape polyphenols to increase the concentration of vitamin $\mathrm{E}$ has also been observed in breast meat of broilers fed a diet supplemented with 100 and $200 \mathrm{mg} / \mathrm{kg}$ of a commercial product containing polyphenols derived from grape seeds [135]. This effect results in a better oxidative stability [84]. The administration of feed supplemented with grape pomace to weaned piglets increased significantly n-3 fatty acids such as eicosapentaenoic acid (EPA), docosahexaenoic acid (DHA) and alpha-linolenic acid (ALA) and decreased significantly n-6/n-3 ratio compared with control [136]. The supplementation of grape pomace in laying hens at $2 \%$ significantly decreased the egg yolk malondialdehyde (MDA) concentrations in fresh eggs at 0, 30 and 60-min incubations [137]. Moreover, a significantly higher egg weight $(p<0.001)$ has been observed in laying hens fed a diet containing $4 \%$ grape pomace compared to the control group, together with a reduction in yolk MDA concentration of either eggs analysed on the first day of collection or eggs stored at $+4{ }^{\circ} \mathrm{C}$ for 15 days [138]. Grape seeds are considered a relevant source of polyphenol compounds, mainly the monomerics catechin, epicatechin and gallic acid, and the polymeric and oligomeric procyanidins [139]. No influence on antioxidative parameters has been found in pigs receiving a diet supplemented with grape seed extract and bearberry at different levels (100, 300 and $700 \mathrm{mg} / \mathrm{kg}$ diet for both extracts; [95]). The supplementation of $5 \%$ grape seed to Penedes chickens did not show influences in protein, lipid and ash percentages of meat, but determined a higher percentage of unsaturated fatty acids due to linoleic acid. Concerning sensory analyses of cooked meat from the biceps 
femoris muscle, the inclusion of grape seed affects some parameters, giving a nuttier smell, more metallic flavour, more stringiness, less pork crackling odour, less pork crackling flavour, less sweet flavour and less broiler meat flavour [140]. These not positive effects found could be due to condensed tannins that can form complexes with proteins which are generally indigestible. Therefore, condensed tannins may have complexed with the protein present in the pelleted pig feed and hence become unavailable for absorption. The supplementation of different levels of grape seed $(0.5,1,1.5 \%)$ and grape seed extract $(675$, $1350,2025 \mathrm{mg} / \mathrm{kg}$ ) was used in laying hens increasing egg production linearly $(p<0.01)$, with the highest egg production value equal to $96.5 \%$ in the group receiving $675 \mathrm{mg} / \mathrm{kg}$ grape seed extract compared to the control group (77.1\%) [141]. Egg quality parameters were not affected by dietary treatments except for albumen index which increased linearly compared to control group, probably due by the protective effect exercised by grape seed on $\beta$-ovomucin, directly responsible for the quantity of albumen.

Another important source of polyphenols is represented by citrus by-products. The genus Citrus L. belongs to the family Rutaceae and is one of the most popular fruit crops in the world. It contains active phytochemicals that can protect the health, providing a wide supply of vitamin A, C, and E, folic acid, potassium and pectin. All these phytochemicals possess a wide variety of biological functions including antioxidant, anti-inflammatory, antimutagenic and anticarcinogenic properties [142,143]. In particular, citrus peel, which is most often discarded as waste, contains the highest amount of polymethoxylated flavones compared to other edible parts of the fruit [144]. A study evaluated the effects of including three different levels of ensiled citrus pulp (50, 100 and $150 \mathrm{~g} / \mathrm{kg}$ diet) in finishing pig diets on carcass quality and other parameters [145]. The results showed an increase of fat deposition at gluteus medius in pigs fed with 50 and $100 \mathrm{~g}$ of additive $/ \mathrm{kg}$, while the inclusion of $150 \mathrm{~g} / \mathrm{kg}$ has resulted in a reduction in both energy digestibility and fat deposition. However, the addition of ensiled citrus pulp slightly affects the fatty acid profile of the external sub-cutaneous fat layer, thus resulting benefits in terms of carcass quality. Another study reported that pigs fed citrus pulp (50 and $100 \mathrm{~g} / \mathrm{kg}$ ) had a lower fat thickness at the last rib [146]. Conversely, two works reported that dietary inclusion of $15 \%$ dried citrus pulp in diets of finishing pigs did not affect the backfat thickness and meat quality $[147,148]$. Nevertheless, it has been found that firmness of meat and meat colour were reduced, but juiciness was increased when dried citrus pulp was included at the levels of $22.5 \%$ or $30 \%$ [148]. In broiler chickens, the dietary supplementation of two different levels of citrus pulp (50 and $100 \mathrm{~g} / \mathrm{kg}$ ) modified the fatty acid composition of breast meat, improving n-3 and n-6 PUFA content, and reduced the breast skin redness, with no influence on meat total lipid content. Additionally, the inclusion of citrus pulp led to a considerable decrease in the levels of vitamin E homologues ( $\alpha$-Tocopherol, $\gamma$-Tocopherol, $\gamma$-Tocotrienol and $\delta$-Tocopherol; [149]).

Among polyphenols, verbascoside extracted from Lippia citriodora, showed antioxidant activity in pork meat and processed product. The effects on carcass characteristics, meat quality, oxidative stability and sensory attributes of L. dorsi of dietary supplementation with plant extract from Lippia spp., titrated in verbascoside ( $5 \mathrm{mg} / \mathrm{kg}$ feed), have been investigated in pigs from weaning to slaughter (166 days) [150]. Results showed lower $(p<0.001)$ lipid oxidation levels than controls. A reduction $(p<0.05)$ of fat odour and rancid flavour intensity in cooked LD muscle stored at $4{ }^{\circ} \mathrm{C}$ for $24 \mathrm{~h}$ was observed in the treated group. Even after a short period of dietary supplementation, the same extract was able to significantly $(p<0.05)$ limit the lipid oxidation in fresh muscle and reduce the TBARS concentration in processed pork product like Cremona salami with an improvement in colour that resulted more intensely in the treated group. These studies show that verbascoside is an effective antioxidant in pork meat, enhancing the oxidative status and sensory attributes, without affecting other meat quality parameters. This is in part related to the higher $\alpha$-tocopherol content in muscle of pigs fed polyphenols, confirming its sparing of Vitamin E. The protective effects of phenolic compounds in the prevention of lipid oxidation have been investigated in other studies. It has been observed that in sausage, 
apple polyphenols inhibited linoleic acid and cholesterol oxidation through their radical scavenging abilities [151]. Moreover, phenolic compounds inhibit free radical development and the propagation of free radical reactions through the chelation of transition metal ions, principally copper and iron [152].

Rosmarinus officinalis L. is an aromatic plant originating from the Mediterranean region belonging to the Lamiaceae family. Due to its antioxidant properties of leaves, rosemary has been widely accepted as one of the spices with the highest antioxidant activity, thus replacing or even decreasing synthetic antioxidants in foods [153]. Among the most effective antioxidant constituents of rosemary, the cyclic diterpene diphenols, carnosolic acid and carnosol have been identified. In addition, its extract contains carnosic acid, epirosmanol, rosmanol, methylcarnosate and isorosmanol [154,155]. This plant is a rich source of phenolic compounds and their properties are derived from its extracts [156] and essential oils [157]. The antioxidant properties are correlated to fruiting phases: during the fruiting stage, the increase in the concentration of polyphenols (carnosol, rosmarinic acid and hesperidin), is directly related to the improvement of the extract antioxidant capacity. Hesperidin, significantly influenced the $\mathrm{pH}$ and colour and lowered malondialdehyde concentrations in breast muscles of broilers after 3, 6 and 9 days of storage when added to diets in the amount of $3 \mathrm{~g} / \mathrm{kg}$ of feed [158].

\subsection{Ruminants}

As described above, the effectiveness in the prevention of adverse effects of the oxidative stress has been demonstrated through the supplementation of polyphenols or polyphenols and vitamin E added to compound feeding stuffs for monogastric, while, to the best of our knowledge, less investigated is dietary polyphenols supplementation and the quality of milk and dairy products. The major aim of polyphenols inclusion in ruminant nutrition, linked to the amelioration of food, is the reduction of biohydrogenation of PUFA, and the increase of the accumulation of vaccenic acid (VA) in rumen, increase the amount of these fatty acids reaching mammary gland and, consequently, the amount PUFA, VA and conjugated linoleic acid (CLA; derived from the enzymatic desaturation of VA) in milk. However, literature focusing on the alteration of ruminal biohydrogenation process and manipulation milk fatty acids profile is limited and results are not univocal [159]. Some works reported the ability of polyphenols to decrease SFA and increase the concentration of monounsaturated fatty acids (MUFA) and PUFA in milk [160]. Increased levels of $\omega-3$ FA, linoleic in particular, have been observed in milk from cows fed with a source of tannins [161]. The inclusion of pomegranate extract, as a source of secondary metabolites, in the diet of lactating dairy cows (4.56, 5.58 and $6.60 \mathrm{~g}$ of total phenols $/ \mathrm{kg}$ DM diet), was effective in improving milk fatty acid profile, by decreasing the concentration of SFA and the ration $\mathrm{n} 6 / \mathrm{n} 3$ and increasing the amount of EPA and DHA [162].

Anyway, grapes and its by-products have also been used in dairy cows' diets, for which an interesting perspective is a possibility of enriching milk with substances that have health benefits for its consumers. Dietary supplementation of $15 \%$ dried grape pomace to dairy cows in mid-lactation did not influence the milk yield and the milk protein and fat content, but increased the lactose and $\beta$-lactoglobulin concentration, giving the milk the properties of a functional food, particularly thanks to the biological activities of $\beta$ lactoglobulin, including antiviral action, pathogen adhesion prevention. In a study in which ten Friesian cows received for dietary supplementation of $10 \%$ grape pomace (on a dry matter basis) at 56 days, the milk collected at the end of the trial did not show variations in chemical composition [163]. This finding was also confirmed in pasteurized milk cheeses that were analysed after 3, 7, 15 and 30 days from the cheese-making. In that case, slight modifications were observed only for proteolysis and were associated with the action of proteinases and peptidases released by the cheese microbiota. During the cheese manufacturing, milk was pasteurized, with the only microbial forms being represented by Lactococcus spp., Lactobacillus spp. and S. thermophilus, which were used as starters. Such micro-organisms are reported to be responsible for extensive proteolytic activity 
in cheese, with the consequent production of short peptides and free amino acids. The authors discussed this finding by assuming the role of grape pomace bioactive compounds in favouring the metabolic pathways in lactic acid bacteria, leading to an increased function of proteolytic enzymes. The ability of a grape seed extract in increasing the growth of Lactobacillus at the expense of potentially harmful microbial forms, such as Enterobacteriaceae and Clostridium has been previously reported by another study [164].

It has been widely observed that the diet administered to lactating ruminants is commonly responsible for changes in the volatile profile of dairy products, both fresh and ripened $[165,166]$. It is, therefore, conceivable that compounds present in the diet, or secondary metabolites of the same, can be absorbed by the animal following digestion and then reach the mammary gland and be released into the milk [167]. Following cheese manufacturing, some of these compounds could influence the biochemical mechanisms described above, either directly interacting with the enzymatic forms responsible for these events, or indirectly through the regulation of bacterial gene expression.

Concerning the addition of polyphenols in small ruminant's diets, it has been observed a negative effect on milk production in Sarda dairy sheep after the dietary inclusion of $75 \mathrm{~g}$ of exhausted myrtle berries/day [168]. Depressive effects in the milk yield have been also reported in a study in which sheep were fed diet supplemented with olive leaves [169]. A general depressive effect in milk yield can be observed by increasing the concentration of polyphenols in the diet of sheep and goats, while a positive response in the milk yield is obtained when polyphenols are present at low concentrations [170]. Negative effects on milk composition have also been reported when a dairy sheep diet supplemented with $100 \mathrm{~g}$ tomato and grape by-products reduced the protein content caused by the lower rumen degradability of the tomato by-product [168]. Concerning the effects in other ruminants, the addition in lamb of $100 \mathrm{~g} / \mathrm{kg}$ dry matter of citrus and winery by-products improved the instrumental tenderness of meat by lowering shear force values [171,172]. The same inclusion level in lamb's diets increased slaughter, warm, and cold carcass weights and longissimus muscle area [132]. Concerning meat sensory attributes, the dietary supplementation of cinnamaldehyde and hesperidin, reported high off-flavour appreciation values in ovine meat [173]. On the contrary, the dietary inclusion of up to $80 \%$ dried citrus pulp in the diet of steers, did not negatively influence the texture characteristics and consumer acceptability of beef patties derived from these animals [114]. Goat kids fed with $3.2 \mathrm{mg} /$ day of polyphenols powder extract obtained from Olive mill wastewaters produced meat characterized by a significant reduction of short and saturated fatty acids. Furthermore, a higher $(p<0.05)$ proportion of monounsaturated fatty acids was recorded in the treated group with a concomitant lower $(p<0.05)$ MDA formation in the treatment group compared to control group, and no effects were recorded on PUFA [119]. As reported by authors the acidic composition of meat in ruminants is generally different from that of non-ruminants. The PUFA/SFA ratio is lower because of the hydrogenation of unsaturated fatty acid (UFA) in the rumen, while this process does not occur in monogastric that absorb UFA without any transformation in the gastrointestinal tract. Therefore, several UFA that are normally present in the diet of ruminants, are saturated and cannot be present in derived food. Thus, the diet plays the main role in the modification of fatty acid composition and rumen microbial population, as demonstrated by the evidence that rumen population activity on dietary UFA hydrogenation depends on the administered diet.

\section{Application of Phenolic Compounds in Food Products}

Plant extracts rich in polyphenols such as herbs and spices, have been used for many years to prevent lipid oxidation, retard development of off flavours and improve colour stability of food [174]. Their increase in the number of studies in food fortification has been mainly due to their antioxidant and free radical-scavenging properties and to their likely positive effects on human health. Moreover, due to their suspected carcinogenic potential, the use of the common synthetic antioxidants such as butylated hydroxytoluene (BHT) and butylated hydroxyanisole (BHA), is cause for concern [175]. Therefore, the use 
of natural antioxidants has the advantage of being more acceptable to the consumers as they consider these substances to be "non-toxic". The meat industry is actively looking for solutions increasing product shelf-life. For this purpose, technological strategies involve the application of these natural antioxidants, including the direct application of polyphenols into the meat and meat products or coating of packaging materials and results of several studies are reported (Table 3). Natural antioxidants, in addition to oxidation inhibition, may also affect other products quality attributes, influencing accordingly consumer acceptability (Table 3).

According to what previously described in animal dietary inclusion, grape by-products are commonly added directly in the final products resulting as an effective antioxidant in poultry, pork, beef and goat meat. The use of $60 \mathrm{mg}$ phenolic content $/ \mathrm{kg}$ meat of Niagara and Isabel (Vitis labrusca) grape seed and peel extracts was as effective as synthetic antioxidants $(0.01 \%$ BHT and $0.37 \%$ of sodium erythorbate-SE, citric acid, and sugar) at preventing lipid oxidation in raw and cooked chicken meat stored at $-18^{\circ} \mathrm{C}$ for 9 months [229]. In fact, the control treatment had significantly higher TBARS values $(p \leq 0.05)$ when compared to other treatments with antioxidants. There was no significant difference for oxidation inhibition between the synthetic antioxidants (BHT and SE) and the natural extracts, demonstrating the efficacy of the extracts as an antioxidant in chicken meat. The extract of both varieties did not alter the $\mathrm{pH}$ values of raw and cooked samples, confirming studies [230] in which grape seed extract was added to cooked and refrigerated ground chicken meat and cooked and refrigerated chicken breast [176]. Natural extracts used did not alter the colour of raw samples, but especially Isabel variety caused a lower intensity of red and yellow colour due to the dark colour of the extract. In the sensory evaluation, no significant alteration in odour and flavour score of the Isabel-treated samples has been observed; conversely, the variety Niagara interfered with the natural chicken meat flavour and odour, causing a wine/grape odour. Moreover, the grape seed extract reduced attributes associated with warmed-over flavour, such as the musty and rancid odours. The interference in both odour and flavour in the control due to the development of lipid oxidation and consequent development of uncharacteristic flavours has been effectively controlled in both raw and cooked chicken meat with the addition of grape seed extract.

Several studies have reported that antioxidant components in grape by-products can be changed or modified by different extraction procedures. Two different extraction systems (methanolic extraction Type I; methanolic extraction plus High-Low Instantaneous Pressure, Type II) have been used to obtain $0.06 \mathrm{~g} / 100 \mathrm{~g}$ grape pomace of final product concentration added in pork burgers packed under aerobic conditions $\left(4^{\circ} \mathrm{C}\right)$ at 0,3 , and 6 days post-storage [231]. The rapid expansion under the controlled condition that occurs in the type II treatment seems to negatively affect the concentration of the phenolic profile. Results in fact indicate the highest anthocyanins content in Type I extract pork burgers and the lowest TBARS during all times of storage. Concerning colourimetric parameters, more intense colour of the raw patties containing the Type I of grape extract has been observed, probably due to the highest content in total anthocyanins which act as potent natural colourants with a positive nutritional and therapeutic effect on human organism derived from its antiradical and antioxidant effect. No negative variation in the redness value has been observed in the burgers containing Type I grape extract, which could be due to the intense antioxidant activity of this compound; it is known that lipid oxidation and myoglobin deterioration are highly correlated, and the secondary products produced in lipid oxidation processes strongly promote colour deterioration. 
Table 3. Various sources used as natural antioxidants for meat and dairy products.

\begin{tabular}{|c|c|c|c|c|c|c|}
\hline Product & Source & Dose & Storage Conditions & $\begin{array}{l}\text { Concentration } \\
\text { Product }\end{array}$ & Effect & Reference \\
\hline $\begin{array}{l}\text { Cooked chicken } \\
\text { breast meat }\end{array}$ & $\begin{array}{l}\text { Grape (Vitis vinifera) seed, green } \\
\text { tea (Camellia sinensis) extracts }\end{array}$ & $2.5 \mathrm{~g} / \mathrm{kg}$ & $4{ }^{\circ} \mathrm{C}$ for 12 days & - & $\begin{array}{c}\text { Inhibitory effect on lipid oxidation; } \\
\text { improved texture of meat; no } \\
\text { influence on colour parameters } \\
\text { and pH }\end{array}$ & [176] \\
\hline $\begin{array}{l}\text { Mechanically } \\
\text { deboned poultry } \\
\text { meat }\end{array}$ & $\begin{array}{l}\text { Rosemary (Rosmarinus officinalis } \\
\text { L.) extracts (dried extract (D), } \\
\text { aqueous extract (WE), } 40 \% \\
\text { ethanol extract (E40), 70\% } \\
\text { ethanol extract (E70), } \\
\text { essential oil (EOS) }\end{array}$ & $\begin{array}{l}20 \mathrm{~g} / \mathrm{kg}(\mathrm{D}, \mathrm{WE}, \mathrm{E} 40 \\
\text { E70) } 2 \mathrm{~g} / \mathrm{kg} \text { (EOS) }\end{array}$ & $\begin{array}{l}\text { Vacuum plastic bags at } \\
-18^{\circ} \mathrm{C} \text { for } 4 \text { months }\end{array}$ & - & $\begin{array}{l}\text { Inhibitory effect on lipid oxidation } \\
\text { and microbial growth (E70, EOS } \\
\text { the most } \\
\text { effective treatments) }\end{array}$ & [177] \\
\hline $\begin{array}{l}\text { Raw and cooked } \\
\text { minced broiler meat }\end{array}$ & $\begin{array}{l}\text { Lemon (Citrus limonum), orange } \\
\text { (C. sinensis) and grapefruit } \\
\text { (C. paradise) seed extracts }\end{array}$ & $15 \mathrm{~g} / \mathrm{kg}$ & Foil paper at $4{ }^{\circ} \mathrm{C}$ for 12 days & - & $\begin{array}{l}\text { Inhibitory effect on lipid oxidation } \\
\text { (in both raw and cooked } \\
\text { meat samples); } \\
\text { antioxidant effect more pronounced } \\
\text { in raw meat samples }\end{array}$ & [178] \\
\hline Raw chicken meat & $\begin{array}{l}\text { Cloves (Syzygium aromaticum, } \\
\text { SA), Chinese cinnamon } \\
\text { (Cinnamomum cassia, CC), } \\
\text { oregano, (Origanum } \\
\text { vulgare; OV), and black mustard } \\
\text { (Brassica nigra, BN) }\end{array}$ & $10 \mathrm{~g} / \mathrm{kg}$ & $\begin{array}{l}\text { Meat aerobically packed in } \\
\text { low-density polyethylene } \\
\text { bags at } 4{ }^{\circ} \mathrm{C} \text { for } 15 \text { days }\end{array}$ & - & $\begin{array}{c}\text { Inhibitory effect on lipid oxidation } \\
\text { (combination of SA, CC and OV: } \\
\text { lowest TBARS values and } \\
\text { higher lightness, } \\
\text { redness and yellowness values); } \\
\text { reduction of microbial growth }\end{array}$ & [179] \\
\hline $\begin{array}{l}\text { Cooked chicken } \\
\text { patties }\end{array}$ & $\begin{array}{l}\text { Pomegranate (Punica granatum) } \\
\text { rind powder (RP) }\end{array}$ & $\begin{array}{l}0.2 \text { g equivalent } R P \\
\text { phenolics } / \mathrm{kg} \text { meat }\end{array}$ & $\begin{array}{l}\text { Patties packaged in LDPE } \\
\text { pouches at } 4{ }^{\circ} \mathrm{C} \text { for } 15 \text { days }\end{array}$ & $\begin{array}{l}441.00 \pm 41.78 \mu \mathrm{g} \\
\mathrm{TAE} / \mathrm{g}(\mathrm{TPC})\end{array}$ & $\begin{array}{l}\text { Inhibitory effect on lipid oxidation } \\
\text { (TBARS values remained low up to } \\
15 \text { days); reduction of lightness } \\
\text { value (chicken patties became } \\
\text { slightly darker) and yellowness } \\
\text { value; no influence on } \\
\text { sensory parameters }\end{array}$ & [180] \\
\hline
\end{tabular}


Table 3. Cont.

\begin{tabular}{|c|c|c|c|c|c|c|}
\hline Product & Source & Dose & Storage Conditions & $\begin{array}{l}\text { Concentration } \\
\text { Product }\end{array}$ & Effect & Reference \\
\hline Chicken meatballs & $\begin{array}{l}\text { Cinnamon (Cinnamomum verum) } \\
\text { deodorized aqueous extract }\end{array}$ & $0.2 \mathrm{~g} / \mathrm{kg}$ & $\begin{array}{l}\text { Meatballs covered with an } \\
\text { oxygen } \\
\text { semi-permeable PVC film } \\
\text { and stored in dark at } \\
8 \pm 1{ }^{\circ} \mathrm{C} \text { for } 12 \text { days }\end{array}$ & - & $\begin{array}{l}\text { Inhibitory effect on lipid oxidation } \\
\text { (decreased TBARS and POV values); } \\
\text { no negative influence on sensory } \\
\text { acceptability; decrease of lightness } \\
\text { value; no influence on redness and } \\
\text { yellowness values }\end{array}$ & [181] \\
\hline Rabbit meat patties & $\begin{array}{c}\text { Fermented rooibos (Aspalathus } \\
\text { linearis) extract }\end{array}$ & $20 \mathrm{~g} / \mathrm{kg}$ & $\begin{array}{c}\text { Patties wrapped with PVC } \\
\text { and stored at } 4 \pm 1^{\circ} \mathrm{C} \text { for } \\
7 \text { days }\end{array}$ & - & $\begin{array}{l}\text { Inhibitory effect on lipid oxidation; } \\
\text { protective action against protein } \\
\text { degradation; reduced SFA content, } \\
\text { no influence on PUFA content; } \\
\text { reduced lightness value, increased } \\
\text { redness and yellowness values; } \\
\text { undesired sensory characteristics } \\
\quad(>0.5 \% \text { level inclusion })\end{array}$ & [183] \\
\hline $\begin{array}{l}\text { Raw and cooked } \\
\text { rabbit burgers }\end{array}$ & $\begin{array}{l}\text { Ginger (Zingiber officinale } \\
\text { Roscoe) powder }\end{array}$ & $20 \mathrm{~g} / \mathrm{kg}$ & $\begin{array}{l}\text { Burgers overwrapped with } \\
\text { polyethylene film and stored } \\
\text { at } 4 \pm 0.5^{\circ} \mathrm{C} \text { for } 7 \text { days }\end{array}$ & - & $\begin{array}{l}\text { Inhibitory effect on lipid oxidation; } \\
\text { improvement of } \\
\text { antioxidant capacity; } \\
\text { increased total PUFA percentage }\end{array}$ & [184] \\
\hline $\begin{array}{l}\text { Fresh and stored } \\
\text { rabbit burgers }\end{array}$ & $\begin{array}{c}\text { Turmeric (Curcuma longa L.) } \\
\text { powder }\end{array}$ & $35 \mathrm{~g} / \mathrm{kg}$ & $\begin{array}{l}\text { Burgers overwrapped with } \\
\text { polyethylene film and stored } \\
\text { at } 4 \pm 0.5^{\circ} \mathrm{C} \text { for } 7 \text { days }\end{array}$ & - & $\begin{array}{c}\text { Improvement of antioxidant } \\
\text { capacity; no influence on lipid } \\
\text { oxidation; reduced yellowness } \\
\text { value; increased PUFA } \\
\text { content }\end{array}$ & [185] \\
\hline
\end{tabular}


Table 3. Cont.

\begin{tabular}{|c|c|c|c|c|c|c|}
\hline Product & Source & Dose & Storage Conditions & $\begin{array}{l}\text { Concentration } \\
\text { Product }\end{array}$ & Effect & Reference \\
\hline $\begin{array}{l}\text { Raw ground pork } \\
\text { meat }\end{array}$ & $\begin{array}{c}\text { Mustard (Brassica juncea) leaf } \\
\text { kimchi extracts }\end{array}$ & $2 \mathrm{~g} / \mathrm{kg}$ & $\begin{array}{c}\text { Anaerobic } \\
\text { polyethylene/Nylon film } \\
\text { bags at } 4 \pm 1^{\circ} \mathrm{C} \text { for } 14 \text { days }\end{array}$ & - & $\begin{array}{l}\text { Inhibitory effect on lipid oxidation; } \\
\text { extension of shelf-life; reduction of } \\
\text { total bacterial count }\end{array}$ & [186] \\
\hline $\begin{array}{l}\text { Raw ground pork } \\
\text { meat }\end{array}$ & $\begin{array}{c}\text { Curry (Murraya koenigii L.), mint } \\
\text { leaves (Mentha spicata) }\end{array}$ & $0.25 \mathrm{~g} / \mathrm{kg}$ & LDPE at $4 \pm 1^{\circ} \mathrm{C}$ for 12 days & - & $\begin{array}{c}\text { Inhibitory effect on lipid oxidation; } \\
\text { reduced pH value at days } 6,9 \text { and } \\
12 \text { of storage; reduced redness and } \\
\text { yellowness values; influence on } \\
\text { colour stability }\end{array}$ & [187] \\
\hline Pork patties & $\begin{array}{c}\text { Rosemary (R. officinalis L.) } \\
\text { extract (RE), tea (TE), grape ( } V \text {. } \\
\text { vinifera) skin extract (GSE) and } \\
\text { coffee (CE) extracts }\end{array}$ & $\begin{array}{l}0.2 \mathrm{~g} / \mathrm{kg} \text { (RE, TE, } \\
\text { GSE) } 0.05 \mathrm{~g} / \mathrm{kg} \text { (CE) }\end{array}$ & $\begin{array}{l}\text { Patties vacuum } \\
\text { packaged at } 4.5^{\circ} \mathrm{C} \text { for } \\
10 \text { days }\end{array}$ & - & $\begin{array}{c}\text { Inhibitory effect on lipid oxidation } \\
\text { (antioxidative efficiency: RE > GSE } \\
>\mathrm{TE}>\mathrm{CE}>\text { control); reduced } \\
\text { hexanal values }\end{array}$ & [188] \\
\hline Cooked pork patties & $\begin{array}{c}\text { Grape (V. vinifera) seed (GS), } \\
\text { water-soluble oregano }(O . \\
\text { vulgare) extract (WS), oleoresin } \\
\text { rosemary (R. officinalis L.) (OR) } \\
\text { extracts }\end{array}$ & $0.2 \mathrm{~g} / \mathrm{kg}$ & $\begin{array}{c}\text { Patties wrapped in PVC at } \\
4{ }^{\circ} \mathrm{C} \text { for } 8 \text { days }\end{array}$ & - & $\begin{array}{c}\text { Inhibitory effect on lipid oxidation } \\
\text { (GS, WS); no influence on TBARS } \\
\text { values (OR); no influence on colour } \\
\text { and pH }\end{array}$ & [189] \\
\hline Cooked sausages & $\begin{array}{l}\text { Cinnamomum zeylanicum } \\
\text { essential oil }\end{array}$ & $0.04 \mathrm{~g} / \mathrm{kg}$ & $4{ }^{\circ} \mathrm{C}$ for 30 days & - & $\begin{array}{l}\text { Inhibitory effect on lipid oxidation } \\
\text { (decreased TBARS and POV } \\
\text { values); no } \\
\text { influence on sensory characteristics }\end{array}$ & [190] \\
\hline Cooked sausages & $\begin{array}{c}\text { Nutmeg (Myristica fragrans) } \\
\text { essential oil }\end{array}$ & $0.020 \mathrm{~g} / \mathrm{kg}$ & $4^{\circ} \mathrm{C}$ for 60 days & - & $\begin{array}{l}\text { Inhibitory effect on lipid oxidation; } \\
\text { reduction of the total number of } \\
\text { aerobic mesophilic bacteria; } \\
\text { improvement of aroma }\end{array}$ & [191] \\
\hline
\end{tabular}


Table 3. Cont.

\begin{tabular}{|c|c|c|c|c|c|c|}
\hline Product & Source & Dose & Storage Conditions & $\begin{array}{l}\text { Concentration } \\
\text { Product }\end{array}$ & Effect & Reference \\
\hline $\begin{array}{l}\text { Raw and cooked } \\
\text { pork patties from } \\
\text { Longissimus dorsi } \\
\text { muscle }\end{array}$ & $\begin{array}{l}\text { Grape seed ( } V \text {. vinifera) extract } \\
\text { (GSE), bearberry (BB) }\end{array}$ & $1 \mathrm{~g} / \mathrm{kg}$ & $\begin{array}{c}\text { MAP (raw pork; } 75 \% \\
\mathrm{O}_{2}: 25 \% \mathrm{CO}_{2} \text { ) at } 4{ }^{\circ} \mathrm{C} \text { for } \\
12 \text { days } \mathrm{MAP}^{2} \text { cooked pork; } \\
75 \% \mathrm{O}_{2}: 25 \% \mathrm{CO}_{2} \text { ) at } 4{ }^{\circ} \mathrm{C} \text { for } \\
4 \text { days }\end{array}$ & - & $\begin{array}{l}\text { Inhibitory effect on lipid oxidation } \\
\text { on day } 9 \text { and } 12 \text { of storage (GSE, BB; } \\
\text { raw pork); inhibitory effect } \\
\text { on TBARS } \\
\text { formation after } 2 \text { and } 4 \text { days of } \\
\text { storage (cooked pork); increase in } \\
\text { redness value of cooked pork (GSE); } \\
\text { no influence on sensory parameters }\end{array}$ & [192] \\
\hline Raw pork patties & $\begin{array}{c}\text { Grape (V. vinifera and V. labrusca } \\
\text { hybrid) seed extract (GRA), } \\
\text { green tea (C. sinensis) extract } \\
\text { (TEA), chestnut (Castanea sativa) } \\
\text { extract (CHE), seaweed (Ulva } \\
\text { lactuca and U. rigida) extract } \\
\text { (SEA) }\end{array}$ & $1 \mathrm{~g} / \mathrm{kg}$ & $\begin{array}{l}\text { Patties packed in } \\
\text { polystyrene trays } \\
\text { sealed with } \\
\text { polyethylene film }(80 \% \\
\mathrm{O}_{2}-20 \% \mathrm{CO}_{2} \text { ) at } 2{ }^{\circ} \mathrm{C} \text { for } \\
20 \text { days }\end{array}$ & - & $\begin{array}{c}\text { Inhibitory effect on lipid } \\
\text { and protein } \\
\text { oxidation (antioxidative efficiency: } \\
\text { GRA > TEA > SEA > CHE); } \\
\text { decreased total } \\
\text { viable count (TEA and GRA: lower } \\
\text { Pseudomonas counts); TEA and GRA: } \\
\text { lower psychotropic aerobic } \\
\text { bacterial counts }\end{array}$ & [193] \\
\hline Salami & $\begin{array}{l}\text { Peanut (Arachis hypogaea L.) } \\
\text { skin extract }\end{array}$ & $1 \mathrm{~g} / \mathrm{kg}$ product & $\begin{array}{l}\text { Salami stored at } 65 \% \text { relative } \\
\text { humidity and } 15^{\circ} \mathrm{C} \text { for } \\
42 \text { days }\end{array}$ & - & $\begin{array}{c}\text { Inhibitory effect on lipid oxidation; } \\
\text { preservative effect of } \\
\text { sensory properties }\end{array}$ & [194] \\
\hline Pork patties & $\begin{array}{l}\text { Black currant (Ribes nigrum L.) } \\
\text { extract (BCE) }\end{array}$ & $20 \mathrm{~g} / \mathrm{kg}$ & $\begin{array}{l}\text { Patties overwrapped in PVC } \\
\text { at } 4{ }^{\circ} \mathrm{C} \text { for } 9 \text { days }\end{array}$ & - & $\begin{array}{c}\text { Inhibitory effect on lipid oxidation } \\
\text { (efficacy of BCE comparable } \\
\text { with BHA); } \\
\text { inhibition of protein oxidation } \\
\text { (decreased carbonyl formation and } \\
\text { increased sulfhydryl groups } \\
\text { content); improved redness value } \\
\text { (patties with BCE displayed } \\
\text { purple colour) }\end{array}$ & [195] \\
\hline
\end{tabular}


Table 3. Cont.

\begin{tabular}{|c|c|c|c|c|c|c|}
\hline Product & Source & Dose & Storage Conditions & $\begin{array}{l}\text { Concentration } \\
\text { Product }\end{array}$ & Effect & Reference \\
\hline Pork patties & $\begin{array}{c}\text { Mugwort (Artemisia princeps } \\
\text { Pamp.), rosemary (R. officinalis } \\
\text { L.) }\end{array}$ & $0.5 \mathrm{~g} / \mathrm{kg}$ & $\begin{array}{l}\text { Patties anaerobically } \\
\text { packaged in PE/nylon film } \\
\text { bags at } 4{ }^{\circ} \mathrm{C} \text { for } 15 \text { days }\end{array}$ & - & $\begin{array}{c}\text { Inhibitory effect on lipid oxidation } \\
\text { (lower primary and secondary } \\
\text { products of lipid oxidation); } \\
\text { decreased chroma values }\end{array}$ & [196] \\
\hline Cooked beef patties & $\begin{array}{c}\text { Grape }(V . \text { vinifera }) \text { seed }(\mathrm{GS}), \\
\text { water-soluble oregano }(\mathrm{O} . \\
\text { vulgare) extract }(\mathrm{WS}), \text { oleoresin } \\
\text { rosemary (R. officinalis L.) (OR) } \\
\text { extracts }\end{array}$ & $0.2 \mathrm{~g} / \mathrm{kg}$ & $\begin{array}{l}\text { Patties wrapped in PVC at } \\
4{ }^{\circ} \mathrm{C} \text { for } 8 \text { days }\end{array}$ & - & $\begin{array}{c}\text { Inhibitory effect on lipid oxidation } \\
\text { (GS, WS); no influence on TBARS } \\
\text { values (OR); no influence on } \\
\text { pH; reduced } \\
\text { visual green discolouration }\end{array}$ & [189] \\
\hline Fresh beef steaks & $\begin{array}{c}\text { Oregano (O. vulgare L.) extract } \\
(\mathrm{OE})\end{array}$ & $\begin{array}{l}40 \mathrm{~g} / \mathrm{kg} \text { (active film } \\
\text { containing OE) } \\
0.4 \mathrm{~mL} / \mathrm{kg} \text { meat } \\
\text { (direct addition of } \\
\text { OE) }\end{array}$ & $\begin{array}{l}\text { Steaks packaged with active } \\
\text { film at } 1^{\circ} \mathrm{C} \text { for } 28 \text { days }\end{array}$ & - & $\begin{array}{c}\text { Inhibitory effect on lipid oxidation; } \\
\text { increase of beef display life from } \\
14 \text { to } 23 \text { days; negative influence } \\
\text { on odour } \\
\text { (unacceptable oregano smell) }\end{array}$ & [197] \\
\hline $\begin{array}{l}\text { Raw and cooked } \\
\text { low-fat beef patties }\end{array}$ & Plum (Prunus domestica) puree & $150 \mathrm{~g} / \mathrm{kg}$ & $\begin{array}{l}\text { Patties wrapped with } \\
\text { polyethylene film at }-18^{\circ} \mathrm{C} \\
\text { for } 45 \text { days }\end{array}$ & - & $\begin{array}{l}\text { Inhibitory effect on lipid oxidation; } \\
\text { decreased lightness value, increased } \\
\text { redness value, decreased } \\
\text { yellowness value (raw samples); no } \\
\text { influence on lightness value, lower } \\
\text { redness value (cooked samples); } \\
\text { increased juiciness and } \\
\text { texture scores }\end{array}$ & [198] \\
\hline Raw beef patties & $\begin{array}{c}\text { Chamnamul (Pimpinella } \\
\text { brachycarpa), fatsia (Aralia elata) } \\
\text { extracts }\end{array}$ & $5 \mathrm{~g} / \mathrm{kg}$ & $\begin{array}{l}\text { Patties placed in Whirl-Pak } \\
\text { bags at } 4{ }^{\circ} \mathrm{C} \text { for } 12 \text { days }\end{array}$ & - & $\begin{array}{c}\text { Inhibitory effect on lipid oxidation; } \\
\text { decreased redness value; } \\
\text { reduction of } \\
\text { final microbial load }\end{array}$ & [199] \\
\hline $\begin{array}{l}\text { Raw and cooked beef } \\
\text { patties }\end{array}$ & Dog rose (Rosa canina L.) extract & $50 \mathrm{~g} / \mathrm{kg}$ & $\begin{array}{l}\text { Patties stored in individual } \\
\text { oxygen-permeable } \\
\text { polyethylene bags at }-18^{\circ} \mathrm{C} \\
\text { for } 20 \text { weeks }\end{array}$ & - & $\begin{array}{l}\text { Inhibitory effect on lipid and } \\
\text { protein } \\
\text { oxidation; higher moisture losses; } \\
\text { increased hardness in patties } \\
\text { subjected to frozen storage }\end{array}$ & [200] \\
\hline
\end{tabular}


Table 3. Cont.

\begin{tabular}{|c|c|c|c|c|c|c|}
\hline Product & Source & Dose & Storage Conditions & $\begin{array}{l}\text { Concentration } \\
\text { Product }\end{array}$ & Effect & Reference \\
\hline Fresh beef patties & $\begin{array}{l}\text { Lyophilized and powdered } \\
\text { Gentiana lutea root }\end{array}$ & $2 \mathrm{~g} / \mathrm{kg}$ & $\begin{array}{l}\text { Patties packaged in MAP } \\
\left(20 \mathrm{O}_{2}: 80 \mathrm{CO}_{2}\right) \text { at } 4 \pm 2{ }^{\circ} \mathrm{C} \\
\text { for } 10 \text { days; Patties packaged } \\
\text { in } \mathrm{MAP}\left(80 \mathrm{O}_{2}: 20 \mathrm{CO}_{2}\right) \text { at } \\
4{ }^{\circ} \mathrm{C} \pm 2{ }^{\circ} \mathrm{C} \text { for } 10 \text { days }\end{array}$ & - & $\begin{array}{l}\text { Inhibitory effect on lipid oxidation; } \\
\text { no influence on pH and microbial } \\
\text { counts; no influence on sensory } \\
\text { attributes (appearance and taste) }\end{array}$ & [201] \\
\hline $\begin{array}{l}\text { Irradiated ground } \\
\text { beef }\end{array}$ & $\begin{array}{c}\text { Marjoram (O. majorana), } \\
\text { rosemary (R. officinalis L.), sage } \\
\text { (Salvia officinalis) }\end{array}$ & $0.4 \mathrm{~g} / \mathrm{kg}$ & $5^{\circ} \mathrm{C}$ & - & $\begin{array}{c}\text { Inhibitory effect on lipid oxidation; } \\
\text { improved colour; decreased } \\
\text { irradiation odour (increased } \\
\text { overall acceptability) }\end{array}$ & [202] \\
\hline $\begin{array}{l}\text { Raw and cooked } \\
\text { ground fresh goat } \\
\text { meat }\end{array}$ & $\begin{array}{l}\text { Green tea }(C \text {. sinensis) extract, } \\
\text { grape }(V . \text { vinifera }) \text { seed extract }\end{array}$ & $6 \mathrm{~g} / \mathrm{kg}$ & $\begin{array}{c}\text { Meat wrapped with } \\
\text { oxygen-permeable PVC at } \\
5^{\circ} \mathrm{C} \text { for } 9 \text { days }\end{array}$ & - & $\begin{array}{l}\text { Inhibitory effect on lipid oxidation; } \\
\text { reduction of redness value }\end{array}$ & [203] \\
\hline Goat meat nuggets & $\begin{array}{l}\text { Broccoli (Brassica oleracea) } \\
\text { powder extract }\end{array}$ & $20 \mathrm{~g} / \mathrm{kg}$ & $\begin{array}{l}\text { Nuggets aerobically } \\
\text { packaged at } 4{ }^{\circ} \mathrm{C}\end{array}$ & $\begin{array}{l}0.16 \pm 0.01 \mathrm{mg} \\
\mathrm{GAE} / \mathrm{g}(\mathrm{TPC})\end{array}$ & $\begin{array}{l}\text { Inhibitory effect on lipid oxidation; } \\
\text { increased meat phenolic content; } \\
\text { decreased pH; decreased } \\
\text { yellowness and chroma values; no } \\
\text { influence on } \\
\text { sensory attributes }\end{array}$ & [204] \\
\hline $\begin{array}{l}\text { Cooked goat meat } \\
\text { patties }\end{array}$ & $\begin{array}{l}\text { Kinnow (Citrus reticulate) rind } \\
\text { powder (KRP), pomegranate } \\
\text { (Punica granatum) rind powder } \\
\text { (PRP) and pomegranate }(P . \\
\text { granatum) seed powder (PSP) }\end{array}$ & $10 \mathrm{~mL}$ & $\begin{array}{c}\text { Patties anaerobically } \\
\text { packaged in LDPE bags at } \\
\quad 4^{\circ} \mathrm{C} \text { for } 12 \text { days }\end{array}$ & $\begin{array}{l}900 \mu \mathrm{g} \text { TAE/g (TPC; } \\
\text { KRP) } 1200 \mu \mathrm{g} \text { TAE/g } \\
\text { (TPC; PRP) } 500 \mu \mathrm{g} \\
\text { TAE/g (TPC; PSP) }\end{array}$ & $\begin{array}{c}\text { Inhibitory effect on lipid oxidation; } \\
\text { (antioxidative efficiency: } \\
\text { PRP > PSP > KRP); increased } \\
\text { lightness value (KRP), } \\
\text { reduced lightness value (PRP); } \\
\text { reduced redness values (PRP, PSP); } \\
\text { decreased yellowness value (PRP); } \\
\text { no influence on sensory evaluation } \\
\text { for colour and } \\
\text { appearance; reduced pH value } \\
(\mathrm{KRP}<\mathrm{PSP}<\mathrm{PRP})\end{array}$ & [205] \\
\hline
\end{tabular}


Table 3. Cont.

\begin{tabular}{|c|c|c|c|c|c|c|}
\hline Product & Source & Dose & Storage Conditions & $\begin{array}{l}\text { Concentration } \\
\text { Product }\end{array}$ & Effect & Reference \\
\hline Goat meat patties & $\begin{array}{l}\text { Chrysanthemum morifolium } \\
\text { flower extract }\end{array}$ & $2 \mathrm{~g} / \mathrm{kg}$ & $\begin{array}{c}\text { Patties labelled at } 4{ }^{\circ} \mathrm{C} \text { for } \\
9 \text { days }\end{array}$ & - & $\begin{array}{c}\text { Inhibitory effect on lipid } \\
\text { and protein } \\
\text { oxidation; no influence on } \\
\text { organoleptic properties } \\
\text { (appearance, flavour, texture, } \\
\text { juiciness, and overall acceptability) }\end{array}$ & [206] \\
\hline $\begin{array}{l}\text { Ground goat meat, } \\
\text { goat meat nuggets }\end{array}$ & $\begin{array}{c}\text { Pomegranate }(P . \text { granatum }) \\
\text { peel extract }\end{array}$ & $10 \mathrm{~g} / \mathrm{kg}$ & $\begin{array}{c}\text { Meat vacuum-packed at } \\
4{ }^{\circ} \mathrm{C} \text { for } 9 \text { days; } \\
\text { Nuggets vacuum-packed at } \\
4{ }^{\circ} \mathrm{C} \text { for } 25 \text { days }\end{array}$ & & $\begin{array}{l}\text { Inhibitory effect on lipid oxidation; } \\
\text { no influence on lightness value; } \\
\text { reduced colour difference; slow } \\
\text { growth of } \\
\text { aerobic plate counts }\end{array}$ & [208] \\
\hline Ground sheep meat & $\begin{array}{c}\text { Sumac (Rhus coriaria L.) water } \\
\text { extract, barberry (Berberis } \\
\text { vulgaris L.) water extract }\end{array}$ & $30 \mathrm{~g} / \mathrm{kg}$ & $\begin{array}{l}\text { Meat stored under aerobic } \\
\text { conditions into polyethylene } \\
\text { bags at } 4^{\circ} \mathrm{C} \text { for } 9 \text { days }\end{array}$ & - & $\begin{array}{l}\text { Inhibitory effect on lipid oxidation; } \\
\text { inhibitory effect of microbial } \\
\text { growth; improvement in } \\
\text { odour score }\end{array}$ & [209] \\
\hline Lamb patties & Olive oil waste extract & $0.4 \mathrm{~g} \mathrm{GAE} / \mathrm{kg}$ muscle & $\begin{array}{c}\text { Patties packaged in MAP } \\
\left(70 \% \mathrm{O}_{2} / 30 \% \mathrm{CO}_{2}\right) \text { at } 4{ }^{\circ} \mathrm{C} \\
\text { for } 9 \text { days }\end{array}$ & - & $\begin{array}{c}\text { Inhibitory effect on lipid } \\
\text { and protein } \\
\text { oxidation; lower fish odour and } \\
\text { flavour, higher odd odour and } \\
\text { flavour; acceptable meat after } \\
6 \text { days of storage }\end{array}$ & [210] \\
\hline Sheep meat nuggets & $\begin{array}{l}\text { Litchi (Litchi chinensis Sonn.) } \\
\text { pericarp extract }\end{array}$ & $15 \mathrm{~g} / \mathrm{kg} \%$ & $\begin{array}{l}\text { Nuggets aerobically packed } \\
\text { in LDPE pouches at } 4{ }^{\circ} \mathrm{C}\end{array}$ & $\begin{array}{l}0.17 \pm 0.01 \mathrm{mg} \\
\mathrm{GAE} / \mathrm{g}(\mathrm{TPC})\end{array}$ & $\begin{array}{l}\text { Inhibitory effect on lipid oxidation; } \\
\text { no influence on sensory attributes }\end{array}$ & [211] \\
\hline $\begin{array}{l}\text { Lamb patties (cooked } \\
\text { and } \\
\text { refrigerated-stored) }\end{array}$ & $\begin{array}{l}\text { Hop (Humulus lupulus L.) } \\
\text { infusion and powder }\end{array}$ & $2 \mathrm{~g} / \mathrm{kg}$ & $\begin{array}{c}\text { Raw: } 4{ }^{\circ} \mathrm{C} \text { for } 7 \text { days; } \\
-18^{\circ} \mathrm{C} \text { for } 90 \text { days; Cooked: } \\
4{ }^{\circ} \mathrm{C} \text { for } 3 \text { days }\end{array}$ & - & $\begin{array}{l}\text { Inhibitory effect on lipid } \\
\text { and protein } \\
\text { oxidation; modification in flavour } \\
\text { acceptance (decreased acceptance of } \\
\text { freshly prepared patties) }\end{array}$ & [212] \\
\hline
\end{tabular}


Table 3. Cont.

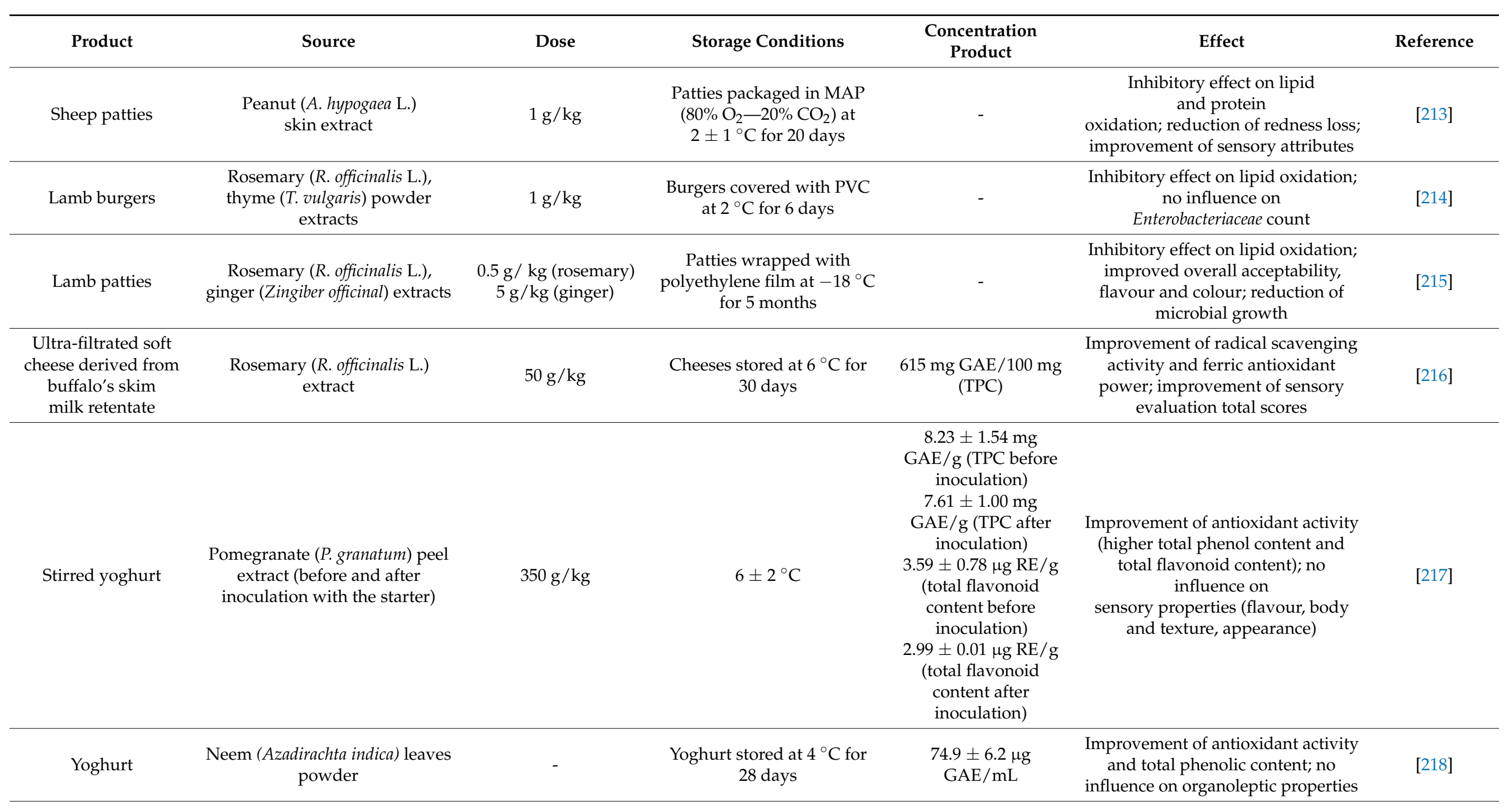


Table 3. Cont.

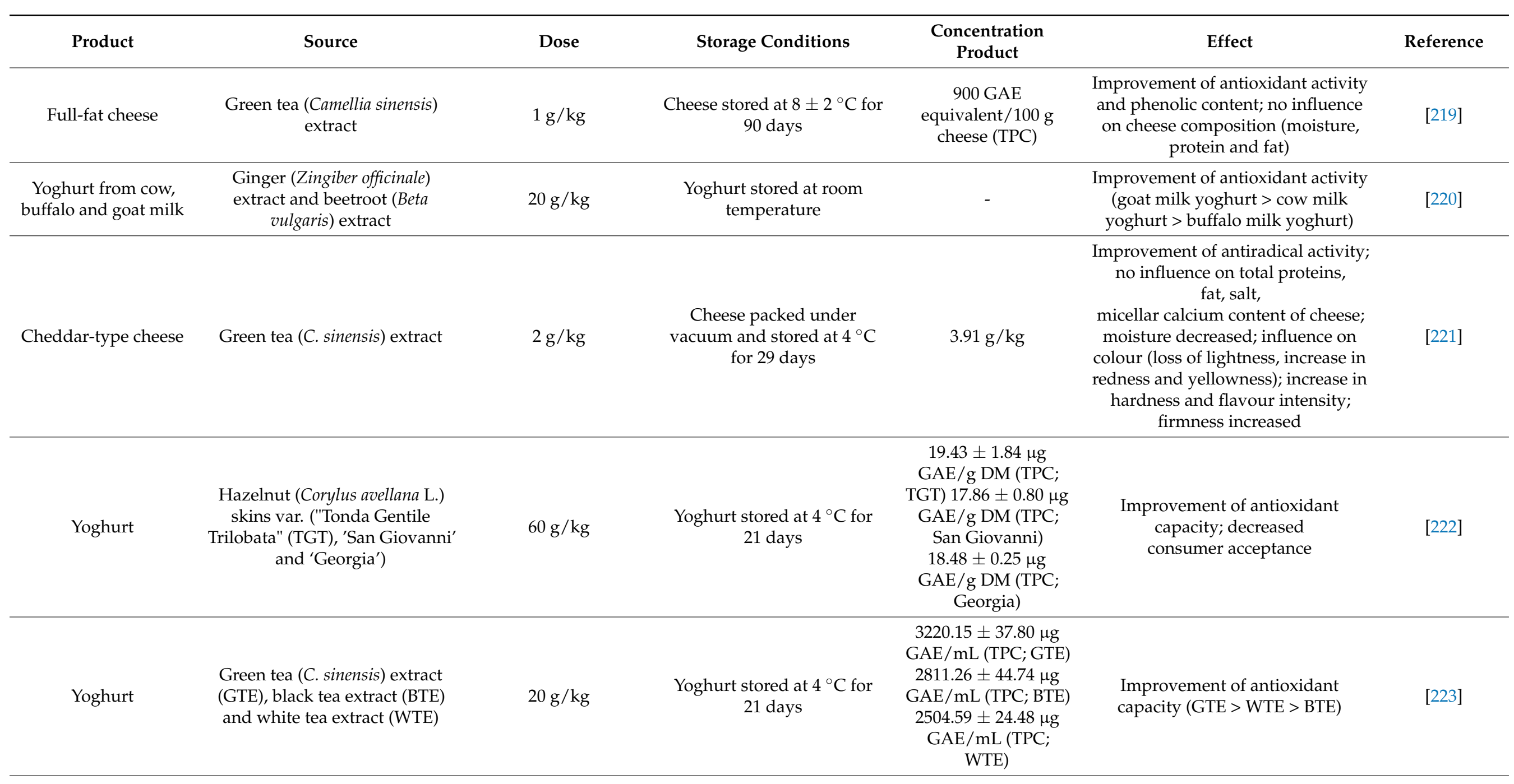


Table 3. Cont.

\begin{tabular}{|c|c|c|c|c|c|c|}
\hline Product & Source & Dose & Storage Conditions & $\begin{array}{l}\text { Concentration } \\
\text { Product }\end{array}$ & Effect & Reference \\
\hline Cow and camel milk & Soybean (Glycine max L.) & - & $\begin{array}{l}\text { Yoghurt stored at } 4{ }^{\circ} \mathrm{C} \text { for } \\
21 \text { days }\end{array}$ & $\begin{array}{c}43.17 \pm 1.2 \mu \mathrm{g} \\
\text { GAE } / \mathrm{g}(\mathrm{TPC} ; \\
\text { cow milk) } \\
91.76 \pm 1.8 \mu \mathrm{g} \\
\text { GAE } / \mathrm{g} \\
\text { (TPC; camel milk) }\end{array}$ & $\begin{array}{c}\text { Improvement of antioxidant activity } \\
\text { (in camel milk); increased } \\
\text { viability of } \\
\text { Lactobacillus spp. }\end{array}$ & [224] \\
\hline Yoghurt & $\begin{array}{l}\text { Chamomile (Matricaria recutita } \\
\text { L.) and fennel (Foeniculum } \\
\text { vulgare Mill.) decoctions }\end{array}$ & $0.4 \mathrm{~g} / \mathrm{kg}$ & $\begin{array}{l}\text { Yoghurt stored at } 4{ }^{\circ} \mathrm{C} \text { for } \\
14 \text { days }\end{array}$ & - & $\begin{array}{l}\text { Improvement of antioxidant activity } \\
\text { (chamomile }>\text { fennel); no influence } \\
\text { on } \mathrm{pH} \text { and colour parameters }\end{array}$ & [225] \\
\hline Ghee & $\begin{array}{c}\text { Coriander (Coriander sativum L.) } \\
\text { extract }\end{array}$ & $5 \mathrm{~g} / \mathrm{kg}$ & $80 \pm 1{ }^{\circ} \mathrm{C}$ for 21 days & - & $\begin{array}{l}\text { Improvement of radical scavenging } \\
\text { activity; inhibition of peroxide and } \\
\text { conjugated dienes formation; } \\
\text { improvement of antioxidant activity }\end{array}$ & [226] \\
\hline Paneer & $\begin{array}{l}\text { Peels of pomegranate }(P . \\
\text { granatum), orange (Citrus } \\
\text { sinensis) and lemon } \\
\text { (C. limonum) }\end{array}$ & $30 \mathrm{~g} / \mathrm{kg}$ & Paneer stored for 8 days & - & $\begin{array}{l}\text { Improvement of antioxidant activity } \\
\text { (prevention of peroxide formation: } \\
\text { pomegranate extract }>\text { lemon } \\
\text { extract }>\text { orange extract) }\end{array}$ & [227] \\
\hline Milk and yoghurt & $\begin{array}{c}\text { Red ginseng (Panax ginseng) } \\
\text { extract }\end{array}$ & $20 \mathrm{~g} / \mathrm{kg}$ & $\begin{array}{l}\text { Milk and yoghurt stored at } \\
\qquad 4{ }^{\circ} \mathrm{C}\end{array}$ & $\begin{array}{c}41.1 \pm 0.9 \mathrm{mg} \text { of } \\
\mathrm{AE} / 100 \mathrm{~g}(\mathrm{TPC} ; \\
\text { yoghurt) } \\
38.3 \pm 0.8 \mathrm{mg} \text { of } \\
\text { GAE } / 100 \mathrm{~g} \\
\text { (TPC; milk) }\end{array}$ & Improvement of antioxidant activity & [228] \\
\hline
\end{tabular}

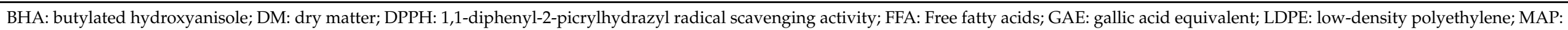

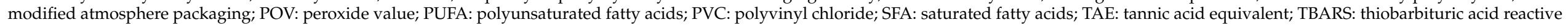
substances; TPC: total phenolic content. 
Concerning beef and beef products, the impact of grape seed extract (GSE) on oxidative stability and shelf-life has been assessed in raw ground beef enriched with omega- 3 fatty acids with $250 \mathrm{mg}$ grape seed extract $/ \mathrm{Kg}$ product during storage at $2{ }^{\circ} \mathrm{C}$ for 6 days under retail display conditions [232]. Grape seed extract supplementation had no significant effect on $\mathrm{pH}$ during the display; this result confirms previous works conducted on the same natural extract added in ground beef $[189,233]$. Conversely, grape seed extract has been shown to decrease the oxidation value, since TBARS values of treatments without GSE increased gradually from $0.57 \mathrm{mg} \mathrm{MDA} / \mathrm{kg}$ to around $3.24 \mathrm{mg} \mathrm{MDA} / \mathrm{kg}$ during display, whereas treatments with GSE had constant TBARS values. The antioxidant activity of grape seed extract, which is directly linked with the presence of phenolic compounds and can delay the formation of TBARS, has been confirmed once again, in agreement with other studies performed in raw and cooked beef [234,235]. It has been reported that the antioxidant activity of this extract is dependent on the concentration from $0.02 \%$ to $0.1 \%$ in cooked ground beef [235]. The results obtained suggest that grape seed extract could represent a technologically viable alternative to stabilize lipid oxidation in beef meat as well.

As mentioned above, rosemary extract represents one of the most popular naturally sourced antioxidants. Its use as an antioxidant started in the 1950s [236] and it has been used in the food industry around the world showing the best protection capacity especially in beef products. The effect of rosemary and oregano extracts, added individually $(400 \mathrm{mg} / \mathrm{kg})$ or in combination $(200 \mathrm{mg} / \mathrm{kg})$, and BHA $/$ BHT, on lipid oxidation and fatty acid composition of irradiated beef burgers stored at $-20^{\circ} \mathrm{C}$ for 90 days has been investigated [237]. Among the natural additives tested, the highest antioxidant capacity was obtained with rosemary extract. In fact, the results of the study showed that rosemary extract, applied alone and in combination with either BHA/BHT or oregano extract, was more effective in maintaining a low oxidation level in the samples than the oregano extract used individually or in combination with BHA/BHT. The average levels of lipid oxidation of beef burger found in this study during storage time and antioxidant capacity of natural extracts such as rosemary and oregano agree with the results of the previous study in which TBARS values were maintained below $2.0 \mathrm{mg} / \mathrm{kg}$ in beef burgers up to 90 days. The results found confirms the great potential to the application of rosemary extract in meat and meat products in replacement of synthetic antioxidants. The combined use of natural extracts and ionizing radiation is recommended to control microbiological and quality changes in beef burger during storage. Interestingly, also in pork products, it has been reported that rosemary extract was more effective than BHA/BHT for preventing increased TBARS values or loss of red colour in frozen pork sausage [238]. Antioxidant activity of $30 \mathrm{mg} / 100 \mathrm{~g}$ rosemary extract has been investigated and compared to BHT, in cooked pork meat patties during 6 days of refrigerated storage at $4 \pm 1{ }^{\circ} \mathrm{C}$ [239]. The patties supplemented with natural extract showed higher redness values than the control and BHT samples, suggesting that the proportion of oxidized myoglobin is lower. The protective effect of this natural extract against discolouration can be ascribed to the high antioxidant activity of polyphenolic compounds present in rosemary extract, which has been reflected in a total polyphenolic content of $3.9 \mathrm{mg} / \mathrm{g}$ in pork patties. Consequently, results showed a significant reduction of TBARS values in batches containing rosemary extract compared to control and BHT samples. These results are in agreement with other studies in which the antioxidant power of rosemary has been demonstrated in meat products such as frozen pork and beef meat [189], refrigerated pork and beef meat [188]. Antioxidant treatment also resulted in lower hexanal content throughout the storage period, showing a higher efficiency against protein oxidation, in comparison with other antioxidants as BHT. Differences in the sensory attributes among batches were not detected by the panel of judges, since aromatic notes that could be attributed to the addition of rosemary extracts caused no negative reactions. The effect of two different levels of rosemary extract $(0.3 \mathrm{~g} / \mathrm{kg}$ and $0.35 \mathrm{~g} / \mathrm{kg})$ on storage stability and quality characteristics of ground chicken meat during storage at $4{ }^{\circ} \mathrm{C}$ for up to 7 days has been evaluated [240]. The antioxidant 
effect of rosemary has been compared with the most popular antioxidant used in the meat industry (Ascorbic acid, Sodium nitrite and BHA). Rosemary has demonstrated to be able to delay lipid oxidation and its effect was comparable to the effect of BHA, with TBARS value significantly lower than the control at day 7 of storage time. Similar with the TBARS results, both Sodium nitrite and rosemary extract $(0.35 \mathrm{~g} / \mathrm{kg})$ showed the highest effect maintaining low total carbonyl values during storage of both cooked and raw meat samples, confirming the ability of rosemary extract to inhibit the formation of aldehydes and protein carbonyls [241,242]. Concerning colour measurements, rosemary extract showed the highest colour stability maintaining redness values compared to the other treatments at day 7 and showed higher lightness values at day 7 compared to the control. Rosemary extract of both levels showed highest significant values of spice odour, but with no ability to distinguish between both levels by the panellists and had a comparable effect on panellist evaluation with Sodium nitrite, which showed the highest overall acceptability. Rosemary at the level of $0.35 \mathrm{~g} / \mathrm{kg}$ could be an excellent natural antioxidant substitution or partial replacement to the synthetic antioxidant used currently in meat preservation.

Dairy products, which are included in the diet of most of the world's population, are also enriched with bioactive compounds from natural sources as a result of consumer demands for healthier and functional foods [243]. As well as meat and meat products, one of the most common problems occurring in dairy products rich in polyunsaturated fatty acids is lipid oxidation and the development of off flavours. The supplementation of phenolic compounds in dairy products may affect their sensory and physicochemical properties, in addition to the antioxidant effect. Some protective delivery systems for food application, such as microencapsulation, can be used to avoid degradation and to camouflage the possible unpleasant taste of the added natural compounds, also increasing the product shelf life [244]. The supplementation of free and microencapsulated polyphenols from olive mill wastewater in Greek-type and European-type sheep's milk yoghurt provided a protective effect that avoided an unwanted drop in the $\mathrm{pH}$ during storage [245]. The addition of rosemary extract, accepted as one of the spices with the highest antioxidant activity, proved useful in preventing lipid oxidation also in dairy products [246]. The influence of the incorporation of a free and microencapsulated rosemary extract has been investigated in cottage cheeses [247]. It was observed that free extract affected the moisture, fat, protein and carbohydrate contents, while the microencapsulated forms did not affect the moisture, fat or protein content but increased the ash content and reduced the carbohydrate content significantly. It was also observed that cheeses with microencapsulated extracts preserved their antioxidant characteristics more efficiently during storage. The application of Inula britannica on Cheddar-type cheese decreased the $\mathrm{pH}$ value and increased the protein and ash contents [248]. In addition, the application of I. britannica was related to an increase in the extract taste, bitterness and extract odour ratings but did not have noticeable effects on the extract odour or acid taste. The effects of the application of dried chestnut (Castanea sativa Mill.) and lemon balm (Melissa officinalis, L.) have been evaluated on Serra da Estrela cheese [249]. The colour measurement revealed that the cheeses enriched with the decoctions of both vegetal samples were slightly darker than the control sample, while the fatty acid profiles showed no significant differences. Higher antioxidant activity was observed in enriched cheeses compared with traditional cheeses.

\section{Conclusions}

In modern farming systems, the main objective is to obtain products of high quality (milk or meat). The concept of quality does not only include a safe product for the consumer, but also the use of farming practices that respect animals' health, either in intensive or extensive systems. It should be apparent from this review that polyphenols play an important, though not always clear, role in the quality of meat and meat products, milk and dairy products. To make a comparison among the studies has not been always possible since about 8000 phenolic compounds have been identified and in different amounts in literature. It cannot be ruled out that different compounds and/or different amounts of polyphenols 
may lead to different results. Anyway, the beneficial effects of plant extracts examined in this review derive mainly from the bioactivities of their polyphenols. The inclusion of these natural extracts in feed rations enhances the oxidative stability of meat and meat products and reduces the number of additives required, like vitamin $\mathrm{E}$ and the other synthetic antioxidants, meeting consumer demands for healthier meat products. Similarly, it has been observed that the direct addition of antioxidants into meat and meat products with these plant rich in polyphenols improve their oxidative stability, the overall sensory and nutritional quality of meat and meat products, and thus their shelf life. However, the optimum dose of inclusion of polyphenols in animal diets is difficult to define due to the different composition of phenolic compounds present in these plants. More studies are needed to determine appropriate doses of these plant extracts to induce beneficial effects minimizing negative ones. Finally, the inclusion of agro-industrial by-products in animal feed could also help to reduce the environmental and economic impact associated with their storage and transformation, representing an innovative and alternative source of antioxidants.

Author Contributions: Conceptualization, V.S., G.P. and G.S.; supervision, G.P.; investigation; V.S. and G.P.; writing—original draft preparation, V.S.; writing—-reviewing and editing, G.P., G.S. and V.S. All authors have read and agreed to the published version of the manuscript.

Funding: This research received no external funding.

Data Availability Statement: All data referred to in the manuscript are already published.

Conflicts of Interest: The authors declare no conflict of interest.

\section{References}

1. Jiang, J.; Xiong, Y. Natural antioxidants as food and feed additives to promote health benefits and quality of meat products: A review. Meat Sci. 2016, 120, 107-117. [CrossRef]

2. Bou, R.; Codony, R.; Tres, A.; Decker, E.A.; Guardiola, F. Dietary strategies to improve nutritional value, oxidative stability, and sensory properties of poultry products. Crit. Rev. Food Sci. Nutr. 2009, 49, 800-822. [CrossRef]

3. Nieto, G.; Estrada, M.; Jordán, M.J.; Garrido, M.D.; Bañón, S. Effects in ewe diet of rosemary by-product on lipid oxidation and the eating quality of cooked lamb under retail display conditions. Food Chem. 2011, 124, 1423-1429. [CrossRef]

4. Lipiński, K.; Mazur, M.; Antoszkiewicz, Z.; Purwin, C. Polyphenols in monogastric nutrition-A review. Ann. Anim. Sci. 2017, 17, 41-58. [CrossRef]

5. Jasiński, M.; Mazurkiewicz, E.; Rodziewicz, P.; Figlerowicz, M. Flawonoidy-budowa, właściwości i funkcja ze szczególnym uwzględnieniem roślin motylkowatych. Biotechnologia 2009, 2, 81-94.

6. Fraga, C.G.; Galleano, M.; Verstraeten, S.V.; Oteiza, P.I. Basic biochemical mechanisms behind the health benefits of polyphenols. Mol. Asp. Med. 2010, 31, 435-445. [CrossRef] [PubMed]

7. Gessner, D.K.; Ringseis, R.; Eder, K. Potential of plant polyphenols to combat oxidative stress and inflammatory processes in farm animals. J. Anim. Physiol. Anim. Nutr. 2016, 101, 605-628. [CrossRef] [PubMed]

8. Landete, J.M. Dietary intake of natural antioxidants: Vitamins and polyphenols. Crit. Rev. Food. Sci. Nutr. 2013, 53, 706-721. [CrossRef]

9. Piluzza, G.; Sulas, L.; Bullitta, S. Tannins in forage plants and their role in animal husbandry and environmental sustainability: A review. Grass Forage Sci. 2014, 69, 32-48. [CrossRef]

10. Scalbert, A.; Morand, C.; Manach, C.; Rémésy, C. Absorption and metabolism of polyphenols in the gut and impact on health. Biomed. Pharmacother. 2002, 56, 276-282. [CrossRef]

11. Petti, S.; Scully, C. Polyphenols, oral health and disease: A review. J. Dent. 2009, 37, 413-423. [CrossRef]

12. Wink, M. Compartmentation of secondary metabolites and xenobiotics in plant vacuoles. Adv. Bot. Res. 1997, 25, 141-169. [CrossRef]

13. Manach, C.; Scalbert, A.; Morand, C.; Rémésy, C.; Jiménez, L. Polyphenols: Food sources and bioavailability. Am. J. Clin. Nutr. 2004, 79, 727-747. [CrossRef]

14. Tangney, C.C.; Rasmussen, H.E. Polyphenols, inflammation, and cardiovascular disease. Curr. Atheroscler. Rep. 2013, 15, 324. [CrossRef] [PubMed]

15. Grassia, M.; Salvatori, G.; Roberti, M.; Planeta, D.; Cinquanta, L. Polyphenols, methylxanthines, fatty acids and minerals in cocoa beans and cocoa products. Food Meas. 2019, 13, 1721-1728. [CrossRef]

16. Rice-Evans, C. Flavonoid antioxidants. Curr. Med. Chem. 2001, 8, 797-807. [CrossRef] 
17. Alcalde-Eon, C.; García-Estévez, I.; Ferreras-Charro, R.; Rivas-Gonzalo, J.C.; Ferrer-Gallego, R.; Escribano-Bailón, M.T. Adding oenological tannin vs. overripe grapes: Effect on the phenolic composition of red wines. J. Food Compos. Anal. 2014, $34,99-113$. [CrossRef]

18. Liang, N.N.; Zhu, B.Q.; Han, S.; Wang, J.H.; Pan, Q.H.; Reeves, M.J.; Duan, C.Q.; He, F. Regional characteristics of anthocyanin and flavonol compounds from grapes of four Vitis vinifera varieties in five wine regions of China. Food Res. Int. 2014, 64, 264-274. [CrossRef]

19. Singh, M.; Kaur, M.; Silakari, O. Flavones: An important scaffold for medicinal chemistry. Eur. J. Med. Chem. 2014, 84, 206-239. [CrossRef]

20. Day, A.J.; Mellon, F.; Barron, D.; Sarrazin, G.; Morgan, M.R.; Williamson, G. Human metabolism of dietary flavonoids: Identification of plasma metabolites of quercetin. Free Radic. Res. 2001, 35, 941-952. [CrossRef] [PubMed]

21. Khan, M.K.; Dangles, O. A comprehensive review on flavanones, the major citrus polyphenols. J. Food Compos. Anal. 2014, 33, 85-104. [CrossRef]

22. Cavalcanti, R.N.; Santos, D.T.; Meireles, M.A.A. Non-thermal stabilization mechanisms of anthocyanins in model and food systems-An overview. Food Res. Int. 2011, 44, 499-509. [CrossRef]

23. Zhang, B.; Deng, Z.; Ramdath, D.D.; Tang, Y.; Chen, P.X.; Liu, R.; Liu, Q.; Tsao, R. Phenolic profiles of 20 Canadian lentil cultivars and their contribution to antioxidant activity and inhibitory effects on $\alpha$-glucosidase and pancreatic lipase. Food Chem. 2015, 172, 862-872. [CrossRef] [PubMed]

24. Zhang, C.; Fu, J.; Wang, Y.; Gao, S.; Du, D.; Wu, F.; Guo, J.; Dong, L. Glucose supply improves petal coloration and anthocyanin biosynthesis in Paeonia suffruticosa 'Luoyang Hong' cut flowers. Postharvest Biol. Technol. 2015, 101, 73-81. [CrossRef]

25. Osorio, C.; Hurtado, N.; Dawid, C.; Hofmann, T.; Heredia-Mira, F.J.; Morales, A.L. Chemical characterisation of anthocyanins in tamarillo (Solanum betaceum Cav.) and Andes berry (Rubus glaucus Benth.) fruits. Food Chem. 2012, 132, 1915-1921. [CrossRef]

26. Reque, P.M.; Steffens, R.S.; Jablonski, A.; Flôres, S.H.; Rios, A.D.O.; de Jong, E.V. Cold storage of blueberry (Vaccinium spp.) fruits and juice: Anthocyanin stability and antioxidant activity. J. Food Compos. Anal. 2014, 33, 111-116. [CrossRef]

27. Castañeda-Ovando, A.; de Lourdes Pacheco-Hernández, M.; Páez-Hernández, M.E.; Rodríguez, J.A.; Galán-Vidal, C.A. Chemical studies of anthocyanins: A review. Food Chem. 2009, 113, 859-871. [CrossRef]

28. Xiao, J.; Cao, H.; Wang, Y.; Zhao, J.; Wei, X. Glycosylation of dietary flavonoids decreases the affinities for plasma protein. J. Agric. Food Chem. 2009, 57, 6642-6648. [CrossRef]

29. Ragin, B.; Akond, M.; Kantartzi, S.; Meksem, K.; Herrera, H.; Akbay, C.; Lightfoot, D.; Kassem, M. Effect of row spacing on seed isoflavone contents in soybean [Glycine max (L.) Merr.]. Am. J. Plant Sci. 2014, 5, 4003-4010. [CrossRef]

30. Balisteiro, D.M.; Rombaldi, C.V.; Genovese, M.I. Protein, isoflavones, trypsin inhibitory and in vitro antioxidant capacities: Comparison among conventionally and organically grown soybeans. Food Res. Int. 2013, 51, 8-14. [CrossRef]

31. Oroian, M.; Escriche, I. Antioxidants: Characterization, natural sources, extraction and analysis. Food Res. Int. 2015, 74, 10-36. [CrossRef] [PubMed]

32. El Gharras, H. Polyphenols: Food sources, properties and applications-A review. Int. J. Food Sci. Technol. 2009, 44, 2512-2518. [CrossRef]

33. Charles, D. Antioxidant Properties of Spices, Herbs and Other Sources; Springer: New York, NY, USA, 2013 ; pp. $65-138$.

34. Chung, K.T.; Wong, T.Y.; Wei, C.I.; Huang, Y.W.; Lin, Y. Tannins and human health: A review. Crit. Rev. Food Sci. Nutr. 1998, 38, 421-464. [CrossRef] [PubMed]

35. Palafox-Carlos, H.; Ayala-Zavala, J.F.; González-Aguilar, G.A. The role of dietary fiber in the bioaccessibility and bioavailability of fruit and vegetable antioxidants. J. Food Sci. 2011, 76, R6-R15. [CrossRef] [PubMed]

36. D'Archivio, M.; Filesi, C.; Di Benedetto, R.; Gargiulo, R.; Giovannini, C.; Masella, R. Polyphenols, dietary sources and bioavailability. Ann. Ist. Super Sanita 2007, 43, 348-361.

37. Brenes, A.; Viveros, A.; Chamorro, S.; Arija, I. Use of polyphenol-rich grape by-products in monogastric nutrition. A review. Anim. Feed. Sci. Tech. 2016, 211, 1-17. [CrossRef]

38. Chiva-Blanch, G.; Visioli, F. Polyphenols and health: Moving beyond antioxidants. J. Berry Res. 2012, 2, 63-71. [CrossRef]

39. Cardona, F.; Andrés-Lacueva, C.; Tulipani, S.; Tinahones, F.J.; Queipo-Ortuño, M.I. Benefits of polyphenols on gut microbiota and implications in human health. J. Nutr. Biochem. 2013, 24, 1415-1422. [CrossRef]

40. Lavefve, L.; Howard, L.R.; Carbon, F. Berry polyphenols metabolism and impact on human gut microbiota and health. Food Funct. 2020, 11, 45-65. [CrossRef]

41. Marín, L.; Miguélez, E.M.; Villar, C.J.; Lombó, F. Bioavailability of dietary polyphenols and gut microbiota metabolism: Antimicrobial properties. BioMed Res. Int. 2015, 905215. [CrossRef] [PubMed]

42. Fotina, A.A.; Fisinin, V.I.; Surai, P.F. Recent developments in usage of natural antioxidants to improve chicken meat production and quality. Bulg. J. Agric. Sci. 2013, 19, 889-896.

43. Surai, P.F. Polyphenol compounds in the chicken/animal diet: From the past to the future. J. Anim. Physiol. Anim. Nutr. 2014, 98, 19-31. [CrossRef] [PubMed]

44. Bieger, J.; Cermak, R.; Blank, R.; de Boer, V.C.; Hollman, P.C.; Kamphues, J.; Wolffram, S. Tissue distribution of quercetin in pigs after long-term dietary supplementation. J. Nutr. 2008, 138, 1417-1420. [CrossRef]

45. Boer de, V.C.; Dihal, A.A.; van der Woude, H.; Arts, I.C.; Wolffram, S.; Alink, G.M.; Hollman, P.C. Tissue distribution of quercetin in rats and pigs. J. Nutr. 2005, 135, 1718-1725. [CrossRef] 
46. Hashemi, S.R.; Davoodi, H. Herbal plants and their derivatives as growth and health promoters in animal nutrition. Vet. Res. Commun. 2011, 35, 169-180. [CrossRef] [PubMed]

47. Paszkiewicz, M.; Budzynska, A.; Rozalska, B.; Sadowska, B. The immunomodulatory role of plant polyphenols. Post. Hig. Med. Dosw. 2012, 66, 637-646. [CrossRef] [PubMed]

48. Kamboh, A.A.; Arain, M.A.; Mughal, M.J.; Zaman, A.; Arain, Z.M.; Soomro, A.H. Flavonoids: Health promoting phytochemicals for animal production-A review. J. Anim. Health Prod. 2015, 3, 6-13. [CrossRef]

49. Berger, L.M.; Wein, S.; Blank, R.; Metges, C.C.; Wolffram, S. Bioavailability of the flavonol quercetin in cows after intraruminal application of quercetin aglycone and rutin. J. Dairy Sci. 2012, 95, 5047-5055. [CrossRef]

50. Lundh, T.J.H.; Pettersson, H.I.; Martinsson, K.A. Comparative levels of free and conjugated plant estrogens in blood plasma of sheep and cattle fed estrogenic silage. J. Agric. Food Chem. 1990, 38, 1530-1534. [CrossRef]

51. Warner, D.; Dijkstra, J.; Hendriks, W.H.; Pellikaan, W.F. Stable isotope-labelled feed nutrients to assess nutrient-specific feed passage kinetics in ruminants. J. Sci. Food Agric. 2014, 94, 819-824. [CrossRef]

52. Gohlke, A.; Ingelmann, C.J.; Nürnberg, G.; Starke, A.; Wolffram, S.; Metges, C.C. Bioavailability of quercetin from its aglycone and its glucorhamnoside rutin in lactating dairy cows after intraduodenal administration. J. Dairy Sci. 2013, 96, 2303-2313. [CrossRef] [PubMed]

53. Höjer, A.; Adler, S.; Purup, S.; Hansen-Møller, J.; Martinsson, K.; Steinshamn, H.; Gustavsson, A.M. Effects of feeding dairy cows different legume-grass silages on milk phytoestrogen concentration. J. Dairy Sci. 2012, 95, 4526-4540. [CrossRef] [PubMed]

54. Cools, S.; Van den Broeck, W.; Vanhaecke, L.; Heyerick, A.; Bossaert, P.; Hostens, M.; Opsomer, G. Feeding soybean meal increases the blood level of isoflavones and reduces the steroidogenic capacity in bovine corpora lutea, without affecting peripheral progesterone concentrations. Anim. Reprod. Sci. 2014, 144, 79-89. [CrossRef]

55. Vasta, V.; Daghio, M.; Cappucci, A.; Buccioni, A.; Serra, A.; Viti, C.; Mele, M. Invited review: Plant polyphenols and rumen microbiota responsible for fatty acid biohydrogenation, fiber digestion, and methane emission: Experimental evidence and methodological approaches. J. Dairy Sci. 2019, 102, 3781-3804. [CrossRef]

56. Rollo, C.D. Growth negatively impacts the life span of mammals. Evol. Dev. 2002, 4, 55-61. [CrossRef]

57. Oriani, G.; Corino, C.; Pastorelli, G.; Pantaleo, L.; Ritieni, A.; Salvatori, G. Oxidative status of plasma and muscle in rabbits supplemented with dietary vitamin E. J. Nutr. Biochem. 2001, 12, 138-143. [CrossRef]

58. Pastorelli, G.; Rossi, R.; Corino, C. Influence of Lippia citriodora verbascoside on growth performance, antioxidant status, and serum immunoglobulins content in piglets. Czech. J. Anim. Sci. 2012, 57, 312-322. [CrossRef]

59. Sies, H. What is oxidative stress? In Oxidative Stress and Vascular Disease; Keaney, J.F., Ed.; Developments in Cardiovascular Medicine; Springer: Boston, MA, USA, 2000; p. 224. [CrossRef]

60. Durand, D.; Damon, M.; Gobert, M. Oxidative stress in farm animals: General aspects. Cah. Nutr. Diet. 2013, 48, 218-224. [CrossRef]

61. Zhong, R.; Zhou, D. Oxidative stress and role of natural plant derived antioxidants in animal reproduction. J. Integr. Agric. 2013, 12, 1826-1838. [CrossRef]

62. Lauridsen, C. From oxidative stress to inflammation: Redox balance and immune system. Poult. Sci. 2019, 98, 4240-4246. [CrossRef]

63. Fiesel, A.; Gessner, D.K.; Most, E.; Eder, K. Effects of dietary polyphenol-rich plant products from grape or hop on proinflammatory gene expression in the intestine, nutrient digestibility and faecal microbiota of weaned pigs. BMC Vet. Res. 2014, 10, 196. [CrossRef] [PubMed]

64. Chen, J.; Li, Y.; Yu, B.; Chen, D.; Mao, X.; Zheng, P.; Luo, J.; He, J. Dietary chlorogenic acid improves growth performance of weaned pigs through maintaining antioxidant capacity and intestinal digestion and absorption function. J. Anim. Sci. 2018, 96, 1108-1118. [CrossRef]

65. Liu, W.C.; Yan, G.; Zhi-Hui, Z.; Rajesh, J.; Balamuralikrishnan, B. Algae-derived polysaccharides promote growth performance by improving antioxidant capacity and intestinal barrier function in broiler chickens. Front. Vet. Sci. 2020, 7, 990. [CrossRef] [PubMed]

66. Al-Kassie, G.A. Influence of two plant extracts derived from thyme and cinnamon on broiler performance. Pak. Vet. J. 2009, 29, 169-173.

67. Jiang, Z.Y.; Jiang, S.Q.; Lin, Y.C.; Xi, P.B.; Yu, D.Q.; Wu, T.X. Effects of soybean isoflavone on growth performance, meat quality, and antioxidation in male broilers. Poult. Sci. 2007, 86, 1356-1362. [CrossRef]

68. Hashemi, S.R.; Davoodi, H. Phytogenics as new class of feed additive in poultry industry. J. Anim. Vet. Adv. 2010, 9, 2295-2304. [CrossRef]

69. Macías-Cruz, U.; Perard, S.; Vicente, R.; Álvarez, F.D.; Torrentera-Olivera, N.G.; González-Ríos, H.; Soto-Navarro, S.A.; Rojo, R.; Meza-Herrera, C.A.; Avendaño-Reyes, L. Effects of free ferulic acid on productive performance, blood metabolites, and carcass characteristics of feedlot finishing ewe lambs. J. Anim. Sci. 2014, 92, 5762-5768. [CrossRef] [PubMed]

70. Valenzuela-Grijalva, N.V.; Pinelli-Saavedra, A.; Muhlia-Almazan, A.; Domínguez-Díaz, D.; González-Ríos, H. Dietary inclusion effects of phytochemicals as growth promoters in animal production. J. Anim. Sci. Technol. 2017, 59, 8. [CrossRef]

71. González-Ríos, H.; Dávila-Ramírez, J.L.; Peña-Ramos, E.A.; Valenzuela-Melendres, M.; Zamorano-García, L.; Islava-Lagarda, T.Y.; Valenzuela-Grijalva, N.V. Dietary supplementation of ferulic acid to steers under commercial feedlot feeding conditions improves meat quality and shelf life. Anim. Feed. Sci. Tech. 2016, 222, 111-121. [CrossRef] 
72. Gladine, C.; Rock, E.; Morand, C.; Cauchart, D.; Durand, D. Bioavailability and antioxidant capacity of plant extracts rich in polyphenols, given as a single acute dose, in sheep made highly susceptible to lipoperoxidation. Br. J. Nutr. 2007, 98, 691-701. [CrossRef]

73. Pastorelli, G.; Rossi, R.; Ratti, S.; Corino, C. Plant extracts in heavy pig feeding: Effects on quality of meat and Cremona salami. Anim. Prod. Sci. 2016, 56, 1199-1207. [CrossRef]

74. Salvatori, G.; Pantaleo, L.; Di Cesare, C.; Maiorano, G.; Filetti, F.; Oriani, G. Fatty acid composition and cholesterol content of muscles as related to genotype and vitamin E treatment in crossbred lambs. Meat Sci. 2004, 67, 45-55. [CrossRef] [PubMed]

75. Corino, C.; Oriani, G.; Pantaleo, L.; Pastorelli, G.; Salvatori, G. Influence of dietary vitamin E supplementation on “heavy” pig carcass characteristics, meat quality, and vitamin E status. J. Anim. Sci. 1999, 77, 1755-1761. [CrossRef]

76. Corino, C.; Pastorelli, G.; Pantaleo, L.; Oriani, G.; Salvatori, G. Improvement of color and lipid stability of rabbit meat by dietary supplementation with vitamin E. Meat Sci. 1999, 52, 285-289. [CrossRef]

77. Wood, J.D.; Richardson, R.I.; Nute, G.R.; Fisher, A.V.; Campo, M.M.; Kasapidou, E.; Sheard, P.R.; Enser, M. Effects of fatty acids on meat quality: A review. Meat Sci. 2004, 66, 21-32. [CrossRef]

78. Falowo, A.B.; Fayemi, P.O.; Muchenje, V. Natural antioxidants against lipid-protein oxidative deterioration in meat and meat products: A review. Food Res. Int. 2014, 64, 171-181. [CrossRef] [PubMed]

79. Pastorelli, G.; Magni, S.; Rossi, R.; Pagliarini, E.; Baldini, P.; Dirinck, P.; Van Opstaele, F.; Corino, C. Influence of dietary fat, on fatty acid composition and sensory properties of dry-cured Parma ham. Meat Sci. 2003, 65, 571. [CrossRef]

80. Gobert, M.; Gruffat, D.; Habeanu, M.; Parafita, E.; Bauchart, D.; Durand, D. Plant extracts combined with vitamin E in PUFA-rich diets of cull cows protect processed beef against lipid oxidation. Meat. Sci. 2010, 85, 676-683. [CrossRef] [PubMed]

81. Jung, S.; Choe, J.H.; Kim, B.; Yun, H.; Kruk, Z.A.; Jo, C. The effect of dietary mixture of gallic acid and linoleic acid on antioxidative potential and quality of breast meat from broilers. Meat Sci. 2010, 86, 520-526. [CrossRef]

82. Dai, F.; Chen, W.F.; Zhou, B. Antioxidant synergism of green tea polyphenols with $\alpha$-tocopherol and l-ascorbic acid in SDS micelles. Biochimie 2008, 90, 1499-1505. [CrossRef]

83. Sáyago-Ayerdi, S.G.; Brenes, A.; Viveros, A.; Goñi, I. Antioxidative effect of dietary grape pomace concentrate on lipid oxidation of chilled and long-term frozen stored chicken patties. Meat Sci. 2009, 83, 528-533. [CrossRef] [PubMed]

84. Goñi, I.; Brenes, A.; Centeno, C.; Viveros, A.; Saura-Calixto, F.; Rebolé, A.; Arija, I.; Estevez, R. Effect of dietary grape pomace and Vitamin E on growth performance, nutrient digestibility, and susceptibility to meat lipid oxidation in chickens. Poult. Sci. 2007, 86, 508-516. [CrossRef]

85. Brenes, A.; Viveros, A.; Goñi, I.; Centeno, C.; Sáyago-Ayerdy, S.G.; Arija, I.; Saura-Calixto, F. Effect of grape pomace concentrate and Vitamin E on digestibility of polyphenols and antioxidant activity in chickens. Poult. Sci. 2008, 87, 307-316. [CrossRef] [PubMed]

86. Aditya, S.; Ohh, S.J.; Ahammed, M.; Lohakare, J. Supplementation of grape pomace (Vitis vinifera) in broiler diets and its effect on growth performance, apparent total tract digestibility of nutrients, blood profile, and meat quality. Anim. Nutr. 2018, 4, 210-214 [CrossRef]

87. Chamorro, S.; Viveros, A.; Rebolé, A.; Rica, B.D.; Arija, I.; Brenes, A. Influence of dietary enzyme addition on polyphenol utilization and meat lipid oxidation of chicks fed grape pomace. Food Res. Int. 2015, 73, 197-203. [CrossRef]

88. Yesilbag, D.; Eren, M.; Agel, H.; Kovanlikaya, A.; Balci, F. Effects of dietary rosemary, rosemary volatile oil and vitamin E on broiler performance, meat quality and serum SOD activity. Br. Poult. Sci. 2011, 52, 472-482. [CrossRef]

89. Marcinčák, S.; Popelka, P.; Nagy, J.; Hussein, K.; Hornanová, L. The impact of Vitamin E and rosemary on the oxidative stability of poultry meat and ground meat products. Folia Vet. 2004, 48, 165-168.

90. Saleh, H.; Golian, A.; Kermanshahi, H.; Mirakzehi, M.T. Antioxidant status and thigh meat quality of broiler chickens fed diet supplemented with $\alpha$-tocopherolacetate, pomegranate pomace and pomegranate pomace extract. Ital. J. Anim. Sci. 2018, 17, 386-395. [CrossRef]

91. Eid, Y.Z.; Ohtsuka, A.; Hayashi, K. Tea polyphenols reduce glucocorticoid- induced growth inhibition and oxidative stress in broiler chickens. Br. Poult. Sci. 2003, 44, 127-132. [CrossRef]

92. Reis, J.H.; Gebert, R.R.; Barreta, M.; Boiago, M.M.; Souza, C.F.; Baldissera, M.D.; Santos, I.D.; Wagner, R.; Laporta, L.V.; Stefani, L.M.; et al. Addition of grape pomace flour in the diet on laying hens in heat stress: Impacts on health and performance as well as the fatty acid profile and total antioxidant capacity in the egg. J. Therm. Biol. 2019, 80, 141-149. [CrossRef]

93. Goliomytis, M.; Kostaki, A.; Avgoulas, G.; Lantzouraki, D.Z.; Siapi, E.; Zoumpoulakis, P.; Simitzis, P.; Deligeorgis, S.G. Dietary supplementation with orange pulp (Citrus sinensis) improves egg yolk oxidative stability in laying hens. Anim. Feed Sci. Tech. 2018, 244, 28-35. [CrossRef]

94. Yan, L.; Kim, I. Effect of dietary grape pomace fermented by Saccharomyces boulardii on the growth performance, nutrient digestibility and meat quality in finishing pigs. Anim. Biosci. 2011, 24, 1763-1770. [CrossRef]

95. O'Grady, M.N.; Carpenter, R.; Lynch, P.B.; O’Brien, N.M.; Kerry, J.P. Addition of grape seed extract and bearberry to porcine diets: Influence on quality attributes of raw and cooked pork. Meat Sci. 2008, 78, 438-446. [CrossRef]

96. Hossain, M.E.; Ko, S.Y.; Yang, C.J. Dietary supplementation of green tea by-products on growth performance, meat quality, blood parameters and immunity in finishing pigs. J. Med. Plants Res. 2012, 6, 2458-2467.

97. Liotta, L.; Chiofalo, B.; Lo Presti, V.; Piccolo, D.; Chiofalo, V.; Chiofalo, V. Rosemary extract (Rosmarinus officinalis L.) supplementation into the diet of Nero Siciliano pigs: Effects on lipid oxidation. Ital. J. Anim. Sci. 2007, 6, 306-308. [CrossRef] 
98. Liotta, L.; Chiofalo, V.; D’Alessandro, E.; Lo Presti, V.; Chiofalo, B. Supplementation of Rosemary extract in the diet of Nero Siciliano pigs: Evaluation of the antioxidant properties on meat quality. Animal 2015, 9, 1065-1072. [CrossRef] [PubMed]

99. Beghelli, D.; de Cosmo, A.; Faeti, V.; Lupidi, G.; Bailetti, L.; Cavallucci, C.; Polidori, P. Origanum vulgare L. and Rosmarinus officinalis L. aqueous extracts in growing-finishing pig nutrition: Effects on antioxidant status, immune responses, polyphenolic content and sensorial properties. J. Food Res. 2018, 8, 90-99. [CrossRef]

100. Larraín, R.; Krueger, C.; Richards, M.; Reed, J. Color changes and lipid oxidation in pork products made from pigs fed with cranberry juice powder. J. Muscle Foods 2008, 19, 17-33. [CrossRef]

101. Zhang, Y.; Li, F.F.; Cao, Y.D.; He, M.L. Supplementation of tea polyphenol mixed with sweetener in diet included with or without flax oil increased antioxidative capacity of blood serum and Longissimus dorsi muscle of fattening pigs. J. Anim. Sci. 2017, 95, 203-204. [CrossRef]

102. Cardinali, R.; Cullere, M.; Dal Bosco, A.; Mugnai, C.; Ruggeri, S.; Mattioli, S.; Castellini, C.; Trabalza Marinucci, M.; Dalle Zotte, A. Oregano, rosemary and vitamin E dietary supplementation in growing rabbits: Effect on growth performance, carcass traits, bone development and meat chemical composition. Livest. Sci. 2015, 175, 83-89. [CrossRef]

103. Dal Bosco, A.; Mourvaki, E.; Cardinali, R.; Servili, M.; Sebastiani, B.; Ruggeri, S.; Mattioli, S.; Taticchi, A.; Esposto, S.; Castellini, C. Effect of dietary supplementation with olive pomaces on the performance and meat quality of growing rabbits. Meat Sci. 2012, 92, 783-788. [CrossRef]

104. Dal Bosco, A.; Gerencsér, Z.; Szendrő, Z.; Mugnai, C.; Cullere, M.; Kovàcs, M.; Ruggeri, S.; Mattioli, S.; Castellini, C.; Dalle Zotte, A. Effect of dietary supplementation of Spirulina (Arthrospira platensis) and Thyme (Thymus vulgaris) on rabbit meat appearance, oxidative stability and fatty acid profile during retail display. Meat Sci. 2014, 96, 114-119. [CrossRef]

105. Dabbou, S.; Gai, F.; Renna, M.; Rotolo, L.; Dabbou, S.; Lussiana, C.; Kovitvadhi, A.; Brugiapaglia, A.; De Marco, M.; Helal, A.N.; et al. Inclusion of bilberry pomace in rabbit diets: Effects on carcass characteristics and meat quality. Meat Sci. 2017, 124, 77-83. [CrossRef]

106. Ianni, A.; Innosa, D.; Martino, C.; Bennato, F.; Martino, G. Compositional characteristics and aromatic profile of caciotta cheese obtained from Friesian cows fed with a dietary supplementation of dried grape pomace. J. Dairy Sci. 2019, 102, $1025-1032$. [CrossRef] [PubMed]

107. Santos, N.W.; Santos, G.T.D.; Silva-Kazama, D.C.; Grande, P.A.; Pintro, P.M.; de Marchi, F.E.; Jobim, C.C.; Petit, H.V. Production, composition and antioxidants in milk of dairy cows fed diets containing soybean oil and grape residue silage. Livest. Sci. 2014, 159, 37-45. [CrossRef]

108. Santos, G.T.; Lima, L.S.; Schogor, A.L.B.; Romero, J.V.; De Marchi, F.E.; Grande, P.A.; Santos, N.W.; Santos, F.S.; Kazama, R. Citrus pulp as a dietary source of antioxidants for lactating Holstein cows fed highly polyunsaturated fatty acid diets. Asian Australas. J. Anim. 2014, 27, 1104-1113. [CrossRef]

109. Cohen-Zinder, M.; Weinberg, Z.; Leibovich, H.; Chen, Y.; Rosen, M.; Sagi, G.; Orlov, A.; Agmon, R.; Yishay, M.; Miron, J.; et al. Ensiled Moringa oleifera: An antioxidant-rich feed that improves dairy cattle performance. J. Agric. Sci. 2017, 155, 1174-1186. [CrossRef]

110. Santos, N.W.; Yoshimura, E.H.; Machado, E.; Matumoto-Pintro, P.T.; Montanher, P.F.; Visentainer, J.V.; dos Santos, G.T.; Zeoula, L.M. Antioxidant effects of a propolis extract and vitamin $\mathrm{E}$ in blood and milk of dairy cows fed diet containing flaxseed oil. Livest. Sci. 2016, 191, 132-138. [CrossRef]

111. O'Grady, M.N.; Maher, M.; Troy, D.J.; Moloney, A.P.; Kerry, J.P. An assessment of dietary supplementation with tea catechins and rosemary extract on the quality of fresh beef. Meat Sci. 2006, 73, 132-143. [CrossRef]

112. Tayengwa, T.; Chikwanha, O.C.; Gouws, P.; Dugan, M.E.R.; Mutsvangwa, T.; Mapiye, C. Dietary citrus pulp and grape pomace as potential natural preservatives for extending beef shelf life. Meat Sci. 2020, 162, 108029. [CrossRef]

113. Branciari, R.; Ranucci, D.; Miraglia, D.; Urbani, S.; Esposto, S.; Servili, M. Effect of dietary treatment with olive oil by-product (olive cake) on physicochemical, sensory and microbial characteristics of beef during storage. Ital. J. Food Saf. 2015, 4, 225-229.

114. Salami, S.A.; O'Grady, M.N.; Luciano, G.; Priolo, A.; McGee, M.; Moloney, A.P.; Kerry, J.P. Quality indices and sensory attributes of beef from steers offered grass silage and a concentrate supplemented with dried citrus pulp. Meat Sci. 2020, $168,108181$. [CrossRef]

115. Boutoial, K.; García, V.; Rovira, S.; Ferrandini, E.; Abdelkhalek, O.; López, M.B. Effect of feeding goats with distilled and non-distilled thyme leaves (Thymus zygis subp. gracilis) on milk and cheese properties. J. Dairy Res. 2013, 80, 448-456. [CrossRef]

116. Delgadillo-Puga, C.; Cuchillo-Hilario, M.; León-Ortiz, L.; Ramírez-Rodríguez, A.; Cabiddu, A.; Navarro-Ocaña, A.; MoralesRomero, A.M.; Medina-Campos, O.N.; Pedraza-Chaverri, J. Goats' feeding supplementation with Acacia farnesiana Pods and their relationship with milk composition: Fatty acids, polyphenols, and antioxidant activity. Animals 2019, 9, 515. [CrossRef]

117. Zhong, R.Z.; Tan, C.Y.; Han, X.F.; Tang, S.X.; Tan, Z.L.; Zeng, B. Effect of dietary tea catechins supplementation in goats on the quality of meat kept under refrigeration. Small Rumin. Res. 2009, 87, 122-125. [CrossRef]

118. Qwele, K.; Hugo, A.; Oyedemi, S.O.; Moyo, B.; Masika, P.J.; Muchenje, V. Chemical composition, fatty acid content and antioxidant potential of meat from goats supplemented with Moringa (Moringa oleifera) leaves, sunflower cake and grass hay. Meat Sci. 2013, 93, 455-462. [CrossRef]

119. Cimmino, R.; Barone, C.M.A.; Claps, S.; Varricchio, E.; Rufrano, D.; Caroprese, M.; Albenzio, M.; De Palo, P.; Campanile, G.; Neglia, G. Effects of dietary supplementation with polyphenols on meat quality in Saanen goat kids. BMC Vet. Res. 2018, 14, 181. [CrossRef] 
120. Branciari, R.; Ranucci, D.; Trabalza-Marinucci, M.; Codini, M.; Orru, M.; Ortenzi, R.; Forte, C.; Ceccarini, M.R.; Valiani, A. Evaluation of the antioxidant properties and oxidative stability of Pecorino cheese made from the raw milk of ewes fed Rosmarinus officinalis L. leaves. Int. J. Food Sci. Technol. 2015, 50, 558-565. [CrossRef]

121. Todaro, M.; Alabiso, M.; Scatassa, M.L.; Di Grigoli, A.; Mazza, F.; Maniaci, G.; Bonanno, A. Effect of the inclusion of fresh lemon pulp in the diet of lactating ewes on the properties of milk and cheese. Anim. Feed Sci. Tech. 2017, 225, 213-223. [CrossRef]

122. Serrano, R.; Jordán, M.J.; Bañó, S. Use of dietary rosemary extract in ewe and lamb to extend the shelf life of raw and cooked meat. Small Rumin. Res. 2014, 116, 144-152. [CrossRef]

123. Bañón, S.; Méndez, L.; Almela, E. Effects of dietary rosemary extract on lamb spoilage under retail display conditions. Meat Sci. 2012, 90, 579-583. [CrossRef]

124. Argov-Argaman, N.; Cohen-Zinder, M.; Leibovich, H.; Yishay, M.; Eitam, H.; Agmon, R.; Hadaya, O.; Mesilati-Stahy, R.; Miron, J.; Shabtay, A. Dietary pomegranate peel improves milk quality of lactating ewes: Emphasis on milk fat globule membrane properties and antioxidative traits. Food Chem. 2020, 313, 125822. [CrossRef]

125. Wang, M.L.; Suo, X.; Gu, J.H.; Zhang, W.W.; Fang, Q.; Wang, X. Influence of grape seed proanthocyanidin extract in broiler chickens: Effect on chicken coccidiosis and antioxidant status. Poult. Sci. 2008, 87, 2273-2280. [CrossRef]

126. Cornescu, G.M.; Panaite, T.D.; Ropota, M.; Olteanu, M.; Soica, C.; Vlaicu, A.; Saracila, M.; Grosu, H. Usage of food industry by products (flaxseed and grapeseed meal) in fattening pigs' diet. Anim. Sci. 2018, 61, 70-76.

127. Macheix, J.J.; Fleuriet, A.; Billot, J. Fruit Phenolics; CRC Press: Boca Raton, FL, USA, 1990; pp. 1-390.

128. Crozier, A. Classification and biosynthesis of secondary plant products: An overview. In Plants: Diet and Health; Goldberg, G., Ed.; Chapman and Hall: London, UK, 2003; pp. 27-48.

129. Saito, M.; Hosoyama, H.; Ariga, T.; Kataoka, S.; Yamaji, N. Antiulcer activity of grape seed extract and procyanidins. J. Agric. Food Chem. 1998, 46, 1460-1464. [CrossRef]

130. Unusan, N. Proanthocyanidins in grape seeds: An updated review of their health benefits and potential uses in the food industry. J. Fuct. Foods 2020, 67, 103861. [CrossRef]

131. Eriz, G.; Sanhueza, V.; Roeckel, M.; Fernández, K. Inhibition of the angiotensin-converting enzyme by grape seed and skin proanthocyanidins extracted from Vitis vinifera L. cv. País. LWT Food Sci. Technol. 2011, 44, 860-865. [CrossRef]

132. Habeanu, M.; Lefter, N.A.; Ropota, M.; Chedea, V.S.; Gheorghe, A.; Toma, S.M.; Ciurescu, G.; Dragomir, C. Dried grape pomace influenced fatty acids composition of Longissimus dorsi muscle and plasma polyphenols spectrum in finishing pigs. Indian J. Anim. Sci. 2015, 85, 786-789.

133. Muñoz-González, I.; Chamorro, S.; Pérez-Jiménez, J.; López-Andrés, P.; Álvarez-Acero, I.; Herrero, A.M.; Nardoia, M.; Brenes, A.; Viveros, A.; Arija, I.; et al. Phenolic metabolites in plasma and thigh meat of chickens supplemented with grape byproducts. J. Agric. Food Chem. 2019, 67, 4463-4471. [CrossRef]

134. Chamorro, S.; Viveros, A.; Rebolé, A.; Arija, I.; Romero, C.; Alvarez, I.; Rey, A.; Brenes, A. Addition of exogenous enzymes to diets containing grape pomace: Effects on intestinal utilization of catechins and antioxidant status of chickens. Food Res. Int. 2017, 96, 226-234. [CrossRef]

135. Mazur-Kuśnirek, M.; Antoszkiewicz, Z.; Lipiński, K.; Kaliniewicz, J.; Kotlarczyk, S.; Żukowski, P. The effect of polyphenols and vitamin $\mathrm{E}$ on the antioxidant status and meat quality of broiler chickens exposed to high temperature. Arch. Anim. Nutr. 2019, 73, 111-126. [CrossRef] [PubMed]

136. Kafantaris, I.; Kotsampasi, B.; Christodoulou, V.; Makri, S.; Stagos, D.; Gerasopoulos, K.; Petrotos, K.; Goulas, P.; Kouretas, D. Effects of dietary grape pomace supplementation on performance, carcass traits and meat quality of lambs. In Vivo 2018, 812, 807-812. [CrossRef]

137. Kara, K.; Kocaoglu-Guclu, B. The effects of different molting methods and supplementation of grape pomace to the diet of molted hens on postmolt performance, egg quality and peroxidation of egg lipids. J. Fac. Vet. Med. Univ. Erciyes 2012, 9, 183-196.

138. Kara, K.; Kocaoğlu Güçlü, B.; Baytok, E.; Şentürk, M. Effects of grape pomace supplementation to laying hen diet on performance, egg quality, egg lipid peroxidation and some biochemical parameters. J. Appl. Anim. Res. 2016, 44, 303-310. [CrossRef]

139. Monagas, M.; Gomez-Cordoves, C.; Bartolome, B.; Laureano, O.; Ricardo da Silva, J. Monomeric, oligomeric, and polymeric flavan-3-ol composition of wines and grapes from Vitis vinifera L. cv. Graciano, Tempranillo, and Cabernet Sauvignon. J. Agric. Food Chem. 2003, 51, 6475-6481. [CrossRef] [PubMed]

140. Francesch, A.; Cartañà, M. The effects of grape seed in the diet of the Penedes chicken, on growth and on the chemical composition and sensory profile of meat. Br. Poult. Sci. 2015, 56, 477-485. [CrossRef]

141. Kaya, A.; Yıldırım, B.A.; Kaya, H.; Gül, M.; Çelebi, S.. The effects of diets supplemented with crushed and extracted grape seed on performance, egg quality parameters, yolk peroxidation and serum traits in laying hens. Eur. Poult. Sci. 2014, 78, 59. [CrossRef]

142. Ke, Z.L.; Pan, Y.; Xu, X.D.; Nie, C.; Zhou, Z.Q. Citrus flavonoids and human cancers. J. Food Nutr. Res. 2015, 3, 341-351. [CrossRef]

143. Yi, L.; Ma, S.; Ren, D. Phytochemistry and bioactivity of Citrus flavonoids: A focus on antioxidant, anti-inflammatory, anticancer and cardiovascular protection activities. Phytochem. Rev. 2017, 16, 479-511. [CrossRef]

144. Manthey, J.A.; Grohmann, K. Phenols in citrus peel by-products. Concentrations of hydroxycinnamates and polymethoxylated flavones in citrus peel molasses. J. Agric. Food Chem. 2001, 49, 3268-3273. [CrossRef]

145. Moset, V.; Piquer, O.; Cervera, C.; Fernández, C.J.; Hernández, P.; Cerisuelo, A. Ensiled citrus pulp as a by-product feedstuff for finishing pigs: Nutritional value and effects on intestinal microflora and carcass quality. Span. J. Agric. Res. 2015, $13,0607$. [CrossRef] 
146. Cerisuelo, A.; Castello, L.; Moset, V.; Martínez, M.; Hernández, P.; Piquer, O.; Gomez, E.; Gasa, J.; Lainez, M. The inclusion of ensiled citrus pulp in diets for growing pigs: Effects on voluntary intake, growth performance, gut microbiology and meat quality. Livest. Sci. 2010, 134, 180-182. [CrossRef]

147. Crosswhite, J.D.; Myers, N.B.; Adesogan, A.T.; Brendemuhl, J.H.; Johnson, D.D.; Carr, C.C. The effect of dietary citrus pulp on the growth, feed efficiency, carcass merit, and lean quality of finishing pigs. Prof. Anim. Sci. 2013, 29, 345-358. [CrossRef]

148. Strong, C.M.; Brendemuhl, J.H.; Johnson, D.D.; Carr, C.C. The effect of elevated dietary citrus pulp on the growth, feed efficiency, carcass merit, and lean quality of finishing pigs. Prof. Anim. Sci. 2015, 31, 191-200. [CrossRef]

149. Mourão, J.L.; Pinheiro, V.M.; Prates, J.A.; Bessa, R.J.B.; Ferreira, L.M.A.; Fontes, C.M.G.A.; Ponte, P.I.P. Effect of dietary dehydrated pasture and citrus pulp on the performance and meat quality of broiler chickens. Poult. Sci. 2008, 87, 733-743. [CrossRef] [PubMed]

150. Rossi, R.; Pastorelli, G.; Cannata, S.; Tavaniello, S.; Maiorano, G.; Corino, C. Effect of long term dietary supplementation with plant extract on carcass characteristics meat quality and oxidative stability in pork. Meat Sci. 2013, 95, 542-548. [CrossRef]

151. Osada, K.; Hoshina, S.; Nakamura, S.; Sugano, M. Cholesterol oxidation in meat products and its regulation by supplementation of sodium nitrite and apple polyphenol before processing. J. Agric. Food Chem. 2000, 48, 3823-3829. [CrossRef]

152. Shan, B.; Cai, Y.Z.; Brooks, J.D.; Corke, H. Antibacterial and antioxidant effects of five spice and herb extracts as natural preservatives of raw pork. J. Sci. Food Agric. 2009, 89, 1879-1885. [CrossRef]

153. Peng, Y.; Yuan, J.; Liu, F.; Ye, J. Determination of active components in rosemary by capillary electrophoresis with electro-chemical detection. J. Pharmaceut. Biomed. 2005, 39, 431-437. [CrossRef] [PubMed]

154. Hölihan, C.M.; Ho, C.T.; Chang, S.S. Elucidation of the chemical structure of a novel antioxidant, rosmaridiphenol, isolated from rosemary. J. Am. Oil Chem. Soc. 1984, 61, 1036-1039. [CrossRef]

155. Bozin, B.; Mimica-Dukic, N.; Samojlik, I.; Jovin, E. Antimicrobial and antioxidant properties of Rosemary and Sage (Rosmarinus officinalis L. and Salvia officinalis L., Laminaceae) essential oils. J. Agric. Food Chem. 2007, 55, 7879-7885. [CrossRef]

156. Gao, M.; Feng, L.; Jiang, T.; Zhu, J.; Fu, L.; Yuan, D.; Li, J. The use of rosemary extract in combination with nisin to extend the shelf life of pompano (Trachinotus ovatus) fillet during chilled storage. Food Control 2014, 37, 1-8. [CrossRef]

157. Olmedo, R.H.; Nepote, V.; Grosso, N.R. Preservation of sensory and chemical properties in flavoured cheese prepared with cream cheese base using oregano and rosemary essential oils. LWT Food Sci. Technol. 2013, 53, 409-417. [CrossRef]

158. Simitzis, P.E.; Symeon, G.K.; Charismiadou, M.A.; Ayoutanti, A.G.; Deligeorgis, S.G. The effects of dietary hesperidin supplementation on broiler performance and chicken meat characteristics. Can. Vet. J. 2011, 91, 275-282. [CrossRef]

159. Benchaar, C.; Chouinard, P.Y. Short communication: Assessment of the potential of cinnamaldehyde, condensed tannins, and saponins to modify milk fatty acid composition of dairy cows. J. Dairy Sci. 2009, 92, 3392-3396. [CrossRef] [PubMed]

160. Moate, P.; Williams, S.; Torok, V.; Hannah, M.; Ribaux, B.; Tavendale, M.; Eckard, R.; Jacobs, J.; Auldist, M.; Wales, W. Grape marc reduces methane emissions when fed to dairy cows. J. Dairy Sci. 2014, 97, 1-15. [CrossRef]

161. Turner, S.A.; Waghorn, G.C.; Woodward, S.L.; Thomson, N.A. Condensed tannins in birdsfoot refoil (Lotus corniculatus) affect the detailed composition of milk from dairy cows. New Zealand Soc. Anim. Prod. 2005, 65, 283-289.

162. Abarghuei, M.J.; Rouzbehan, Y.; Salem, A.Z.M.; Zamiri, M.J. Nitrogen balance, blood metabolites and milk fatty acid composition of dairy cows fed pomegranate-peel extract. Livest. Sci. 2014, 164, 72-80. [CrossRef]

163. Ianni, A.; Di Maio, G.; Pittia, P.; Grotta, L.; Perpetuini, G.; Tofalo, R.; Cichelli, A.; Martino, G. Chemical-nutritional quality and oxidative stability of milk and dairy products obtained from Friesian cows fed with a dietary supplementation of dried grape pomace. J. Sci. Food Agric. 2019, 99, 3635-3643. [CrossRef]

164. Viveros, A.; Chamorro, S.; Pizarro, M.; Arija, I.; Centeno, C.; Brenes, A. Effects of dietary polyphenol-rich grape products on intestinal microflora and gut morphology in broiler chicks. Poult. Sci. 2011, 90, 566-578. [CrossRef]

165. Bennato, F.; Ianni, A.; Innosa, D.; Martino, C.; Grotta, L.; Pomilio, F.; Verna, M.; Martino, G. Influence of licorice root feeding on chemical-nutritional quality of cow milk and Stracciata cheese, an Italian traditional fresh dairy product. Animals 2019, 9, 1153. [CrossRef]

166. Bennato, F.; Ianni, A.; Innosa, D.; Grotta, L.; D’nofrio, A.; Martino, G. Chemical-nutritional characteristics and aromatic profile of milk and related dairy products obtained from goats fed with extruded linseed. Asian-Australas J. Anim. Sci. 2020, 33, 148-156. [CrossRef]

167. Ianni, A.; Martino, G. Dietary grape pomace supplementation in dairy cows: Effect on nutritional quality of milk and its derived dairy products. Foods 2020, 9, 168. [CrossRef]

168. Nudda, A.; Bua, G.; Atzori, A.S.; Cappai, M.G.; Caboni, P.; Fais, G.; Pulina, G. Small amounts of agro-industrial by products in dairy ewes diets affects milk production traits and hematological parameters. Anim. Feed Sci. Technol. 2019, 251, 76-85. [CrossRef]

169. Abbeddou, S.; Rischkowsky, B.; Richter, E.K.; Hess, H.D.; Kreuzer, M. Modification of milk fatty acid composition by feeding forages and agro-industrial byproducts from dry areas to Awassi sheep. J. Dairy Sci. 2011, 94, 4657-4668. [CrossRef]

170. Correddu, F.; Lunesu, M.F.; Buffa, G.; Atzori, A.S.; Nudda, A.; Battacone, G.; Pulina, G. Can agro-industrial by-products rich in polyphenols be advantageously used in the feeding and nutrition of dairy small ruminants? Animals 2020, 10, 131. [CrossRef] [PubMed]

171. Francisco, A.; Alves, S.P.; Portugal, P.V.; Dentinho, M.T.; Jerónimo, E.; Sengo, S.; Almeida, J.; Bressan, M.C.; Pires, V.M.R.; Alfaia, C.M.; et al. Effects of dietary inclusion of citrus pulp and rockrose soft stems and leaves on lamb meat quality and fatty acid composition. Animal 2017, 12, 872-881. [CrossRef] [PubMed] 
172. Zhao, J.X.; Li, Q.; Zhang, R.X.; Liu, W.Z.; Ren, Y.S.; Zhang, C.X.; Zhang, J.X. Effect of dietary grape pomace on growth performance, meat quality and antioxidant activity in ram lambs. Anim. Feed Sci. Technol. 2018, 236, 76-85. [CrossRef]

173. Chaves, A.V.; Dugan, M.E.R.; Stanford, K.; Gibson, L.L.; Bystrom, J.M.; McAllister, T.A.; Van Herk, F.; Benchaar, C. A doseresponse of cinnamaldehyde supplementation on intake, ruminal fermentation, blood metabolites, growth performance, and carcass characteristics of growing lambs. Livest. Sci. 2011, 141, 213-220. [CrossRef]

174. Madsen, H.L.; Bertelsen, G. Spices as antioxidants. Trends Food Sci. Technol. 1995, 6, 271-277. [CrossRef]

175. Saito, M.; Sakagami, H.; Fujisawa, S. Cytotoxicity and apoptosis induction by butylated hydroxyanisole (BHA) and butylated hydroxytoluene (BHT). Anticancer Res. 2003, 23, 4693-4701. [PubMed]

176. Rababah, T.M.; Ereifej, K.I.; Mahasneh, A.A.; Rababah, A.A. Effect of plant extracts on physicochemical properties of chicken breast meat cooked using conventional electric oven or microwave. Poult. Sci. 2006, 85, 148-154. [CrossRef] [PubMed]

177. Hać-Szymanczuk, E.; Cegiełka, A.; Lipinska, E.; Piwowarek, K. Application of rosemary for the prolongation of microbial and oxidative stability in mechanically deboned poultry meat from chickens. Ital. J. Food Sci. 2017, 29, 329-342.

178. Adeyemi, K.D.; Olorunsanya, O.A.; Abe, O.T. Effect of citrus seed extracts on oxidative stability of raw and cooked chicken meat. Ital. J. Appl. Anim. Sci. 2013, 3, 195-199.

179. Radha Krishnan, K.; Babuskin, S.; Azhagu Saravana Babu, P.; Sasikala, M.; Sabina, K.; Archana, G.; Sivarajan, M.; Sukumar, M. Antimicrobial and antioxidant effects of spice extracts on the shelf life extension of raw chicken meat. Int. J. Food Microbiol. 2014, 171, 32-40. [CrossRef] [PubMed]

180. Naveena, B.M.; Sen, A.R.; Kingsly, R.P.; Singh, D.B.; Kondaiah, N. Antioxidant activity of pomegranate rind powder extract in cooked chicken patties. Int. J. Food Sci. Technol. 2008, 43, 1807-1812. [CrossRef]

181. Chan, K.W.; Khong, N.M.H.; Iqbal, S.; Ch'ng, S.E.; Younas, U.; Babji, A.S. Cinnamon bark deodorised aqueous extract as potential natural antioxidant in meat emulsion system: A comparative study with synthetic and natural food antioxidants. J. Food Sci. Technol. 2014, 51, 3269-3276. [CrossRef] [PubMed]

182. Fratianni, F.; De Martino, L.; Melone, A.; De Feo, V.; Coppola, R.; Nazzaro, F. Preservation of chicken breast meat treated with thyme and balm essential oils. J. Food Sci. 2010, 75, M528-M535. [CrossRef] [PubMed]

183. Cullere, M.; Tasoniero, G.; Secci, G.; Parisi, G.; Smit, P.; Hoffman, L.C.; Dalle Zotte, A. Effect of the incorporation of a fermented rooibos (Aspalathus linearis) extract in the manufacturing of rabbit meat patties on their physical, chemical, and sensory quality during refrigerated storage. LWT Food Sci. Technol. 2019, 108, 31-38. [CrossRef]

184. Mancini, S.; Preziuso, G.; Dal Bosco, A.; Roscini, V.; Parisi, G.; Paci, G. Modifications of fatty acids profile, lipid peroxidation and antioxidant capacity in raw and cooked rabbit burgers added with ginger. Meat Sci. 2017, 133, 151-158. [CrossRef]

185. Mancini, S.; Preziuso, G.; Dal Bosco, A.; Roscini, V.; Szendrő, Z.; Fratini, F.; Paci, G. Effect of turmeric powder (Curcuma longa L.) and ascorbic acid on physical characteristics and oxidative status of fresh and stored rabbit burgers. Meat Sci. 2015, 110, 93-100. [CrossRef] [PubMed]

186. Lee, M.A.; Choi, J.H.; Choi, Y.S.; Han, D.J.; Kim, H.Y.; Shim, S.Y.; Chung, H.K.; Kim, C.J. The antioxidative properties of mustard leaf (Brassica juncea) kimchi extracts on refrigerated raw ground pork meat against lipid oxidation. Meat Sci. 2010, 84, 498-504. [CrossRef] [PubMed]

187. Biswas, A.K.; Chatli, M.K.; Sahoo, J. Antioxidant potential of curry (Murraya koenigii L.) and mint (Mentha spicata) leaf extracts and their effect on colour and oxidative stability of raw ground pork meat during refrigeration storage. Food Chem. 2012, 133, 467-472. [CrossRef]

188. Nissen, L.R.; Byrne, D.V.; Bertelsen, G.; Skibsted, L.H. The antioxidative activity of plant extracts in cooked pork patties as evaluated by descriptive sensory profiling and chemical analysis. Meat Sci. 2004, 68, 485-495. [CrossRef] [PubMed]

189. Rojas, M.C.; Brewer, M.S. Effect of natural antioxidants on oxidative stability of cooked, refrigerated beef and pork. J. Food Sci. 2007, 72, S282-S288. [CrossRef] [PubMed]

190. Moarefian, M.; Barzegar, M.; Sattari, M. Cinnamomum zeylanicum essential oil as a natural antioxidant and antibactrial in cooked sausage. J. Food Biochem. 2011, 37, 62-69. [CrossRef]

191. Šojić, B.; Tomović, V.; Kocić-Tanackov, S.; Škaljac, S.; Ikonić, P.; Džinić, N.; Živković, N.; Jokanović, M.; Tasić, T.; Kravić, S. Effect of nutmeg (Myristica fragrans) essential oil on the oxidative and microbial stability of cooked sausage during refrigerated storage. Food Control. 2015, 54, 282-286. [CrossRef]

192. Carpenter, R.; O'Grady, M.N.; O'Callaghan, Y.C.; O’Brien, N.M.; Kerry, J.P. Evaluation of the antioxidant potential of grape seed and bearberry extracts in raw and cooked pork. Meat Sci. 2007, 76, 604-610. [CrossRef]

193. Lorenzo, J.M.; Sineiro, J.; Amado, I.R.; Franco, D. Influence of natural extracts on the shelf life of modified atmosphere-packaged pork patties. Meat Sci. 2014, 96, 526-534. [CrossRef]

194. Larrauri, M.; Barrionuevo, M.G.; Riveros, C.; Mestrallet, M.G.; Zunino, M.P.; Zygadlo, J.A.; Grosso, N.R.; Nepote, V. Effect of peanut skin extract on chemical stability and sensory properties of salami during storage. J. Sci. Food Agric. 2013, 93, 1751-1757. [CrossRef] [PubMed]

195. Jia, N.; Kong, B.; Liu, Q.; Diao, X.; Xia, X. Antioxidant activity of black currant (Ribes nigrum L.) extract and its inhibitory effect on lipid and protein oxidation of pork patties during chilled storage. Meat Sci. 2012, 91, 533-539. [CrossRef]

196. Hwang, K.E.; Kim, H.W.; Song, D.H.; Kim, Y.J.; Ham, Y.K.; Choi, Y.S.; Lee, M.A.; Kim, C.J. Effect of Mugwort and Rosemary either singly, or combination with ascorbic acid on shelf stability of pork patties. J. Food Process. Preserv. 2017, 41, e12994. [CrossRef] 
197. Camo, J.; Lorés, A.; Djenane, D.; Antonio Beltrán, J.; Roncalés, P. Display life of beef packaged with an antioxidant active film as a function of the concentration of oregano extract. Meat Sci. 2011, 88, 174-178. [CrossRef] [PubMed]

198. Y1ldı-Turp, G.; Serdaroglu, M. Effects of using plum puree on some properties of low fat beef patties. Meat Sci. 2010, 86, 896-900. [CrossRef] [PubMed]

199. Kim, S.J.; Cho, A.R.; Han, J. Antioxidant and antimicrobial activities of leafy green vegetable extracts and their applications to meat product preservation. Food Control 2013, 29, 112-120. [CrossRef]

200. Utrera, M.; Morcuende, D.; Ganhão, R.; Estévez, M. Role of phenolics extracting from Rosa canina L. on meat protein oxidation during frozen storage and beef patties processing. Food Bioprocess. Technol. 2015, 8, 854-864. [CrossRef]

201. Azman, N.A.M.; Gordon, M.H.; Skowyra, M.; Segovia, F.; Almajano, M.P. Use of lyophilised and powdered Gentiana lutea root in fresh beef patties stored under different atmospheres. J. Sci. Food Agric. 2015, 95, 1804-1811. [CrossRef]

202. Mohamed, H.M.H.; Mansour, H.A.; Farag, M.D. The use of natural herbal extracts for improving the lipid stability and sensory characteristics of irradiated ground beef. Meat Sci. 2011, 87, 33-39. [CrossRef]

203. Rababah, T.M.; Ereifej, K.I.; Alhamad, M.N.; Al-Qudah, K.M.; Rousan, L.M.; Al-Mahasneh, M.A.; Al-u'datt, M.H.; Yang, W. Effects of green tea and grape seed and TBHQ on physicochemical properties of Baladi goat meats. Int. J. Food Prop. 2011, 14, 1208-1216. [CrossRef]

204. Banerjee, R.; Verma, A.K.; Das, A.K.; Rajkumar, V.; Shewalkar, A.A.; Narkhede, H.P. Antioxidant effects of broccoli powder extract in goat meat nuggets. Meat Sci. 2012, 91, 179-184. [CrossRef]

205. Devatkal, S.K.; Narsaiah, K.; Borah, A. Anti-oxidant effect of extracts of kinnow rind, pomegranate rind and seed powders in cooked goat meat patties. Meat Sci. 2010, 85, 155-159. [CrossRef]

206. Khan, I.A.; Xu, W.; Wang, D.; Yun, A.; Khan, A.; Zongshuai, Z.; Ijaz, M.U.; Yiqun, C.; Hussain, M.; Huang, M. Antioxidant potential of chrysanthemum morifolium flower extract on lipid and protein oxidation in goat meat patties during refrigerated storage. J. Food Sci. 2020, 85, 618-627. [CrossRef]

207. Nassu, R.T.; Gonçalves, L.A.G.; da Silva, M.A.A.P.; Beserra, F.J. Oxidative stability of fermented goat meat sausage with different levels of natural antioxidant. Meat Sci. 2003, 63, 43-49. [CrossRef]

208. Devatkal, S.K.; Thorat, P.; Manjunatha, M. Effect of vacuum packaging and pomegranate peel extract on quality aspects of ground goat meat and nuggets. J. Food Sci. Technol. 2014, 51, 2685-2691. [CrossRef]

209. Aliakbarlu, J.; Mohammadi, S. Effect of sumac and barberry extracts on sheep meat. J. Food Process. Preserv. 2015, 39, 1859-1866. [CrossRef]

210. Muíño, I.; Díaz, M.T.; Apeleo, E.; Pérez-Santaescolástica, C.; Rivas-Cañedo, A.; Pérez, C.; Cañeque, V.; Lauzurica, S.; de la Fuente, J. Valorisation of an extract from olive oil waste as a natural antioxidant for reducing meat waste resulting from oxidative processes. J. Clean. Prod. 2017, 140, 924-932. [CrossRef]

211. Das, A.K.; Rajkumar, V.; Nanda, P.K.; Chauhan, P.; Pradhan, S.R.; Biswas, S. Antioxidant efficacy of litchi (Litchi chinensis Sonn.) pericarp extract in sheep meat nuggets. Antioxidants 2016, 5, 16. [CrossRef] [PubMed]

212. Villalobos-Delgado, L.H.; Caro, I.; Blanco, C.; Bodas, R.; Andrés, S.; Giráldez, F.J.; Mateo, J. Effect of the addition of hop (infusion or powder) on the oxidative stability of lean lamb patties during storage. Small Ruminant Res. 2015, 125, 73-80. [CrossRef]

213. Munekata, P.E.S.; Fernandes, R.P.; Pires de Melo, M.; Trindade, M.A.; Lorenzo, J.M. Influence of peanut skin extract on shelf-life of sheep patties. Asian Pac. J. Trop. Biomed. 2016, 6, 586-596. [CrossRef]

214. Cózar, A.; Linares, M.B.; Garrido, M.D.; Vergara, H. Physicochemical, microbiological quality and oxidative stability in spiced lamb meat burgers. J. Microbiol. Biotechnol. Food Sci. 2013, 3, 217-222.

215. Baker, I.; Alkass, J.E.; Saleh, H. Reduction of oxidative rancidity and microbial activities of the Karadi lamb patties in freezing storage using natural antioxidant extracts of rosemary and ginger. Int. J. Agric. Food Res. 2013, 2, 31-42.

216. El-Din, H.M.F.; Ghita, E.I.; Badran, S.M.A.; Gad, A.S.; El-Said, M.M. Manufacture of low fat UF-soft cheese supplemented with rosemary extract (as natural antioxidant). J. Am. Sci. 2010, 6, 570-579.

217. El-Said, M.M.; Haggag, H.F.; El-Din, H.M.F.; Gad, A.S.; Farahat, A.M. Antioxidant activities and physical properties of stirred yoghurt fortified with pomegranate peel extracts. Ann. Agric. Sci. 2014, 59, 207-212. [CrossRef]

218. Shori, A.B.; Baba, A.S. Antioxidant activity and inhibition of key enzymes linked to type-2 diabetes and hypertension by Azadirachta indica-yogurt. J. Saudi Chem. Soc. 2013, 7, 295-301. [CrossRef]

219. Rashidinejad, A.; Birch, E.J.; David, W. Everett. Antioxidant activity and recovery of green tea catechins in full-fat cheese following gastrointestinal simulated digestion. J. Food Compos. Anal. 2016, 48, 13-24. [CrossRef]

220. Srivastava, P.; Prasad, S.G.M.; Ali, M.N.; Prasad, M. Analysis of antioxidant activity of herbal yoghurt prepared from different milk. Pharma Innov. J. 2015, 4, 18-20.

221. Giroux, H.J.; De Grandpré, G.; Fustier, P.; Champagne, C.P.; St-Gelais, D.; Lacroix, M.; Britten, M. Production and characterization of Cheddar-type cheese enriched with green tea extract. Dairy Sci. Technol. 2013, 93, 241-254. [CrossRef]

222. Bertolino, M.; Belviso, S.; Dal Bello, B.; Ghirardello, D.; Giordano, M.; Rolle, L.; Gerbi, V.; Zeppa, G. Influence of the addition of different hazelnut skins on the physicochemical, antioxidant, polyphenol and sensory properties of yogurt. LWT Food Sci. Technol. 2015, 63, 1145-1154. [CrossRef]

223. Muniandy, P.; Shori, A.B.; Baba, A.S. Influence of green, white and black tea addition on the antioxidant activity of probiotic yogurt during refrigerated storage. Food Pack. Shelf Life 2016, 8, 1-8. [CrossRef] 
224. Shori, A.B. Antioxidant activity and viability of lactic acid bacteria in soybean-yogurt made from cow and camel milk. J. Taibah Univ. Sci. 2013, 7, 202-208. [CrossRef]

225. Caleja, C.; Barros, L.; Antonio, A.L.; Carocho, M.; Oliveira, M.B.P.P.; Ferreira, I.C.F.R. Fortification of yogurts with different antioxidant preservatives: A comparative study between natural and synthetic additives. Food Chem. 2016, 210, 262-268. [CrossRef] [PubMed]

226. Patel, S.; Shende, S.; Arora, S.; Singh, A.K. An assessment of the antioxidant potential of coriander extracts in ghee when stored at high temperature and during deep fat frying. Int. J. Dairy Technol. 2013, 66, 207-213. [CrossRef]

227. Singh, S.; Immanuel, G. Extraction of antioxidants from fruit peels and its utilization in paneer. J. Food Process. Technol. $2014,5,7$. [CrossRef]

228. Park, H.; Lee, M.; Kim, K.T.; Park, E.; Paik, H.D. Antioxidant and antigenotoxic effect of dairy products supplemented with red ginseng extract. J. Dairy Sci. 2018, 101, 8702-8710. [CrossRef] [PubMed]

229. Selani, M.M.; Contreras-Castillo, C.J.; Shirahigue, L.D.; Gallo, C.R.; Plata-Oviedo, M.; Montes-Villanueva, N.D. Wine industry residues extracts as natural antioxidants in raw and cooked chicken meat during frozen storage. Meat Sci. 2011, 88, 397-403. [CrossRef]

230. Brannan, R.G. Effect of grape seed extract on descriptive sensory analysis of ground chicken during refrigerated storage. Meat Sci. 2009, 81, 589-595. [CrossRef]

231. Garrido, M.D.; Auqui, M.; Martí, N.; Linares, M.B. Effect of two different red grape pomace extracts obtained under different extraction systems on meat quality of pork burgers. LWT Food Sci. Technol. 2011, 44, 2238-2243. [CrossRef]

232. Gómez, I.; Beriain, M.J.; Mendizabal, J.A.; Realini, C.; Purroy, A. Shelf life of ground beef enriched with omega-3 and/or conjugated linoleic acid and use of grape seed extract to inhibit lipid oxidation. Food Sci. Nutr. 2016, 4, 67-79. [CrossRef]

233. Bañón, S.; Díaz, P.; Rodríguez, M.; Garrido, M.D.; Price, A. Ascorbate, green tea and grape seed extracts increase the shelf life of low sulphite beef patties. Meat Sci. 2007, 77, 626-633. [CrossRef]

234. Ahn, J.; Grün, I.U.; Mustapha, A. Antimicrobial and antioxidant activities of natural extracts in vitro and in ground beef. J. Food Protect. 2004, 67, 148-155. [CrossRef]

235. Ahn, J.; Grün, I.U.; Fernando, L.N. Antioxidant properties of natural plant extracts containing polyphenolic compounds in cooked ground beef. J. Food Sci. 2002, 67, 1364-1369. [CrossRef]

236. Chipault, J.H.; Mizuno, G.R.; Hawkins, J.M.; Lundberg, W.O. The antioxidant properties of natural spices. J. Food Sci. 1956, 17, 46-55. [CrossRef]

237. Trindade, R.A.; Mancini-Filho, J.; Villavicencio, A.L.C.H. Natural antioxidants protecting irradiated beef burgers from lipid oxidation. LWT Food Sci. Technol. 2010, 43, 98-104. [CrossRef]

238. Sebranek, J.G.; Sewalt, V.J.H.; Robbins, K.L.; Houser, T.A. Comparison of a natural rosemary extract and BHA/BHT for relative antioxidant effectiveness in pork sausage. Meat Sci. 2005, 69, 289-296. [CrossRef] [PubMed]

239. Lara, M.S.; Gutierrez, J.I.; Timón, M.; Andrés, A.I. Evaluation of two natural extracts (Rosmarinus officinalis L. and Melissa officinalis L.) as antioxidants in cooked pork patties packed in MAP. Meat Sci. 2011, 88, 481-488. [CrossRef]

240. Al-Hijazeen, M.; Al-Rawashdeh, M. Preservative effects of rosemary extract (Rosmarinus officinalis L.) on quality and storage stability of chicken meat patties. Food Sci. Technol. 2019, 39, 27-34. [CrossRef]

241. Estévez, M.; Ventanas, S.; Cava, R. Protein oxidation in frankfurters with increasing levels of added rosemary essential oil: Effect on color and texture deterioration. J. Food Sci. 2005, 70, c427-c432. [CrossRef]

242. Jongberg, S.; Torngren, M.A.; Gunvig, A.; Skibsted, L.H.; Lund, M.N. Effect of green tea or rosemary extract on protein oxidation in Bologna type sausages prepared from oxidatively stressed pork. Meat Sci. 2013, 93, 538-546. [CrossRef]

243. Cutrim, C.S.; Cortez, M.A.S. A review on polyphenols: Classification, beneficial effects and their application in dairy products. Int. J. Dairy Technol. 2018, 71, 564-578. [CrossRef]

244. Nazzaro, F.; Orlando, P.; Fratianni, F.; Coppola, R. Microencapsulation in food science and biotechnology. Curr. Opin. Biotechnol. 2012, 23, 182-186. [CrossRef] [PubMed]

245. Petrotos, K.B.; Karkanta, F.K.; Gkoutsidis, P.E.; Giavasis, I.; Papatheodorou, K.N.; Ntontos, A.C. Production of novel bioactive yogurt enriched with olive fruit polyphenols. World Acad. Sci. Eng. Technol. 2012, 64, 867-872.

246. Gad, A.; Sayd, A. Antioxidant properties of Rosemary and its potential uses as natural antioxidant in dairy products-a review. Food Nutr. Sci. 2015, 6, 179-193. [CrossRef]

247. Ribeiro, A.; Caleja, C.; Barros, L.; Santos-Buelga, C.; Barreiro, M.F.; Ferreira, I.C.F.R. Rosemary extracts in functional foods: Extraction, chemical characterization and incorporation of free and microencapsulated forms in cottage cheese. Food Funct. 2016, 7, 2185-2196. [CrossRef] [PubMed]

248. Lee, N.K.; Jeewanthi, R.K.C.; Park, E.H.; Paik, H.D. Physicochemical and antioxidant properties of Cheddar-type cheese fortified with Inula britannica extract. J. Dairy Sci. 2016, 99, 83-88. [CrossRef]

249. Carocho, M.; Barreira, J.C.M.; Antonio, A.L.; Bento, A.; Morales, P.; Ferreira, I.C.F.R. The incorporation of plant materials in “Serra da Estrela" cheese improves antioxidant activity without changing the fatty acid profile and visual appearance. Eur. J. Lipid Sci. Technol. 2015, 117, 1607-1614. [CrossRef] 